\title{
Rethinking Photographic Histories: Indigenous Representation in the Byron Harmon Collection
}

\author{
by \\ Brittany Watson
}

A thesis submitted to the Faculty of Graduate and Postdoctoral Affairs in partial fulfillment of the requirements for the degree of

Master of Arts

in

Art History

Carleton University

Ottawa, Ontario

(C) 2016

Brittany Watson 


\begin{abstract}
Collections of archival photographs have the capacity to provide multiple or alternative histories. In their photographic representations of Indigenous peoples, settler archives can provide a site for revealing the multilayered, fluid meanings. My case study is a group of early twentieth-century photographs (1903 - 1929) depicting members of the Ĩyãhé Nakoda First Nation from the Byron Harmon Photographic collection at the Whyte Museum of the Canadian Rockies. By employing interdisciplinary methodologies with an overarching focus on writing the cultural biography of historical photographs, I perform a self-reflexive interrogation of this collection. I argue for a pluralized examination of historical photographs and photographic archives as a way to create new understandings of the past.
\end{abstract}




\section{Acknowledgments}

I would like to thank all of those who have showed me support, mentorship, and encouragement. I never imagined I would pursue graduate studies and now that I am finishing this journey, you are all on my mind because you saw something in me that I did not. I see it now and I am grateful to have had this opportunity to do this meaningful work. I would like to extend my gratitude to my colleagues at Carleton. Thank you for fostering an environment of trust and support where we could all come together to share our ideas, our feelings, our hard times, and our successes. Your friendship and support has been invaluable to this process. To my supervisor, Dr. Carol Payne, thank you for believing in this project and for helping me to find my voice. I will be forever grateful for your support. You helped me bring this whole thing to fruition in the way I had always intended.

I would like to thank the staff at the Archives \& Library of the Whyte Museum of the Canadian Rockies for all of their help over the years and the knowledge they have shared with me. Thank you to Jennifer Rutkair for your thoughtful comments on this project and your mentorship in the archives that has shaped my passion for collections. Dagny Dubois, I am grateful for our many discussions and your willingness to have me research and work along side you. Thank you to the Harmon family for their openness to this project and a special thanks to Carole Harmon for your wealth of knowledge.

Sebastian, you have been my biggest fan. Thank you for your patience and your encouragement. I do not think I would have survived this whole journey without you. 


\section{Table of Contents}

Abstract................................................................................ii

Acknowledgements...................................................................iii

List of Illustrations................................................................v

Introduction.........................................................................1

1 Chapter One: Photographic Contexts and Byron Harmon..................18

2 Chapter Two: Indigenous Contexts and the Ĩyãhé Nakoda First Nation.....32

3 Chapter Three: Reading the Photographs..................................48

Conclusion........................................................................... 74

Illustrations....................................................................80

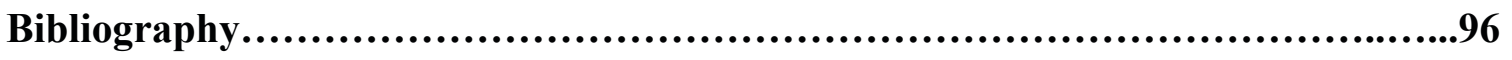




\section{List of Illustrations}

Figure INTRO.1 Byron Harmon, "S08 Grandmother and Child," http://www.byronharmonphotos.com/editions/stoneyLTD/index.html. Last Modified 2013. Used with permission by Carole Harmon.

Figure 1.1 Byron Harmon, "Untitled: [teepees]" [1910], Described as "Site of Banff Springs Hotel golf course," V263/NA-6379, Byron Harmon Fonds, Archives \& Library, Whyte Museum of the Canadian Rockies.

Figure 1.2 Byron Harmon, "Harmon Store," [between 1903 and 1942], V263/NA-4221, Byron Harmon Fonds, Archives \& Library, Whyte Museum of the Canadian Rockies.

Figure 2.1 Byron Harmon, “Lucy Ear,” [ca.1920-1930], V263/NA-3218, Byron Harmon Fonds, Archives \& Library, Whyte Museum of the Canadian Rockies.

Figure 2.2 Byron Harmon, "Indian Days, at Banff Springs Hotel," [ca.1930], V263/NA3353, Byron Harmon Fonds, Archives \& Library, Whyte Museum of the Canadian Rockies.

Figure 2.3 Byron Harmon, "Banff Indian Days race," [ca.1925], V263/NA-3324, Byron Harmon Fonds, Archives \& Library, Whyte Museum of the Canadian Rockies.

Figure 2.4 Byron Harmon, "Banff Indian Days parade," [ca.1910], V263/NA-3362, Byron Harmon Fonds, Archives \& Library, Whyte Museum of the Canadian Rockies.

Figure 3.1 Byron Harmon,"E-22, Banff Indian Days" [ca.1925], V263/NA-3345, "Stoney First Nation, Alma Wildman (sister of Burt Wildman), Elizabeth or Lily (sister of Jimmy Wildman) (future wife of Lazarus Wesley), Paul Poucette (Pa-to-gen)(Pa is head, To is blue, Gen is an endearment)," Byron Harmon Fonds, Archives \& Library, Whyte Museum of the Canadian Rockies.

Figure 3.2 Byron Harmon, "Banff Indian Days," [ca.1925]. V263/NA-3344. "Alma Wildman (sister of Burt Wildman), Elizabeth or Lily (sister of Jimmy Wildman) (future wife of Lazarus Wesley), Paul Poucette (Pa-to-gen)(Pa is head, To is blue, Gen is an endearment)." Byron Harmon Fonds, Archives \& Library, Whyte Museum of the Canadian Rockies.

Figure 3.3 Byron Harmon, "Indian Travois" [ca.1920-1930], V263/NA-3140, Byron Harmon Fonds, Archives \& Library, Whyte Museum of the Canadian Rockies.

Figure 3.4 Byron Harmon, "Indian Travois" [ca.1920-1930], V263/NA-3139, Byron Harmon Fonds, Archives \& Library, Whyte Museum of the Canadian Rockies.

Figure 3.5 Byron Harmon, “Indian Travois," V263/PG-bw-536, Byron Harmon Fonds, Archives \& Library, Whyte Museum of the Canadian Rockies.

Figure 3.6 Byron Harmon, "Indian Travois," V263/PG-bw-536-1, Byron Harmon Fonds, Archives \& Library, Whyte Museum of the Canadian Rockies. 
Figure 3.7 Moore Family Fonds, [Unidentified woman and children with travois], 1899 1927, V439-ps-321 Moore Family Fonds, Archives \& Library, Whyte Museum of the Canadian Rockies.

Figure 3.8 Byron Harmon, S06 Stoney Family and Trava (travois) http://www.byronharmonphotos.com/editions/stoneyLTD/index.html. Last modified 2013. Used with permission by Carole Harmon.

Figure 3.9 Byron Harmon, "506.Stoney Indian and Squaw” [ca.1915-1925], V263/NA3258, Byron Harmon Fonds, Archives \& Library, Whyte Museum of the Canadian Rockies.

Figure 3.10 Byron Harmon, "Stoney Indian and Squaw," V263/PG-bw-506, Byron Harmon Fonds, Archives \& Library, Whyte Museum of the Canadian Rockies.

Figure 3.11 Byron Harmon, "505. Bearskin Indian,” Identified as Joe Stevens, V263/NA-3119, Byron Harmon Fonds, Archives \& Library, Whyte Museum of the Canadian Rockies. 


\section{Introduction}

Biographies of things can make salient what might otherwise remain obscure.

- Igor Kopytoff

A hand-coloured photograph shows an elderly woman seated next to a tipi (Fig. INTRO.1). ${ }^{2}$ She leans forward, right arm crossing her thighs. A folded blanket is draped across her back, over one shoulder, and tucked beneath the other arm. The blanket is thick with stripes running across it with long tassels along the edge. The woman wears a wrinkled shirt; the long sleeves are pulled up at the wrists, unbuttoned. Her legs appear from underneath the skirt, resting at a diagonal. Her face is wrinkled with age, mouth turned down in a frown, and eyes focused on the ground or just below the frame. Wrapped around her head is a scarf tied under her chin. The large knot of the scarf rests on the knot of a kerchief tied around her neck. She leans over to rest her forearm but also to hold the back of a child seated next to her on the ground. The child curls up close to the woman clutching a piece of her skirt and peers almost skeptically out at the camera. The infant wears a hat or bonnet with a fringe framing their face. A striped blanket wraps around them. Moccasins are secured on the child's feet with a hide lace tied in front of their ankle. Behind the pair, the side of a tipi fills the background. Short grass fills the narrow foreground. Below the woman's knee there is what seems to be a stirrup. The hues employed by the hand colouring appear to have been applied to the whole image;

\footnotetext{
${ }^{1}$ Igor Kopytoff, "The Cultural Biography of Things: Commoditization As Process," in The Social Life of Things: Commodities in Cultural Process, ed. Arjun Appadurai (Cambridge: Cambridge University Press, 1976), 67.

2 Byron Harmon, "S08 Grandmother and Child," Stoney Limited Edition Portfolio http://www.byronharmonphotos.com/editions/stoneyLTD/index.html.
} 
from every shadow to each blade of grass has been accented with colour leaving hardly any trace of the original gelatin silver print beneath. The short valley grasses have been given hues of bright green, evergreen, and pale yellow while the grandmother's shirt is light pink, her skirt a muted orange, and her handkerchief a dark blue. The scarf tied around her head is crisp white, the light portion of the blanket tinted beige, and the stripes alternate brown and green. The child's bonnet is a shade of pink-beige, and the clothing is coloured deep blue with light brown accents. Perhaps they are wearing baggy blue jeans or dark blue dress and have covered their shoulders with a striped shawl. Both the older woman and the child's skin has been painted a deep brown. The tipi is tinted a range of colours that resembles stretched canvas that has become worn and dirty from use.

The image I have described above was taken by the photographer Byron Harmon (1876-1942) and is part of a series of hand-coloured photographs depicting Indigenous people—mainly the Ĩyãhé Nakoda people — made between 1903 and 1929. ${ }^{4}$ I first encountered these photographs in person when I travelled to Banff, Alberta, with my now husband to meet his family. His great grandfather happens to be the photographer. I am now a part of this family and I have seen how Harmon's legacy, primarily as a landscape photographer, has unfolded in the town of Banff and beyond. On my first visit to the commercial building the family has owned since 1906, Harmon's photographs of

\footnotetext{
${ }^{3}$ A Note about Language: In this thesis, I adopt terminology that reflects the preferences of the Indigenous peoples discussed. For example, I refer to the Ĩyãhé Nakoda by their self-determined name. They are also commonly known as the Stoney or Stoney Nakoda First Nation. When referring to them or other communities more broadly, I use the term Indigenous. In the instances that I use other terms to refer to Indigenous communities, it is either as a title or caption made before the current acceptable language came into common usage or when directly quoting. "Origin," http://www.rockymountainnakoda.com/, last modified 2015.

4 "Stoney Limited Edition Portfolio," Stoney Limited Edition Portfolio (http://www.byronharmonphotos.com/editions/stoneyLTD/index.html), last Modified 2013, used with permission by Carole Harmon.
} 
mountain views lined the hallways, many of them taken on expeditions or during Alpine Club of Canada climbing camps. ${ }^{5}$ These hand-coloured images were displayed in a small gallery in the building where they sparked my curiosity about the rest of Harmon's work. Seeing them in the small gallery situated within a larger context of photographs that privilege views of explorations into impressive landscapes, I was left with many questions: Who was this photographer and who are the subjects of his images? If he is known for his landscape views and harrowing expeditions, how did he come to photograph Indigenous peoples? Were these photographs sold? How widely did they circulate? Why are they still exhibited? The questions began and so they continue.

After months of research and many more encounters with Harmon's photographs of Indigenous peoples, my perspective on the image of the grandmother and child has changed. Initially, I assumed that the photographs were purely stereotypical representations of Indigenous peoples intended for a tourist consumer market. Their existence made me unconformable as I focused on the representational qualities I had come to think of as only having a capacity for objectification. Thinking in this way, I was disregarding the complex nature of representation and the fluidity of understandings or histories of those photographed despite perceptions of photography as purely objective. I had not considered the full range of how photographic objects function nor did I imagine that the images could assert Indigenous presence.

\footnotetext{
${ }^{5}$ Harmon was predominantly a landscape photographer and his photographs of Indigenous peoples are a small portion of his collection. Harmon was a charter member and official photographer of the Alpine club of Canada. He took part in multiple expeditions into regions of the Rocky Mountains such as the Lake of the Hanging Glaciers, Purcell Mountains and the Bugaboo glacier, a Smithsonian Expedition to the Mount Robson area, among others. One of his most notable expeditions was the Columbia Icefields expedition in 1922. Byron Harmon, Great days in the Rockies: The Photographs of Byron Harmon, 19061934, eds. Carole Harmon and the Peter and Catharine Whyte Foundation (Toronto: Oxford University Press, 1978).
} 
This photograph and others by Harmon exist in the collective memory of the photographer's family, the town of Banff, those associated with Banff National Park, and the Indigenous communities depicted. This thesis addresses the narratives related to the Canadian Rockies or Western Canada as well as a broader story about the representation of Indigenous peoples in Canada. As a student, an archival assistant, and someone close to the family of the photographer, I bear witness to how Harmon's photographs are used, preserved, sold, cherished, and critiqued - personally, in the community, and beyond. Through this lens I propose new ways to engage with and look at the photographic representation of Indigenous peoples.

The history of the Canadian Rockies is often dominated by heroic narratives of settler exploration and discovery in an imagined, conquerable wilderness. Among the gaps in the conventional historical record, photography constitutes an often neglected and misunderstood form of representing the past. Photographs of Indigenous people, for example, are used as a sideline to that master narrative of the Canadian West to authenticate stories of the 'Frontier' or appear as afterthoughts. In this thesis, I propose both a nuanced understanding of histories - pluralized rather than a singular telling of the past - and an emphasis on visual documents in writing and re-writing histories. Photographs — like the one I have described above — can be a starting point for a reexamination of the past. What can images and visual culture tell us? What is revealed in the process of working backwards from a photographic object? What can photographic circulation say about their social or cultural use and reception? 
State of the Literature

Scholarship on the specific subjects addressed in this thesis, particularly on the history of twentieth-century Western Canadian photography, is limited. There is a wealth of critical scholarship on settler photographic representations of Indigenous peoples; however, those studies related to western Canadian experiences are few in number.

Despite the popularity and regional significance of Byron Harmon's photographic oeuvre, to my knowledge no scholarly analysis of his photographs has been published to date. The main secondary source produced specifically on Harmon is Great Days in the Rockies: The Photographs of Byron Harmon, 1906-1934. ${ }^{6}$ Edited by Harmon's granddaughter Carole Harmon, the book features a biography by Bart Robinson, an appreciation by Jon Whyte, and reproductions of select Harmon photographs. The second publication addressing his work is Byron Harmon, Mountain Photographer. ${ }^{7}$ This text is essentially a reprint of Great Days in the Rockies: The photographs of Byron Harmon, 1906-1934 with additional photographs included. My thesis will provide essential critical, academic analyses of specific Harmon photographs, which will fill the scholarly void regarding Harmon's work.

One of the few texts on Western Canadian photography of Indigenous peoples is Brock Silversides's Face Pullers: Photographing Native Canadians 1871-1939. ${ }^{8}$ This book focuses on settler photographers who depicted First Nations peoples living in the southern regions of Saskatchewan and Alberta. Within his survey of prominent

\footnotetext{
${ }^{6}$ Harmon, Great days in the Rockies: The Photographs of Byron Harmon, 1906-1934.

${ }^{7}$ Byron Harmon, Byron Harmon, Mountain Photographer (Banff: Altitude Publishing, 1992).

${ }^{8}$ Brock V. Silversides, Face Pullers: Photographing Native Canadians 1871-1939 (Saskatoon, SK.: Fifth House, 1994).
} 
photographers; Silversides traces links between popular photography and the perpetuation of the 'dying race' narrative. While Silversides provides important historical information, he does not address any photographers in Banff. I will use the foundation developed by Silversides to contextualize Harmon within photographic history in southern Alberta. Silversides is an audio-visual archivist and this publication is a significant contribution to scholarship on Canadian photographic history. Also useful regarding photographers in the Rocky Mountains is This Wild Spirit: Women in the Rocky Mountains of Canada, edited by Colleen Skidmore, a photographic historian. This volume, like Silversides, addresses settler photographic representations of Indigenous subjects, among other themes. Skidmore's volume is particularly useful for comparative information on two prominent female mountain photographers and contemporaries of Harmon, Mary T.S. Schäffer and Mary M. Vaux.

In addition to situating Harmon's work within a Western Canadian frame, I feel that it is important to address his commercial endeavors, particularly as they pertain to marketing of the Indigenous image. Steven D. Hoelscher's Picturing Indians: Photographic Encounters and Tourist Fantasies in H.H. Bennett's Wisconsin Dells ${ }^{9}$ is a valuable case study of a photographer who produced images of Indigenous peoples in proximity to their community for a tourist audience. Like Harmon, H.H. Bennett's photographs of Ho Chunk peoples comprise a small part of his collection; yet these images provide significant records of the complex relationships between a settler photographer and Indigenous sitters.

\footnotetext{
${ }^{9}$ Steven D. Hoelscher, Picturing Indians: Photographic Encounters and Tourist Fantasies in H.H. Bennett's Wisconsin Dells (Madison, Wisconsin: University of Wisconsin Press, 2008).
} 
Amy Lonetree's article “Visualizing Native Survivance: Encounters with my Ho-Chunk Ancestors in the Family Photographs of Charles Van Schaick" has proven particularly valuable to my research. Here, Lonetree offers a scholarly and personal analysis of photographs of her ancestors in the collection of a Minnesota photographer. Drawing on the work of Anishinaabe scholar Gerald Vizenor, Lonetree asserts that photographs of survivors "whose presence in the frame speak to a larger story of HoChunk survivance." 10 This connection is central to my understanding of Harmon's photographs and their significance not only for the decedents of those pictured but also for all other viewers to understand their role in the larger history of the spaces we share in the contemporary moment.

Another important factor in the reading of these photographs is the agency of those photographed. Stephanie Pratt's chapter, "Restating Indigenous Presence in Eastern Dakota and Ho Chunk (Winnebago) Portraits of the 1830s-1860s" from Indigenous Bodies: Reviewing, Relocating, Reclaiming is a valuable source for examining how Indigenous subjects subvert the authority of the western portrait. ${ }^{11}$ Similarly, in Framing the West: Race, Gender, and the Photographic Frontier in the Pacific Northwest, Carol Williams refutes assumptions that Indigenous peoples were not eager to participate in photographic exchanges. Instead, she argues that photography was "an active negotiation

${ }^{10}$ Amy Lonetree, "Visual Native Survivance: Encounters with My Ho-Chunk Ancestors in the Family Photographs of Charles Van Schaick," in People of the Big Voice: Photographs of Ho-Chunk Families by Charles Van Schaick, 1879-1942, eds. Tom Jones, Michael Schmudlach, Matthew Daniel Mason, Amy Lonetree, \& George A. Greendeer (Madison, Wisconsin: Wisconsin Historical Society Press, 2011), 22.

${ }^{11}$ Stephanie Pratt, "Restating Indigenous Presence in Eastern Dakota and Ho Chunk (Winnebago) Portraits of the 1830s-1860s," In Indigenous Bodies: Reviewing, Relocating, Reclaiming, ed. Jaqueline Fear-Segal and Rebecca Tillet (Albany: State University of New York Press, 2013) 21. 
rather than a mechanical process resulting in an artifact." ${ }^{\prime 2}$ Pratt's and Williams' texts will be integral to reflecting the complex relationship between the settler photographer and Indigenous subjects.

Publications pertaining to the historical context of Indigenous groups on the plains and foothills of the Rocky Mountains have also been useful to my research. They provide historical context for a period of Canadian history that has until recently been dominated by stories of progress and success while erasing histories of subjugation and colonialism. Key among them are James Daschuk's Clearing the Plains: Disease, Politics of Starvation, and the Loss of Aboriginal Life $e^{13}$ and The True Spirit and Original Intent of Treaty 7 " by Treaty 7 Elders and Tribal Council members. ${ }^{14}$ Clearing the Plains is a critical history of the effects of colonialism on the peoples of the plains. For the purpose of this thesis, Daschuk's text is a valuable source for studying the intricacies of how treaties and government control was enacted. The True Spirit and Original Intent of Treaty 7 gives historical information regarding the history of Treaty 7 communities, which included the Ĩyãhé Nakoda as signatories. This volume, comprising oral histories recorded with the elders of the communities, provides important Indigenous perspectives. It also critically analyses the process of treaty signing and provides accounts of the experiences and inter-generational effects of the treaties on communities that are not usually a part of governmental records.

\footnotetext{
${ }^{12}$ Carol Williams, Framing the West: Race, Gender, and the Photographic Frontier in the Pacific Northwest (New York: Oxford University Press, 2003) 139.

13 James Daschuk, Clearing the Plains: Disease, Politics of Starvation, and Loss of Aboriginal Life (Regina, Saskatchewan: University of Regina Press, 2013).

${ }^{14}$ Hildebrant et al., The True Spirit and Original Intent of Treaty 7 (Montreal: McGill-Queen's University Press, 1996).
} 
There are also a number of popular books about Indigenous peoples of the Rocky Mountains, which I have consulted. These publications, including Indians of the Rocky Mountain Parks ${ }^{15}$ by Hugh Dempsey, are written exclusively from settler perspectives. Similarly, Jon Whyte's Indians in the Rockies may also be considered a popular text for the history of Indigenous people of the area; however, it is not an anthropological or ethnographic text but rather what he calls an 'informal history' of the Indigenous communities of the area. ${ }^{16}$ Indian Tribes of the Northern Rockies ${ }^{17}$ by Adolf and Beverly Hungry Wolf, while written by a team with one Indigenous author (Beverly Hungry Wolf ), the chapter pertaining the Ĩyãhé Nakoda is largely sourced from anthropological texts. In contrast, I have chosen to privilege the words of the Elders themselves from the interviews found in The True Spirit and Original Intent of Treaty 7; therefore, texts by Dempsey and Whyte will be employed for context on settler perspectives.

Important to my discussion of photographs is Indigenous participation in Banff Indian Days, which was an annual festival, hosted as a spectacle for tourists at Banff National Park. The most recent text addressing this event is Spirits of the Rockies: Reasserting an Indigenous Presence in Banff National Park ${ }^{18}$ by Courtney Mason. The book is the result of six years of ethnographic research and draws on oral testimonies of elders as well as the examination of archival records. This text is important to my thesis and my understanding of the festival and how it functioned in the community and how it was organized.

\footnotetext{
${ }^{15}$ Hugh Dempsey, Indians of the Rocky Mountain Parks (Calgary: Fifth House Publishers, 1998).

${ }^{16}$ Jon Whyte, Indians in the Rockies (Banff: Altitude Publishing, 1985).

${ }^{17}$ Adolf and Beverly Hungry Wolf, Indian Tribes of the Northern Rockies (Skookumchuck: Good Medicine Books, 1989).

${ }^{18}$ Courtney W. Mason, Spirits of the Rockies: Reasserting an Indigenous Presence in Banff National Park (Toronto: University of Toronto Press, 2014).
} 


\section{Methodology}

Scholarship on historical photographs_-including those depicting Indigenous peoples - has until recently been dominated by theories of representation. In this thesis, I argue that focusing on only the visual aspects of historical photographs will not provide the necessary multidimensional, critical reading of photographic objects. Through a selfreflexive interrogation of historical photographs, archival practices, and both historical and archival narrative formations, this thesis seeks to uncover the fluid nature of photographic histories.

My analyses of photographs from the Byron Harmon fonds are performed and presented through various interdisciplinary methodological lenses. In an effort to discuss the images without creating a monolithic research outcome, I will examine these photographs through a series of multi-layered readings. Informing my readings of the photographs are considerations of the visual aspects found in the image, the material lives of the photographs, the archival narrative, and the social and political contexts of their creation.

Through this multifocal approach, I demonstrate that these photographsdepicting Indigenous peoples and made by a settler photographer-have diverse material lives, complex archival afterlives, and potentially important cultural meaning to Indigenous communities today. In this work, I am attempting to bring historical photographs into a contemporary, critical context and away from readings that locate Indigenous histories in a static, ahistorical past. The material products of difficult histories can be re-contextualized in ways that subvert common narratives of Indigenous 
representation and presence in Canada. I have attempted to work against historical academic notions that the researcher or writer is omniscient, detached, and holds the sole authority over knowledge production. By taking a multivalent and open-ended approach to the writing of a history of photographs, I am refusing to assert my authority as the one and only voice. This thesis attempts to transparently present the knowledge that the opinions and views held within are solely based on my subjectivity. My knowledge base position in Canadian settler society, educational background, professional experience, and personal proximity to the Harmon family, all inform my views. Therefore, I neither purport to speak for another person or community nor suggest that my readings of the photographs and the contextual histories more important than those of the Indigenous communities the photographs depict. Further, my approach to this fonds also decentres the photographer from a place of sole authority over photographic meaning. Instead, Byron Harmon becomes a part of the matrix of the "cultural biography" of the photographs. The Harmon family, museum personnel who work with the photographer's fonds, and I also have become a part of the cultural biography and are all implicated in what that means in the contemporary moment.

Part of my self-reflexive approach appears here in the form of first person narrative. Writing in this way allows me to include my own voice and makes explicit my interaction with the fonds. Since the subject matter is close to me, personally, I feel this is an ideal way to interrogate the photographs: as a form of ethical, self-reflexive settler engagement. ${ }^{19}$

${ }^{19}$ I see this thesis as part of a larger future project that includes engagement with and commentary from the Ĩyãhé Nakoda communities. 
As indicated above, the overarching method adopted within is the "cultural biography" of objects. Scholar Igor Kopytoff developed this model in the influential 1986 essay "The Cultural Biography of Things: Commoditization as Process." ${ }^{20}$ An investigation into a history or biography of objects - including the photographic objectwith attention to their social, political, and economic context (past or present) can reveal histories of people, places, objects, collections, etc. that otherwise remain unseen. As Kopytoff states, "a culturally informed economic biography of an object would look at it as a culturally constructed entity, endowed with culturally specific meanings, and classified and reclassified into culturally constituted categories." ${ }^{21}$ Although Kopytoff provides a general approach to this study, Elizabeth Edwards offers a more nuanced application of cultural biography methodology to the specific study of photographs. In the article "Objects of Affect: Photography Beyond the Photographic Image,",2 Edwards cautions that while Kopytoff's approach is useful, alone it remains too linear for the photograph's inherent mobility. As Edwards notes, "photographs have divergent, nonlinear, social biographies spread over divergent multiple material originals and multiple, dispersed, and atomized performances." 23 This understanding of cultural biography is central in my approach to writing about the photographs central to this thesis.

Edwards' seminal work on photographs also provides me with a theoretical model for addressing the non-visual aspects of photographs and their social and material work. ${ }^{24}$ A photograph is more than just an image. The photograph, in whatever form, is a tangible

\footnotetext{
${ }^{20}$ Igor Kopytoff, "The Cultural Biography of Things: Commoditization as process."

${ }^{21}$ Ibid, 68.

${ }^{22}$ Elizabeth Edwards, "Objects of Affect: Photography Beyond the Photographic Image," Review of Anthropology, 41 (2012), 221-234.

${ }^{23}$ Edwards, "Objects of Affect: Photography Beyond the Photographic Image," 223.

${ }^{24}$ Ibid, 221-234.
} 
object with unique physical properties. A silver-gelatin print, for example, has a paper base and a delicate emulsion layer, which holds the image. There might also be writing on the reverse side of the photograph, or glue residue on the image layer from having been previously held within an album with photograph corners. These factors are important in understanding the materiality of photographs. This model also enables me to address the materiality of the photographs in the Harmon fonds into my analysis. ${ }^{25}$ The Harmon collection exists in multiple forms, including commercial photographic prints (historical and contemporary), archival photographs (cellulose-nitrate negatives, lantern slides, silver-gelatin postcards), reproductions in books, and digital scans. As Elizabeth Edwards states, "Photographs [are] profoundly social objects of agency that cannot be understood outside the social conditions of the material existence of their social functionthe work that they do. ${ }^{, 26}$ By analyzing Harmon's photographs of Indigenous peoples through the lens of Material Culture studies, I can move beyond the assumption that they are purely images that objectify racialized bodies. This does not mean that I think that such photographs were not stereotypical representations intended to objectify the sitters. But to better understand the social constructions and perpetuations of negative stereotypes, I believe we must examine the role of the material work and, therefore, the social context of photographs to open up a new interpretive space to comprehend representations of Indigenous subjects.

In addition to considerations of a photograph's materiality, this thesis is also attentive to the specific codes of the photographic image. For this, I look to the work of

\footnotetext{
25 Elizabeth Edwards and Janice Hart, "Mixed Box: The Cultural Biography of a Box of "Ethnographic" Photographs," 47-61, in Elizabeth Edwards and Janice Hart, eds. Photographs, Objects, Histories: On the Materiality of the Image (London: Routledge, 2004).

${ }^{26}$ Edwards, "Objects of Affect: Photography Beyond the Photographic Image,” 290.
} 
Visual Anthropologist Deborah Poole. In her article, “An Excess of Description: Ethnography, Race, and Visual Technologies," Poole introduces the notion of the "temporal contingencies" and "excessive detail" present in ethnographic photography which disrupt the attempted 'fixity' in the representations. ${ }^{27}$ For my purposes, I adopt Poole's considerations of contingencies in Harmon's photographs, which could otherwise easily fall prey to analyses that focus only on their production as stereotypical photographs or types. Just as anthropological photographs were created as 'empirical' data to support ideas of race and racial difference, commercial photographs functioned as similar documents of cultural voyeurism. Such images were made attractive to tourist audiences by situating their Indigenous subjects in a way that attempted to emphasize cultural difference and disregard individual identities, political and social contexts, etc. Despite careful framing and composition, Harmon's photographs are full of contingencies revealing realities beyond the fixed image. These aspects of photographs that are captured by the camera exceed the intentions of commercial photographers like Harmon who aimed to sell images of Indigenous people that fit within the conventions of contemporary popularized ethnographic representations. ${ }^{28}$ Poole's conceptualization of photography will aid in my reading of the visual aspects of the photographs, which include tropes of representation, material culture signifiers, and expressions of modernity.

Specificity is integral to my method of research. I have chosen one part the Harmon fonds as a case study for this cultural biography in order to situate the photographs of Indigenous peoples within their historical and social context. Influenced

${ }^{27}$ Deborah Poole, "An Excess of Description: Ethnography, Race, and Visual Technologies," Review of Anthropology, 34 (2005), 159-179.

${ }^{28}$ Ibid. 
by Ann Laura Stoler's article "Colonial Archives and the Arts of Governance," I engage with the Byron Harmon fonds as a "site of knowledge production" 29 and treat the collection or archive itself as a subject rather than only a source for my research.

In order to adequately address the presence of Indigenous peoples in these photographs, I apply Anishinaabe scholar Gerald Vizenor’s concept “survivance."30 Vizenor defines the term as "an active sense of presence, the continuance of native stories, not mere reaction, or a survivable name. Native survivance stories are renunciations of dominance, tragedy, and victimry. Survivance means the right of succession or reversion of an estate, and in that sense, the estate of native survivancy." ${ }^{31}$ I will argue that the historical photographs of Indigenous people taken by Harmon depict stories of survivance and that the material existence of these documents make the photographs objects of survivance.

To acknowledge my own subjectivity as a settler scholar writing about Indigenous communities, histories of colonization, and Settler-Indigenous interactions, I employ Leah Decter and Carla Taunton's suggestions from their article "Addressing the Settler Problem: Strategies of Settler Responsibility and Decolonization..,32 Their framework will aid in situating this study within my personal settler responsibility to decolonize and provide tools for working through what Decter and Taunton call a "critical settler lens." 33

${ }^{29}$ Ann Laura Stoler, "Colonial Archives and the Arts of Governance," Archival Science 2 (2002), 87.

${ }^{30}$ Gerald Vizenor, Manifest Manners: Narratives on Postindian Survivance (Lincoln and London: University of Nebraska Press, 1994).

31 Ibid, vii.

${ }^{32}$ Leah Decter and Carla Taunton, "Addressing the Settler Problem: Strategies of Settler Responsibility and Decolonization,” Fuse Magazine 36 (2013), 32-39.

${ }^{33}$ Decter and Taunton, "Addressing the Settler Problem: Strategies of Settler Responsibility and Decolonization," 4. 
My responsibility as a settler is to work on decolonizing the collections I work with and write about.

\section{Organization of the Thesis}

Chapter One will provide a brief biography of Byron Harmon in relation to his photographic work in the early twentieth century. He will also be situated within the history of photography in Banff, the Rocky Mountains, and the Western edge of the southern plains. I will discuss Harmon's work in the context of conventions of photographing Indigenous peoples for commercial or anthropological purposes. Further, this chapter will trace the provenance of the fonds from its origins to where and how I have become acquainted with it.

Chapter Two will provide background on the Indigenous community most photographed by Harmon. As such, it will discuss the political, social, economic, and geographical context in which the photographs were made. In order to do this I introduce Ĩyãhé Nakoda culture, the history and effects of Treaty 7, the creation of reserves, the pass system and how these events coincided with the creation of Banff National Park. I also examine Indigenous exclusion from Banff National Park and events in which their presence in the park was seen as a necessity by an image crafted by the tourist industry. Finally, to illustrate these themes, I will introduce the key local event that spectacularized and commodified the Indigenous image: the Banff Indian Days.

Chapter Three comprises close analyses of a selection of Harmon's photographs depicting Indigenous subjects. Through detailed attention to the material, visual, and contextual properties of these photographs, I bring them into a contemporary 
conversation to re-imagine their cultural or social biography. I treat the photographs as documents of difficult histories that can be re-contextualized though a multivalent analysis. 


\section{Chapter One}

\section{Photographic Contexts and Byron Harmon}

In January of 2016 I returned to Banff for a week to continue the research on the Harmon fonds at the Whyte Museum of the Canadian Rockies that I had begun the previous summer. I was performing the painstaking task of looking at every scan of every Harmon negative in the archives collection, having decided that if I was to write about a selection of the images, I should look at them all. I saw countless snow-capped mountain peaks, stoic glaciers, still and clear mountain lakes, pack trains and climbers in the backcountry, skiers, many views of Banff Avenue and the Harmon Building, Canadian Pacific trains, avalanche snow sheds, hotels, town events, the building of the Banff bridge, Indigenous peoples, and family portraits. Near the end of my survey, I came upon a group of panoramic photographs. One in particular caught my attention: an image described in the museum records as "Teepees on the Banff Springs Golf Course site, Banff, ca.1910."34 (Fig. 1.1) I took a careful look at the negative, impressed by the size of the cellulose-nitrate negative-long and narrow_- holding an image that captures an expansive scene running across the horizon line. The negative shows its age with some silvering of the emulsion, slight warping, and scratches that are seen when the lights of the archives workroom shine on the surface.

The photograph depicts an open, flat mountain valley where a long row of tipis stretch across the grassy ground. Behind them stands a grove of trees, perhaps lining the bed of the Bow River. Rising above the tipis, trees and valley floor, are smooth, tree

\footnotetext{
${ }^{34}$ Byron Harmon, "Untitled: [teepees]" [1910], Described as "Site of Banff Springs Hotel golf course," V263/NA-6379, Byron Harmon Fonds, Archives \& Library, Whyte Museum of the Canadian Rockies.
} 
covered mountains and one towering mountain with an impressive jagged peak. On the far left side of the photograph, a group of men gather near a wagon. A flagpole has been erected in the wagon whose flag rests folded upon its self. Among the tipis can be seen people, wagons, horse tackle, and other items difficult to make out. The tipis and the trees occupy the centre ground of the image, tracing the horizon line. Grass fills an expansive foreground. I find the horizontal emphasis of the photograph striking. When imagining mountain photography, I think about the privileging of the vertical that is both desired and necessitated by the very landscape being photographed.

The photograph is likely the encampment set up to accommodate the Indigenous participants for the duration of Banff Indian Days, ${ }^{35}$ I open this chapter with it because for me it crystallizes key aspects about the Harmon fonds and the nature of his photographs of Indigenous peoples. This image is striking not only visually but also conceptually. Since Harmon was primarily a landscape photographer, I imagine this photograph as a bridge between those images and his images of Indigenous people. His keen use of compositional elements and panoramic framing communicate the expansiveness of Rocky mountain landscape while foregrounding the tipis within this environment. Instead of making an image of a mountain peak or range that highlights their monumentality or a closely cropped photograph of an Ĩyãhé Nakoda person, here Harmon has found a visual meeting ground of picturesque landscape and Indigenous presence in the Bow Valley.

${ }^{35}$ This is significant because the Banff Indian Days camp was later moved to a space north of the town site, in front of Cascade Mountain. 
In this chapter, I explore the provenance and history of the Byron Harmon fonds. I also provide a brief overview of the historical context of photography in Western Canada, which includes commercial, amateur, and government photographers. I demonstrate that societal and historical factors influencing the development of photography in the Canadian West and the practice of making images of Indigenous peoples is integral to the cultural biography of the Harmon photographs of Indigenous peoples.

Byron Harmon was born near Tacoma, Washington in 1876 and began his professional photographic career in the mid-1890s with his opening of a portrait studio there. Soon after establishing that business venture, Harmon left Washington State to travel as an itinerant photographer. He first journeyed east across the United States and then continued westward in Canada from the east coast to the Rocky Mountains. ${ }^{36}$ Harmon settled in Banff in 1904, opening the town's first commercial photography studio on its main street, Banff Avenue. He soon began to shoot extensively in the mountains and expanded his business operations to cater predominantly to tourists. Harmon sold individual photographs, postcards and photographic view books to tourists out of his studio while also selling photographs to international publishers, the Canadian Government, and the Canadian Pacific Railway.

Once the Canadian Pacific Railway (CPR) track from Calgary to Banff was completed in 1883 , followed shortly by the completion of the transcontinental railroad in 1885, the Rocky Mountains became a more accessible subject for itinerant photographers and their numbers swelled. Notable amongst this early group are Underwood and

\footnotetext{
${ }^{36}$ Bart Robinson, "A Biographical Portrait of Byron Harmon," in Great days in the Rockies: The Photographs of Byron Harmon, 1906-1934, eds. Carole Harmon and the Peter and Catharine Whyte foundation (Toronto: Oxford University Press, 1978), 7-10.
} 
Underwood Publishers, Boorne and May, A.B. Thom, and Dan McCowan. ${ }^{37}$ During this same period, to promote the newly opened railroad and to further its efforts at creating a tourist industry in the Canadian Rockies, the CPR hired professional photographers William Notman and Co. of Montreal, Alexander Henderson, and Oliver B. Buell, among others to make images of the Rocky Mountains along the railway line for advertising purposes. ${ }^{38}$ By the turn-of-the-century, photographers had begun to take up residence within the town of Banff itself. Contemporary to Harmon, commercial photographers in Banff included Elliot Barnes, George Noble, and, briefly, G. \& W. Fear. ${ }^{39}$ Banff was also home to many amateur photographers and avid collectors of the medium. Some of the more notable collectors such as Mary Schäffer, Norman Luxton, and Pearl and Philip Moore acquired significant holdings of Harmon images. ${ }^{40}$

An interior view of the Harmon store on Banff Avenue shows one side of the store and how extensive the marketing of the photographs was to tourist consumers. (Fig. $1.2)^{41}$ I am struck by the sheer number of photographic products on display. Hanging from the roof in rows extending to the back of the space are framed prints, some of which I can recall seeing myself, still hanging in what is now known as the Harmony Lane

\footnotetext{
${ }^{37}$ A resident of Calgary, Alberta.

${ }^{38}$ E.J. Hart, The Selling of Canada: The CPR and the Beginnings of Canada (Banff: Altitude Publishing, 1983), 32-33.

${ }^{39}$ The source for the names of these photographers is the fonds levels descriptions at the Archives and Library, Whyte Museum of the Canadian Rockies Archives. Elliot Barnes Fonds, V48; Noble Family Fonds V360; Mary Schäffer Fonds M79/V527

${ }^{40}$ As a part of my archival research, I sought out Harmon photographs in other collections to better understand how and by whom his images were collected and circulated. Harmon made some of his negatives into lanternslides, which were subsequently used in lectures by Schäffer and Moore. Both had moved to Banff from the eastern United States (Schäffer from Pennsylvania and Moore from New Jersey) and became prominent community members. They were both known to travel in the United States and, while on these trips, lectured about the Rocky Mountains and the people, places, and events there, including Indigenous peoples.

${ }^{41}$ Byron Harmon, "Harmon Store," [between 1903 and 1942], V263/NA-4221, Byron Harmon Fonds, Archives \& Library, Whyte Museum of the Canadian Rockies.
} 
Building. ${ }^{42}$ Lining all available wall space are framed photographs. On the right side of the room, one after another, wooden stands hold postcards and small prints. On one display table, Harmon's self-published photolithographic books can be seen. The left side of the image space is occupied by a jewelry counter that has framed prints leaned against its right side. In front of that case, a display has been built around a pillar holding yet more rows of prints. This photographic document as a whole speaks to how prolific and extensive Harmon's commercial enterprise was and may indicate how many of these very prints still circulate today.

Today, a large portion of the Byron Harmon collection of photographs is housed in the Archives and Library of the Whyte Museum of the Canadian Rockies. The fonds is comprised of approximately 10,500 photographic negatives, prints, postcards, transparencies, lanternslides and motion pictures with approximately 1,200 of the negatives exclusively depicting Indigenous subjects. A smaller portion of the collection remains with the Harmon family. Prints and other products were sold in the Harmon Gallery, which remained housed in the Harmon Building on Banff Avenue until 2013, and afterward online. Today, the family produces contemporary prints made from scans of the photographer's original negatives and prints. The contemporary prints are sold as editions or portfolios online. Some of Harmon's Indigenous portraits are marketed under the title "Stoney First Nations Portraits." 43

The Byron Harmon fonds, as it is now called in the Whyte Museum archives, was donated in 1975 by the photographer's family. The donation of the collection was

\footnotetext{
${ }^{42}$ Harmony Lane is the name of the historically restored building still owned by the Harmon family.

43 "Stoney Limited Edition Portfolio," http://www.byronharmonphotos.com/editions/stoneyLTD/index.html. Last Modified 2013.
} 
principally overseen by his granddaughter, Carole Harmon. For reasons of preservation, Harmon made copy negatives of the original cellulose-nitrate negatives, as many of them were in state of significant deterioration, ${ }^{44}$ this action was imperative because nitrate negatives are extremely fragile and potentially flammable. ${ }^{45}$ The copy negatives were produced using direct duplicate film to ensure proper recording of shadow and highlight details. Carole Harmon also made a series of contact prints that are now used in the reference binders at the Whyte Museum archives. The production of copy negatives was funded through the Peter Whyte Foundation, a grant from the Canada Council for the Arts, the Riveridge foundation, and Byron Harmon Photos (the company name at the time, owned by Don Harmon). ${ }^{46}$ This process of copying and organizing the collection's negatives was necessary not only for preservation but also for public access. In Carole Harmon's final report to the Canada Council, she acknowledges editing down the initial holding of approximately 5000 cellulose-nitrate negatives. As she explained in that report, "considerations of historical, aesthetic and technical quality were weighed. Those negatives, which were historically or aesthetically superior, were retained even if technically poor. Those of least interest from the above criteria were eliminated. The total chosen for preservation was approximately $3700 .{ }^{, 47}$ With negatives that were exact duplicate images, she chose, when possible, to preserve the negatives from which Byron Harmon had printed. Despite this selection process, none of the he negatives were

\footnotetext{
${ }^{44}$ When the conservation process began, the Byron Harmon negatives were stored in wooden file cabinet in the Harmon's building, then the business run by Don Harmon (the son of Byron). Carole Harmon, interview with author, March 2016. Ethics clearance was granted for this interview through the Carleton University Research Ethics and Compliance Office. Project \#104064.

${ }^{45}$ María Fernanda Valverde Valdés, Photographic Negatives: Nature and Evolution of Processes (Rochester, NY: Advanced Residency Program in Photograph Conservation, 2005), https://www.imagepermanenceinstitute.org/webfm_send/302/

${ }^{46}$ Carole Harmon, interview with author, March 2016.

${ }^{47}$ Carole Harmon research files, M65, Archives \& Library, Whyte Museum of the Canadian Rockies.
} 
discarded and were donated in their entirety to the Whyte Museum with the rest of the collection; the unselected negatives do not have a respective copy negative but remain with the other original cellulose nitrate negatives. ${ }^{48}$

While a relatively small portion of his overall collection, Harmon's photographs of Indigenous peoples are nonetheless important resources. They aid in studying the practices of settler photographers making images of Indigenous peoples in Western Canada as well as the political and social dynamics of the time. Many of Harmon's photographs of Indigenous peoples were taken at the annual Banff Indian Days, between approximately 1906 and $1929 .^{49}$ Additionally, he shot numerous photographs at the Banff Winter Carnival; on the Ĩyãhé Nakoda reserve at Morley, Alberta; at Kootenay Flats near the Saskatchewan River crossing, close to Banff; and near Windermere, British Columbia. Many of the Indigenous people depicted in Harmon's photographs are of members of the Iyãhé Nakoda First Nation. The other known nations pictured in his collection include, but are not limited to, the Tsuu T'ina (Sarcee), Ktunaxa (Kootenay), and Siksika (Blackfoot), Secwepemc (Shushwap) First Nations.

Harmon's work is part of a long history of Settler photographers representing Indigenous peoples on the Canadian prairies and in the Rocky Mountains. Approximately forty years before Harmon's arrival in the Banff area, the first photographers travelled from eastern Canada to document the prairies. In 1858, for example, the governmentsponsored Assiniboine and Saskatchewan Exploring Expedition used photography extensively for the purpose of documenting the state of the landscape and those

\footnotetext{
${ }^{48}$ Carole Harmon, interview with author, March 2016.

${ }^{49}$ These dates are taken from the negative envelopes of the photographs in the archives, and any publication captions of the image. Unfortunately, there are not supporting textual documents, which could otherwise give a more precise date range.
} 
inhabiting the area ${ }^{50}$ Images from this expedition are believed to be the first government photographs of First Nations and Métis residing in the Plains area taken by Humphrey Lloyd Hime (1833-1903), the official photographer of the expedition. ${ }^{51}$ The images were made using delicate glass plate negatives and the wet plate collodian method, which necessitated a mobile dark room tent and an arduous photographic process. ${ }^{52}$ In addition, geological and boundary surveys were undertaken by the government in anticipation of Western settlement that relied on photographic records. The establishment of the $49^{\text {th }}$ Parallel boundary between Canada and the United States led to the formation of the British North America Boundary Commission from 1872 to 1874. George W. Dawson, the key photographer employed by this survey, also surveyed areas in Southern Alberta (near the Bow, Belly, and St. Mary Rivers). On both of these assignments, Dawson made many photographs of Indigenous subjects. During assignments in Alberta, for example, he is known to have photographed Siksika and Nēhiyawēwin communities. ${ }^{53}$

Photography arrived on the east side of the Rocky Mountains, likely around the early 1870 s, with the CPR survey of $1872 .{ }^{54}$ The photographer Charles Horetzky (18401900) was a member of this survey party, "which was examining the country between Red River and the Yellowhead Pass. He documented scenes from Fort Carleton to Vermillion, and over to Edmonton, Jasper, and Rocky Mountain House. ${ }^{, 55}$ He was a

${ }^{50}$ Andrea Kunard, "Relationships of Photography and Text in the Colonization of the Canadian West: The 1858 Assiniboine and Saskatchewan Exploring Expedition." International Journal of Canadian Studies 26 (2002): 77-100.

${ }^{51}$ Silversides, Face Pullers: Photographing Native Canadians 1871-1939, 2.

${ }^{52}$ Richard J. Huyda, Camera in the Interior: H.L. Hime, Photographer: The Assiniboine and Saskatchewan Exploring Expedition (Toronto: The Coach House Press, 1975).

${ }^{53}$ Silversides, Face Pullers: Photographing Native Canadians 1871-1939, 2.

${ }^{54}$ Ibid, 2.

${ }^{55}$ Ibid, 2. 
valuable part of the railway surveys and at times performed surveys on exploratory routes by himself. ${ }^{56}$

Resident photographers who settled in the newly formed communities of Western Canada in the late nineteenth century also depicted Indigenous peoples, for both personal and commercial purposes. In coastal communities of British Columbia, it was common for Indigenous families and individuals to visit studios and engaged in the colonial society and economy through sitting for portraits. ${ }^{57}$ This was not as usual an occurrence on the prairies or in the Rockies as the economic and colonial history of the region differs from British Columbia. Much of the studio portraiture made on the eastern side of the Rockies was intended for commercial sale and not personal memento. ${ }^{58}$ Because of the creation of reserves and the enforcement of the "pass system," 59 access to studios and the means to pay for a portrait were limited on the eastern side of the Rockies. This lack of economic and physical mobility, when compared to that of Indigenous communities of the Northwest Coast, created a unique local power relationship between settler photographer and Indigenous sitter. In Face Pullers: Photographing Native Canadians 1871-1939, Brock Silversides outlines the impetus for Western Canadian resident photographers to make images of Indigenous peoples as being one of monetary gain.

${ }^{56}$ A.J. Birrell, Into the Silent Land: Survey Photography in the Canadian West, 184801900 A Public Archives of Canada Travelling Exhibition (Ottawa: Information Canada, 1975), 29-30.

${ }^{57}$ Carol Williams, In Framing the West: Race, Gender, and the Photographic Frontier in the Pacific Northwest (New York: Oxford University Press, 2003).

${ }^{58}$ While I have yet to find definitive proof of this, nor do I intend to speak for all photographs taken at this time, I argue that the Indian act of 1876 (reserve system and the pass system) affected the mobility (economically and physically) in Indigenous communities. They were therefore mostly photographed during events like the Calgary Stampede, Banff Indian Days, and events hosted for visiting politicians or royalty when they were permitted to leave the reserves for the benefit of the settler communities or government. Private, commissioned portraits like those made on the Northwest coast, to me, are rare.

${ }^{59}$ This legislation is discussed in Chapter 2: Indigenous Contexts and the Ĩyãhé Nakoda First Nation. 
"One must always keep in mind that the chief incentive for taking photographs of Native people was money. The availability of Indian scenes in photographers' advertisements usually guaranteed a steady flow of curiosity, if not business. ${ }^{, 60}$ If I were to apply this argument to the tourist-based economy in Banff, would it illuminate Harmon's photographs of Indigenous peoples?

Any account of photography of North American Indigenous populations would be incomplete without mention of Edward S. Curtis (1868-1952) and his influential twentyvolume publication The North American Indian. ${ }^{61}$ Curtis, along with many other ethnographic photographers, reflected the precepts of salvage ethnography in their work. For Curtis, like many contemporaries, the Indigenous peoples of North America were a 'vanishing race' whose disappearance he believed was imminent. He felt it was his duty to document these 'disappearing' peoples and their ways of life through the photographic image. In A Cannibal in the Archive: Performance, Materiality, and (In)Visibility in Unpublished Edward Curtis Photographs of the Kwakwaka'wakw Hamat'sa, Aaron Glass explores the complex nature of Indigenous agency in Edward Curtis' photographs as well as the position of Curtis as both an ethnographic and commercial photographer. Of the lasting impact Curtis had on popular notions of what and who Indigenous North Americans are, Glass states, "indeed, the endless reproduction of certain Curtis imagesin his own day, but especially since the so-called Curtis revival of the 1960s and 1970sin myriad coffee table books, posters, calendars, and screen savers, has contributed to the creation of fully frozen, decontextualized, and iconic fragments of Native American

\footnotetext{
${ }^{60}$ Silversides, Face Pullers: Photographing Native Canadians 1871-1939, 3.

${ }^{61}$ The twenty-volume work is available online through Northwestern University: http://curtis.library.northwestern.edu/curtis/toc.cgi
} 
identity, history, and visual culture." ${ }^{62}$ Unfortunately, it is through the continuous reproduction and distribution of Curtis' work (often without his extensive textual records), that many have gleaned their knowledge or visual imagination of Indigenous peoples. According to Glass, Curtis was technically a commercial photographer under the guise of an ethnographer. His photographs were published as commercial products and America's most influential people backed his ventures or 'field work'. Again, according to Glass, Curtis' work was "constrained in part by perspectives of his powerful patrons, including Theodore Roosevelt, J.P. Morgan, and Frederick Hodge, ${ }^{, 63}$ a group of men who would have been interested in a particular image of Indigenous peoples. Despite all of this, in Glass' view, "the previously passive an presumable 'vanished' Indian reemerges as an active player on the photographic frontier of colonial modernity." ${ }^{64}$ In this way, imagining the Indigenous subjects in Curtis' or Harmon's photographs as vital players in the process of photography is important to reimagining the legacy of such images.

Unlike Curtis, Harmon was strictly a commercial photographer and had no known interest in ethnographic pursuits; indeed, his practice may be closer to settler photographer H.H. Bennett of Wisconsin (1843-1908). Bennett is well known today for his portraits of Ho-Chunk peoples. ${ }^{65}$ Both Bennett and Harmon had studios in tourist towns; both were not solely concerned with Indigenous portraits; and they both

${ }^{62}$ Aaron Glass, "A Cannibal in the Archive: Performance, Materiality, and (In)Visibility in Unpublished Edward Curtis Photographs of the Kwakwaka'wakw Hamat'sa," Visual Anthropology Review, 25 (2009): 130.

${ }^{63}$ Ibid, 130.

${ }^{64}$ Ibid, 131.

${ }^{65}$ Amy Lonetree has also written extensively about photographic representations of Ho-Chunk peoples by photographer Charles VanSchaick in Amy Lonetree, "Visual Native Survivance: Encounters with My Ho-Chunk Ancestors in the Family Photographs of Charles Van Schaick." In People of the Big Voice: Photographs of Ho-Chunk Families by Charles Van Schaick, 1879-1942. Edited by Tom Jones, Michael Schmudlach, Matthew Daniel Mason, Amy Lonetree, \& George A. Greendeer, Madison (Wisconsin: Wisconsin Historical Society Press, 2011), 13-22 
photographed Indigenous peoples in a tourist-based economic context. This context is important to understand the conditions under which the photographs were taken as well as the photographer-sitter relationship. In Hoelscher's examination of this interaction between Bennett and the Ho-Chunk, he states, "The resulting photographic, social, and economic encounters between the Dell's earliest promoter of tourism and its indigenous people were highly complex and suggestive of the contradictions inherent in postcolonial relationships more generally." 66 The contradictions present in photographs are significant to the reading of Harmon's photographs because each image speaks to this complex relationship. Hoelscher goes on to say, "each of these actions - and the stories undoubtedly told about them - suggests presence, self-reflexivity, and agency. A camera may have been a tool of domination, but it could also be turned into a technology of survivance." ${ }^{67}$ To me, the photographic objects and visual statements resulting from using this technology are integral for tracing histories of Indigenous presence in spaces and histories from which they are otherwise erased. The photographs therefore become what I consider - objects of 'survivance.'

The moment of taking the photograph, however, is a complex interaction. In discussing Bennett, Hoelscher calls the interaction between photographer and sitter "transcultural encounters" which are according to him "characterized as profit driven exchanges between photographer and the people he considered photographic subjects" ${ }^{\text {"68 }} \mathrm{I}$ believe that this is precisely the type of photographic 'encounter' that took place between Harmon and the Indigenous subjects he portrayed. While it is unknown whether Harmon

${ }^{66}$ Steven D. Hoelscher, Picturing Indians: Photographic Encounters and Tourist Fantasies in H.H. Bennett's Wisconsin Dells (Madison, Wisconsin: University of Wisconsin Press, 2008), 136.

${ }^{67}$ Hoelscher, Picturing Indians: Photographic Encounters and Tourist Fantasies in H.H. Bennett's Wisconsin Dells, 136.

${ }^{68}$ Ibid, 101. 
paid his sitters, he was still photographing them with the intention of selling the resulting photographs as commodified objects. ${ }^{69}$ Harmon's photographs of Indigenous subjects were taken and sold during a time when tourism burgeoned in the Canadian Rockies. But, simultaneously, Indigenous peoples of the area were experiencing the increased effects of settler-colonialism. ${ }^{70}$ Hoelscher considers this historical context important to the understanding photographs produced at this time. "The rise of commercial photography, the emergence of mass tourism, and the final colonization of Native Americans all occurred simultaneously in the latter half of the nineteenth century, producing a historical intersection that is far from coincidental." ${ }^{, 11}$ I suggest that this point of intersection is integral to an understanding Harmon's photographs of the Ĩyãhé Nakoda and other Indigenous peoples. While Harmon was making his images at Indian Days and other events, the Indigenous subjects of his photographs were experiencing dire effects of colonial control and genocide. To me, the photographs are important documents of Indigenous presence in the spaces — physically and ideologically - that were being aggressively colonized or from which they were excluded.

Harmon's photographs cannot be separated from the context in which they were created. Reading the images in the early twenty-first century demands that we are cognizant of their origins as commercial photographs taken during a time of mass tourism and settler-colonial oppression in the Rockies. From the time they were created to Carole Harmon's preservation efforts and from the first archivist cataloguing the negatives to me

\footnotetext{
${ }^{69}$ In my interview with Carole Harmon, she was asked if she knew if Harmon had paid his Indigenous sitters for their likeness, and stated that she did not know. Carole Harmon, interview with author, March 2016. Nation.

${ }^{70}$ I speak to this history in depth in Chapter 2: Indigenous Contexts and the Ĩyãhé Nakoda First

${ }^{71}$ Hoelscher, Picturing Indians: Photographic Encounters and Tourist Fantasies in H.H. Bennett's Wisconsin Dells, 9.
} 
looking through them in 2016, the provenance of the photographs has a great deal of influence on how they are interacted with today. Now the responsibility for how they are seen and understood rests not with the photographer but with a larger network of archivists, curators, publishers and viewers. This chapter has provided a brief introduction to Harmon's work within the historical context of Western Canadian photography as well as to the complex journey of the photographs I researched in the archives. This, however, is only part of the cultural biography of these objects; it is integral to this thesis to also consider the social and political context of those photographed. 


\section{Chapter Two}

\section{Indigenous Contexts and the Ĩyãhé Nakoda First Nation}

There is a series of photographs in the Byron Harmon fonds at the Whyte Museum of the Canadian Rockies that are unlike the others in the collection. These eighteen images feature Indigenous subjects seated in front of a cloth backdrop. I must have spent hours in the archives looking closely at this group of photographs. Of all of the photographs taken by Harmon outside of the studio, these seem to me to be the closest to family or formal portraits. ${ }^{72}$

One of these photographs is identified as an image of "Lucy Ear." (Fig. 2.1) Lucy Ear poses with two small children. She sits in the centre wearing a diamondpatterned dress and knitted sweater made of dark wool with white stripes adorning the chest and arms. One of the buttons of her sweater is visible; light coloured and spherical, it shines in the sunlight. Ear looks into the camera, her eyes squinting in the sun. Her braided hair is tucked under the collar of her sweater, while wisps of hair on the top her head blow in a breeze or gust of wind. On her left side, a young girl wearing a knitted skirt and sweater leans into Ear's arm. A striped cotton shirt appears, bunched up around the girl's collar. The girl's hair has also been braided in two plaits. One braid rests on her left shoulder, but the very tip is blurred from movement during the exposure. Her eyes look toward the camera, with her brow furrowed and mouth as she speaks or possibly

\footnotetext{
72 There are, however, some that have the subject in a profile view seated in front of a backdrop that resemble compositional tropes of ethnographic photographs.

${ }^{73}$ Byron Harmon, "Lucy Ear," [ca.1920-1930], V263/NA-3218, Byron Harmon Fonds, Archives \& Library, Whyte Museum of the Canadian Rockies; the negative envelope reads: "Lucy Ear, V263/NA71-3218." It is a 4x5, cellulose nitrate negative. Written in ink directly on to the emulsion side of the negative is "LUCY EAR". I studied both a scan and the negative. The writing on the side of the negative might be Carole Harmon's, Byron Harmon's, or that of an assistant employed by Harmon. Carole Harmon, interview with author, March 2016.
} 
yawns; the girl's expressive movement is frozen in the split second exposure. On Ear's lap sits another child, a small boy. He is dressed in knee socks, light coloured shorts, and a linen or cotton shirt with a collar buttoned up to the neck. A small white hat sits snugly on his head and the fine hairs that peak out from underneath it are swept up by the wind. The toddler's eyebrows wrinkle as he looks outside the frame, away from the camera, perhaps distracted by something I cannot see. Lucy has her right hand firmly clasped around his waist and her left hand clutches his arm, angled in a way to suggest that she is attempting to hold the squirming child still for the picture. The sun appears to be shining directly on this scene; I can see sharp, dark shadows cast on their faces and clothing. Behind them hangs a backdrop that appears to be made of a light coloured, possibly white, canvas. It is slightly out of focus due to the limited depth of field. Possibly fastened between trees, the sheet is pulled taut and looks to be blown by the wind at the moment of exposure. A large crease in the fabric casts a dark shadow across the top left corner, while smaller wrinkles and stretch marks cast tiny shapes all over. Sprawling across the top and right side of the fabric are shadows cast by tree branches. While the backdrop obscures the landscape beyond, the shadows cast on the blanket are an index of the nature that surrounds them, representing a sort of context that the photographer attempted to obscure.

This photograph has the appearance of a casual family picture, with the shutter released prematurely while the sitters are in the middle of preparing their pose. The mother is attempting to wrangle the fidgeting infant on her lap and appease his older sibling, who stands skeptical of this whole enterprise. If this is a sort of family portrait, 
who are they? What was happening in their community? What was happening in their lives beyond the photograph?

I believe that these questions are important to the reading of the Harmon photographs and to understanding the Indigenous subjects in his images: their experiences of modernity, their presence in spaces they were excluded from by law, their kinship and friendship ties, and their resistance to colonial oppression, among other concerns. These considerations are integral to the writing of a cultural biography of the Harmon photographs.

In this chapter I will address the effects of the creation of Banff National Park had on Indigenous peoples, which are integral to understanding the significance of photographs of the Ĩyãћé Nakoda, specifically, as documents of their presence in the park and the town site. To further understand the significance of these photographs, I will provide a brief history of the Ĩyãhé Nakoda and Treaty 7. The presence of Indigenous bodies in Harmon's photographs, in the national park, and later in the archives all contribute to a continuum of Indigenous presence and agency. In order to analyze Harmon's photographs I must first outline the social and cultural contexts of their making.

Byron Harmon's photographs were taken during a time of great change and upheaval for the Indigenous peoples he depicted, particularly the Ĩyãhé Nakoda. As noted earlier, the Ĩyãhé Nakoda are perhaps most commonly known and referred to by settlers as the Stoney or Stoney Nakoda. İyãhé Nakoda is the self-determined name of the First Nation. ${ }^{74}$ For this reason I use this term instead of other English or settler iterations.

74 “'Origin,” http://www.rockymountainnakoda.com/, last modified 2015. 
Their marginalization and subjugation by the Dominion government dictated social and political dynamics between settler and Indigenous populations in the Banff and Bow River area. As with other First Nations of Western Canada, the signing and implementing of the Numbered Treaties and the Indian Act greatly impacted the Iyyãhé Nakoda culture.

Euro-Canadian settler exploration and land surveys in the west had changed aspects of Indigenous cultures across the plains and into the Canadian mountain regions; however, the signing of treaties and the completion of the CPR caused irreparable changes. As mentioned above, two pieces of legislation affected the Ĩyãћé Nakoda significantly: the signing of Treaty 7 and the Indian Act of 1876 . The combination of the two legal documents negatively affected the First Nations signatories-including the İyãhé Nakoda—while benefiting the Dominion government. Signed in 1877, the treaty was also negotiated with the Tsuu T'ina (Sarcee), Kainai (Blood), Siksika (Blackfoot), and Piikani (Peigan) First Nations at Blackfoot Crossing.

After the Dominion government's acquisition of Rupert's Land from the Hudson's Bay Company under the HBC charter, the government asserted power over the newly acquired area known as the Northwest Territories. Between 1871 and 1921, eleven treaties were signed between the Dominion government and numerous Indigenous peoples; cumulatively, they are known as the 'Numbered Treaties.' According to Indigenous and Northern Affairs Canada (INAC), "these treaties covered the area between the Lake of the Woods to the Rocky Mountains to the Beaufort Sea." ${ }^{75}$ To the government, the negotiation and signing of these treaties were part of a set of strategic

\footnotetext{
75 Indigenous and Northern Affairs Canada, The Numbered Treaties (1871-1920). Indigenous Affairs and Northern Affairs Canada http://www.aadncaandc.gc.ca/eng/1360948213124/1360948312708
} 
acts to move forward on their plans to settle and exploit the resources of the western and northern portions of the then newly created Dominion of Canada.

According to James Daschuk in Clearing the Plains: Disease, Politics of Starvation, and Loss of Aboriginal Life, "The numbered treaties between the Frist Nations and the west and the crown, negotiated between 1871 and 1877, attempted to reconcile the clash between two mutually exclusive economic systems in that fateful decade." ${ }^{, 76}$ Here, Daschuk is referring to Treaties 1 through 7. To First Nations groups, the treaties were signed in an effort to "secure their well-being in the face of an unsure future." ${ }^{77}$ They were understood as peace treaties between the nations to bring about stability and to halt the whiskey trade from the United States. To the government, these treaties were meant to facilitate the surrender of land by Indigenous Nations; facilitating peace was thought to aid in the safe settlement of non-Indigenous farmers and not for the benefit of the First Nations. ${ }^{78}$ In signing these documents, the government meant to ensure the legal right to the land and advance the aggressive settlement of the Canadian west.

Treaty 7 forced the Ĩyãhé Nakoda to live on reserve lands and subjected them to governmental assimilationist policies. These included the creation of the reserve at Morleyville (Morley), and an emphasis placed on creating an agriculturally based community on the reserve. Since the Ĩyãhé Nakoda had thrived in the area for generations

\footnotetext{
${ }^{76}$ James Daschuk, Clearing the Plains: Disease, Politics of Starvation, and Loss of Aboriginal Life (Regina, Saskatchewan: University of Regina Press, 2013), 79.

${ }_{77}$ Daschuk, Clearing the Plains: Disease, Politics of Starvation, and Loss of Aboriginal Life, 79.

${ }^{78}$ Hildebrant et al., The True Spirit and Original Intent of Treaty 7 (Montreal: McGill-Queen's University Press, 1996), 113.
} 
through subsistence hunting and gathering, they were resistant to settling in one location allotted by the government. $^{79}$

Treaty negotiations were and remain today highly contentious. Because treaty documents were typically drafted before meetings were established and were disseminated to Indigenous signatories in poorly translated form, the balance of power rested with the government. In The True Spirit and Original Intent of Treaty 7, elders from Treaty 7 signatory groups reflect on the treaty-signing process and explain the continuing effects of the legislation. In these oral history interviews, elders state that even if the interpreters were proficient enough in both Indigenous languages and English, many of them could not translate or perhaps understand the legal jargon of the treaty document. The interpreter provided or volunteered for the Ĩyãhé Nakoda was Reverend John McDougall. ${ }^{80}$ As Nakoda Elder Bill Mclean explains,

The White people brought their pre-written treaty document fully understanding the terms in it...interpreters were not proficient to fully comprehend legal wordings. But on the other hand, the government people were well versed in the legal jargon. For us Stoneys, we didn't have an interpreter. Only John McDougal was there for the Stoneys. They say he only knew a limited vocabulary of Cree, not very well versed in that language. So all he did, they say, was to try and relate only some part of the treaty terms in Cree to the Stoneys. That was all he could do. He did not give a full explanation of the implications of the legal wordings because he could not. ${ }^{81}$

The following excerpt from the Treaty exemplifies the complexity of the document:

Also whereas the Indians inhabiting the said territory have been informed by Her Majesty's Commissioners that is the desire of her majesty to open up for settlement, and such other purposes as to Her Majesty may seem meet, a tract of country, bounded and described as in hereafter mentioned, and to obtain the consent thereto of her Indian subjects inhabiting the said tract, an to make a treaty, and to arrange with them and Her Majesty, and between them and her Majesty's

\footnotetext{
${ }^{79}$ Ibid, 105.

80 Reverend John McDougall was a Methodist missionary and pioneer.

${ }^{81}$ Ibid, 105.
} 
other subjects; and that her Indian people may know and feel assured of what allowance they are to count upon and receive from Her Majesty's bounty and benevolence $[. .$.$] And Her Majesty the Queen hereby agrees to with her said$ Indians, that they shall have right to pursue their vocations of hunting throughout the tract surrendered as heretofore described, subject to such regulations as may, from time to time, be made by the Government of the country, acting under the authority of her Majesty; and saving and excepting such tracts as may be required or taken up from time to time for settlement, mining, trading or other purposes by her Government of Canada, or by any of Her Majesty's subjects duly authorized therefore by the said Government. ${ }^{82}$

The legal rhetoric of Treaty 7, like all of the Numbered Treaties, is at best difficult to understand; with an inadequate translator, I would argue, it is incomprehensible. Worse, McDougall may not have been impartial in the process. Surveying land for the treaty settlement had taken place on separate occasions with different Ĩyãћé Nakoda bands. The survey group made up of elders chose multiple different locations to accommodate the wishes of bands that wished to continue to live on traditional territories. But while helping with the survey, McDougall only wrote down his own suggestions: that the reserve should be located at Morleyville, within the vicinity of his own Methodist mission. Ĩyãhé Nakoda would, therefore, have to stay in close proximity to and under the influence of the mission. This location did not benefit the Ĩyãhé Nakoda; they were not accustomed to living in this area year round. As Elder Lazarus stated, "traditionally Stoneys used the Morleyville area primarily as a wintering site and not a place of year round residence. $" 83$

The reserve land allotted to the Ĩyãhé Nakoda was poor farm land and the Indian agent as well as the local mission leaders discouraged seasonal migration patterns

\footnotetext{
${ }^{82}$ Ibid, 232.

${ }^{83} \mathrm{Ibid}, 105$.
} 
necessary for hunting and social or intertribal relationships. ${ }^{84}$ In 1885 , the year the CPR was completed, the pass system was introduced on reserves. Indian agents "who lived in the communities, both to provide surveillance and to serve the peoples' needs, were instructed by the Indian Affairs Branch to introduce the pass system in an attempt to restrict the movements of local peoples." ${ }^{, 85}$ Those who disobeyed the regulations and were found off reserve without documentation were punished with fines or imprisonment. ${ }^{86}$ Before the treaty signing, the Nakoda travelled great distances within and throughout the area, including the territory that would become Banff National Park, for hunting, migration and ceremonial purposes. ${ }^{87}$ The area was also an important to the Ĩyãhé Nakoda for gathering food plants, which are a steady source of calories and medicine plants that were significant to everyday life. ${ }^{88}$

In “'Let the Line Be Drawn Now': Wilderness, Conservation, and the Exclusion of Aboriginal People from Banff National Park in Canada," Theodore Binnema and Melanie Niemi speak to the purposeful exclusion of Indigenous peoples from Rocky Mountain Park (RMP - later Banff National Park). They state that in the early years of the RMP, Indigenous people were banned from most national parks in Canada and the United States. However, this exclusion was contrary to the lawful presence of permanent residents within the parks, including the park at Banff. "(T)hey were barred from Banff National Park (and other national parks) at a time when administrators assumed that it

\footnotetext{
${ }^{84}$ Mason, Spirits of the Rockies: Reasserting an Indigenous Presence in Banff National Park (Toronto: University of Toronto Press, 2014), 31.

${ }_{85}^{85}$ Mason, Spirits of the Rockies: Reasserting an Indigenous Presence in Banff National Park, 35.

${ }^{86}$ Ibid, 35.

${ }^{87}$ John Snow, These Mountains Are Our Sacred Places: The Story of the Stoney People (Calgary: Fifth House, 2005), 9.

${ }^{88}$ M. K. Lux, Medicine That Walks: Disease, Medicine, and Canadian Plains Native People, 1880-1940 (Toronto: University of Toronto Press, 2001). Decisions on where and when to move were often taken into consideration based on the growth cycles of certain food or medicine plants.
} 
was acceptable for national parks to have permanent residents." ${ }^{89}$ They go on to explain that even national parks founded before 1930 that did not have towns established within their boundaries, created town sites for the benefit of park visitors after the parks boundaries were established. What this proves is that exclusion of Indigenous people from the parks was not contingent upon the banning of any human presence in the park, or even the banning of human residence within the parks. The legislated prohibition of Indigenous people from the spaces where they had hunted, celebrated, gathered, and lived for centuries exemplifies systemic racist policies.

While most legislation regarding Indigenous peoples was initiated in the highest levels of the government, policies pertaining to Indigenous exclusion from the RMP had grassroots origins. Some of the loudest voices against Indigenous people, specifically the Ĩyãhé Nakoda people, hunting in the park and near its boundaries were European and settler sport hunters. They claimed that the Indigenous hunting practices were counter to their values. As Binnema and Niemi state, "For example, aboriginal people hunted for subsistence when sportsmen prided themselves on hunting for sport and for trophies, rather than for food." 90 The sportsmen went so far as to declare, "no one, not even aboriginal people had the right to hunt for subsistence." 91 This sentiment disregarded the reality of Indigenous communities and their need for hunting in the park. They relied upon the meat from the animals and the money from the sale of the products of their hunt to settlers (meat) and tourists (trophies).

\footnotetext{
${ }^{89}$ Theodore (Ted) Binnema and Melanie Niemi, “'Let the Line Be Drawn Now': Wilderness, Conservation, and the Exclusion of Aboriginal People from Banff National Park in Canada," Environmental History 11 (Oxford University Press: 2006), 725.

${ }^{90}$ Binnema and Niemi, "'Let the Line Be Drawn Now:' Wilderness, Conservation, and the Exclusion of Aboriginal People from Banff National Park in Canada," 730.

${ }^{91}$ Ibid, 731.
} 
The main reason put forth by the government, missionaries, and parks superintendents for the exclusion of Indigenous peoples from the park and for leaving the reserve land, was hunting. To missionaries and government officials focused on hardline assimilation and parks superintendents who had misguided ideas regarding the nature of how Indigenous hunting was occurring and changing at this time (including the sale of meat and trophies to Europeans in order to survive), it was imperative to bar the Ĩyãћé Nakoda from their hunting lands. Both positions maintained that it was 'un-civilized' for the Ĩyãhé Nakoda to be hunting and was counter to assimilation efforts for them to be off the reserve lands, away from the watchful control of the Indian agent and missionaries.

The pass system was also used to enforce the travelling ban, which legislated that Indigenous peoples should not travel beyond reserve boundaries. Park commissioners considered them intruders. Theodore Binnema and Melanie Niemi, for example, quote contemporary fisheries commissioner W.F. Whitcher, “... Those who now invade that territory are stragglers and deserters from their own reserves, where they are well cared for in food and clothing at the public expense." 92 As Dashuck has demonstrated, conditions for all Treaty 7 communities were in dire circumstances with the changes following the signing.

These exclusions made the invitation to the Ĩyãhé Nakoda (and later other Indigenous groups) to participate in Banff Indian Days notable. Binnema and Niemi state this change was led by the attractiveness of having "tamer Indians in the park." 93 Demeaningly, this coincided with measures to control the presence of predators in the

\footnotetext{
92 Ibid, 729.

${ }^{93}$ Ibid, 739
} 
park, a calculated effort to turn large game animals more docile and, therefore, attractive to park visitor. "The representation of 'Indianess' at Banff in the early twentieth century took on a new carnival-like form in the 'Banff Indian Days.' 'Indianness' could be reconstructed as a tourist friendly 'useful institution' in the park."

Banff Indian Days was an annual cultural festival hosted as a spectacle for tourists of the national park. Indigenous participants or performers travelled to Banff from various reserves and communities. The first Banff Indian Days was likely $1894^{94}$ when tourists were stranded at the Banff Springs hotel because flooding had washed out the train bridges. A local hunting guide, Tom Wilson, was charged with convincing a group of Nakoda to come to Banff to entertain the hotel's guests. This event was informally organized until 1902 when four Banff businessmen formed the Indian Days Committee. ${ }^{95}$ In "Naturalizing Race Relations: Conservation, Colonialism, and Spectacle at the Banff Indian Days," Jonathan Clapperton states, regarding the Indigenous participants,

Once in Banff, they would pitch a teepee 'Indian village,' decorate themselves in 'traditional' regalia, and provide a scene that according to boosters was how 'real Indians lived 100 years ago.' Activities varied yearly, but mainstays included parades, sporting competitions such as archery and races, and drumming, singing, and dancing. ${ }^{96}$

\footnotetext{
${ }^{94}$ Eleanor G. Luxton, Banff: Canada's First National Park, (Banff: Summerthought, 2008), 126. Banff Indian Days became an annual event by 1902.

95 Jonathan Clapperton, "Naturalizing Race Relations: Conservation, Colonialism, and Spectacle at the Banff Indian Days," The Canadian Historical Review, 94 (2013), 353-354.

${ }^{96}$ Clapperton, "Naturalizing Race Relations: Conservation, Colonialism, and Spectacle at the Banff Indian Days," 350.
} 
As mentioned above, Indigenous peoples on the plains and foothills of Alberta were under the control of the pass system, which forced them to stay on their respective reserves unless the Indian agent granted permission. ${ }^{97}$ As Mason states in The Construction of Banff as a 'Natural' Environment: Sporting Festivals, Tourism, and Representations of Aboriginal Peoples, "Although the presence of Aboriginal peoples was required during Indian Days and as a result they were recruited by tourism producers for their participation in the festival, a recent study demonstrates that during the period Aboriginal peoples were actively excluded from the national park and especially from the townsite itself." 98 Non-Indigenous government officials and businessmen in Banff, therefore, mediated activity in the park for Indigenous peoples.

According to Mason, "the Banff Indian Days were manipulated by tourism procedures to sell an image of the region using specific representations of aboriginal peoples while simultaneously forwarding capitalist economic objectives." 99 While opinions vary regarding both the commercial intentions of Indian Days and Indigenous sentiments about performing in the festival, the event was built on the premise that the Indigenous participants were viewed as existing in a pre-contact past.

A Harmon image titled “Indian Days at Banff Springs Hotel ca.1930?” (Fig. 2.2), shows an event or performance from Banff Indian Days on the grounds of the Banff Springs Hotel. ${ }^{100}$ Four men dressed in various forms of regalia are seated in the centre of

\footnotetext{
${ }^{97}$ Courtney Wade Mason, Spirits of the Rockies: Reasserting an Indigenous Presence in Banff National Park, 45.

${ }^{98}$ Courtney Mason, “The Construction of Banff as a 'Natural' Environment: Sporting Festivals, Tourism, and Representations of Aboriginal Peoples," 226.

${ }^{99}$ Ibid, 222.

${ }^{100}$ Byron Harmon, "Indian Days, at Banff Springs Hotel,” [ca.1930], V263/NA-3353. Byron Harmon Fonds, Archives \& Library, Whyte Museum of the Canadian Rockies.
} 
the tennis court. Four other men also dressed in regalia dance around the seated men while a larger circle or line of seated men, also in regalia, look on from the side. The line of seated figures extends beyond the image. Behind this crowd of dancers, drummers and singers, a tall fence rises and beyond it, a crowd of tourists looks on. Behind the crowd are tipis, the tops of which can be seen above the heads of the onlookers. A row of tall, slim pines border the backs of the tipis and lead the eye up to the north side of the Banff springs Hotel that is towering over this whole scene.

The performance, sanctioned by the organizers of Banff Indian Days, occurs inside a space of exclusion in a landscape that only half a century earlier had seen little tourism. The crowd of people kept behind the tall fence of the tennis courts poignantly indicates the economic, social, and political atmosphere of this time and the event itself. The physical and ideological segregation of the white settler and racialized bodies is obvious.

Along with performances, races and other competitive events were held. An image by Harmon from the mid 1920s entitled Banff Indian Days race (Fig. 2.3), for example, pictures a horse race on a dirt track. ${ }^{101}$ Horse hooves kick up a cloud of dust as their riders round the corner of the racetrack. Two men have taken the lead as four others follow closely behind. Spectators — tourists and locals alike — are dressed in their summer clothing, wearing sport coats with straw and felt hats. Perhaps with Kodak in hand, they watch the dusty race from beyond a fence to the left side of the image or from the interior of the racetrack. The horse race was one of the typical competitive activities in which the Ĩyãhé Nakoda and other Indigenous groups were invited to participate for

${ }^{101}$ Byron Harmon, "Banff Indian Days race,” [ca.1925], V263/NA-3324. Byron Harmon Fonds, Archives \& Library, Whyte Museum of the Canadian Rockies. 
monetary prizes. Beyond the fence around the track, tipis are visible in front of the trees covering the flat valley. A man with a movie camera stands in the background filming the race.

Another signature event at the festival was the parade of Indigenous participants, riding from their camp northeast of the town site, down Banff Avenue, and across the bridge to the Banff Springs Hotel. This part of the festival was popular and many photographs of the parade - professional and amateur-remain. Tourists and locals would stand on the sidewalk of the main street and watch the parade of Ĩyãhé Nakoda and others elaborately dressed riding equally as fancy dressed horses pass through town. Harmon's Banff Indian Days Parade (ca.1910, Fig. 2.4), for instance, shows a procession of riders typical of the parade formation, dressed in feather and fur headdresses making their way on horseback down a dusty dirt road lined with trees. ${ }^{102}$ The road looks like it is packed down from automobile tires but still rocky and rough. Rising above the road and tall pine trees towers Cascade Mountain. The riders are headed towards the town of Banff and riding away from the area below Cascade Mountain where the Indigenous Indian Days Participants camped. When I look closely at the negative, I notice that the power lines and poles on the roadside have been scratched out partially or fully. Harmon has attempted to edit out the evidence of the power lines in the photograph. The outlines can barely be seen on the scan of the negative and perhaps a print would show an even fainter record of the poles and lines. When I consult the negative, I find that the emulsion has been carefully scratched out to obscure this evidence of early twentieth century Banff. A magnified view of the negative shows tiny, deliberate lines

\footnotetext{
${ }^{102}$ Byron Harmon, "Banff Indian Days parade," [ca.1910], V263/NA-3362, Byron Harmon Fonds, Archives \& Library, Whyte Museum of the Canadian Rockies.
} 
scrapped out of the emulsion layer. Perhaps these edits have been made for the purposes of erasing the contemporary moment of the parade of riders, or for removing any reference to the modernity of the town of Banff. In either reading, the omission of signifiers of modernity, places the Indigenous riders in a previous time where, perhaps in the eyes of the tourists, they rode into Banff in such a line.

The selling of this ideal version of the national park went beyond the festival organizers' advertisements. Banff Indian Days provided an opportunity to make photographs of Indigenous people that would popularize postcards or views because of their so-called authentic subject matter. Byron Harmon was no different from other photographers who flocked to the event to capture pictures of Indigenous people off reserve performing in regalia. Harmon took advantage of the opportunity to photograph Indigenous peoples in ceremonial or pow-wow regalia on horses or sitting in front of tipis to produce commercial photographic products at a time when 'pre-contact,' romanticized views of Indigenous peoples were very popular and widely collected.

In this chapter, I have endeavored to share some of the histories of a time of great change and colonial effects in the Banff area. Within the frames of photographs of dancing, riding on horseback clothed in beautiful regalia, or a mother with her two small children, I see more than just the scene before me and in this thesis I propose ways for multifocal looking at images. One of these ways has been to present the historical context of the photographs. In her chapter, "Visualizing Native Survivance: Encounters with my Ho-Chunk Ancestors in the Family Photographs of Charles Van Schaick," Amy Lonetree places the photographs of Van Schaick in their historical context, which she presents as the visual legacy of the photographs in an effort to cement what she believes the 
photographs communicate. ${ }^{103}$ She states that viewers of photographs depicting Indigenous peoples must understand that "every encounter with the images should begin with the recognition that you are not just looking at Indians; you are looking at survivors whose presence in the frame speaks to a larger story of Ho-Chunk survivance." ${ }^{, 104}$ I echo this sentiment from Lonetree: the Harmon photographs of the Ĩyãhé Nakoda and other First Nations are important objects that have the capacity to communicate difficult histories of colonialism and Indigenous resilience and presence.

${ }^{103}$ Lonetree, "Visual Native Survivance: Encounters with My Ho-Chunk Ancestors in the Family Photographs of Charles Van Schaick," 15.

${ }^{104} \mathrm{Ibid}, 22$. 


\section{Chapter Three}

\section{Reading the Photographs}

Photographs have the capacity to embody multiple histories, which are simultaneously communicated through the many modalities of photographic meaning. This multitude of information innately embodied in photographic objects is communicated through all of their constitutive properties - material, visual, and sometimes textual. These objects also exist within a set of parameters or frames such as collections or publications, which in turn produce narratives that can influence how a photograph is read. I argue that beginning with a close visual analysis of the photograph and working outward is an important process in understanding the broader cultural, social and political contexts of the object. As outlined in the introductory chapter, this is a methodology adapted from Material Culture studies and Kopytoff's notion of the "cultural biography" of the object as translated to the photograph by such scholars as Elizabeth Edwards. ${ }^{105}$ The Harmon photographs are products of complex historical interactions and to understand these objects, I feel that it is also crucial to look closely at the point or record of that encounter. I approach this process with the understanding that the uncovering of multiple histories and disrupting dominant or conventional patterns of narrative formation is a form of intervention. As I outlined in Chapter One, the Harmon collection exists in multiple formats. These include negatives, gelatin silver prints, handtinted prints, postcards, large-scale prints and more. All of these photographic objects

${ }^{105}$ Kopytoff, "The Cultural Biography of Things: Commoditization As Process," 64-91; Elizabeth Edwards, "Objects of Affect: Photography Beyond the Photographic Image," Review of Anthropology, 221234; Elizabeth Edwards and Janice Hart, "Mixed Box: The Cultural Biography of a Box of "Ethnographic" Photographs," 47-61. 
have distinct material existences and, therefore, distinct social functions. ${ }^{106}$ I argue in this thesis that examining the social functions of photographs' material forms is integral to their reading and reception in connection to Indigenous histories and peoples. In short, they contribute to a rich "cultural biography" of the photograph.

The two previous chapters have provided social, political, economic, cultural, and historical contexts for understanding the cultural biography of the Harmon photographs. While these factors allow for a comprehensive understanding of the context of creation, they must also comprise close analyses of specific photographs. My readings of these photographs are performed through a first person point of view and reflect my research in the archives and elsewhere. I trace the sometimes multiple material lives of these photographs, examine the visual aspects contained within the images, and consider the archival and historical narratives that accompany each photographic object. Out of these examinations, I offer possible conclusions about the photographs as influenced by interdisciplinary methodologies, noting, however, that there are many possible readings of the very same objects.

\section{Narrative Constructions/Deconstructions}

While reading about the life and work of Byron Harmon in Great Days in the Rockies: The Photographs of Byron Harmon, 1906-1934, I came across an image of three young Indigenous people. ${ }^{107}$ Arranged in the centre of the frame before a grove of trees,

\footnotetext{
${ }^{106}$ Edwards, "Objects of Affect: Photography Beyond the Photographic Image," 221-234.

${ }^{107}$ Byron Harmon, "Young Stoney Indians n.d." found in Harmon, Great days in the Rockies: The Photographs of Byron Harmon, 1906-1934, 50.
} 
the three stand side-by-side in a frontal pose with their eyes directed at the camera. The image is a half-tone reproduction from a cellulose nitrate negative. All three subjects are dressed in what was probably their routine clothing of the day: the women wear cotton dresses, one in a long cardigan and the other covered in a shawl, while the man dons a hat, collared shirt, and jacket, with his pants tucked into his boots. The woman on the far left also wears a wide-brimmed hat, long beaded necklace, apron and high-laced boots; her floral print dress appears behind a gingham apron.

The central figure in the image has carefully braided hair accented with barrettes, a beaded necklace and bracelet, scarf, and plaid shawl held together with a safety pin. Carefully displayed against her stomach and cradled in her left hand is a paper fan. The fan itself, held upside down to the viewer of the photograph, bears a portrait of a nonIndigenous woman from the chest up, shoulders exposed, her curly hair in a bun with sections of hair falling at her temples. She reflects standards of settler beauty and glamour of the day. The image on the fan has the lighting and soft focus typical of Pictorialist influenced advertising images. Indeed, fans printed with advertisements were popular the during the early decades of the twentieth century produced to promote a myriad of consumer goods with an image printed or pasted on the front, and textual information about the product on the verso. ${ }^{108}$

According to archival records at the Whyte Museum, this photograph was taken at Banff Indian Days, the annual festival that I discussed in the previous chapter. But for me, this photograph stands out from many others taken at the festival because the subjects are

${ }^{108}$ Tippecanoe County Historical Association, "Advertising Fans," http://web.ics.purdue.edu/ salvo/@SEA/exhibit/advertising.asp, last modified 2008. Hand fans made of paper attached to a wooden stick became a popular mode of advertising in the early twentieth century. 
not wearing any ceremonial regalia, beadwork or headdresses typical of photographs depicting the festival. As described, images of Indigenous participants in Indian Days often showed them dressed in 'traditional' clothing or pictured them performing tasks or with belongings that reflected contemporary settler perceptions of pre-contact Indigenous life.

While this Harmon photograph appears to be a more casual likeness of three young people than those most of those produced during Banff Indian Days, it, nevertheless, is clearly constructed. The background of the photograph is non-descript and provides no context for situating the image other than recalling tropes of ethnographic photography. Regarding this, Deborah Poole states, "anthropologists wishing to use photography in the field were faced with the problem of weeding out the extraneous contexts and contingent details captured by cameras."109 One of the ways early twentieth-century ethnographers attempted to erase contexts was to photograph people in front of sheets, backdrops, or non-descript natural backgrounds like example. ${ }^{110}$ Along with the conscious control of the background, the photographer also attempted to mediate what Poole calls "the distracting 'noise' of context, culture, and the human countenance." 111 The clothing and objects worn by Harmon's sitters speak to the unavoidable inclusion of context in the photograph. As Stephanie Pratt states in "Restating Indigenous Presence in Eastern Dakota and Ho Chunk (Winnebago) Portraits of the 1830s-1860s," "The objects whose material presence disrupts the authority of the Western portrait speak without texts, constituting a mode of knowledge that is particular

\footnotetext{
${ }^{109}$ Poole, “An Excess of Description: Ethnography, Race, and Visual Technologies,” 172.

${ }^{110}$ Christopher Pinney, Photography and Anthropology (London: Reaktion Books, 2011), 41.

${ }^{111}$ Poole, “An Excess of Description: Ethnography, Race, and Visual Technologies,” 163.
} 
to the performance of a culture."112 The material presences such as the fan may "speak without texts," but they certainly speak. This mass-produced and photographically illustrated consumer product subverts conventional pictorial presentations of the Indigenous Other. Pratt goes on to say, "in paying attention to the kinds of objects each sitter displays on and about their person, we can begin to comprehend how objects can represent relationships outside and beyond the frame of the portrait." ${ }^{113}$ I would go further to say that these intrusions disrupt the ambitions of commercial photographers like Harmon who intended on selling images of Indigenous peoples that fit within the conventions set by popularized ethnographic or tourist images. Furthermore, a critical interpretation of the material culture present in a given image provides valuable alternate readings of photographs otherwise narrowly categorized in an ahistorical moment.

The image of the three figures I have described above is a half-tone reproduction I found in the book Great Days in the Rockies: The Photographs of Byron Harmon, 19061934 (1978). ${ }^{114}$ As such, it is framed by the publication's layout, accompanying text and the other photographs in the book. The accompanying caption reads "Three Young Stoney's, n.d." Great Days in the Rockies is a biography of Harmon and the illustrations are intended to be representative of his era in the Rocky Mountains. Under the subject heading "Mountain People," this photograph along with seven others that appear in the book come to stand for all Ĩyãhé Nakoda peoples. In another book, Indians in the Canadian Rockies (1985), the same photograph appears but as a hand-coloured version.

\footnotetext{
${ }^{112}$ Stephanie Pratt, "Restating Indigenous Presence in Eastern Dakota and Ho Chunk (Winnebago) Portraits of the 1830s-1860s," in Indigenous Bodies: Reviewing, Relocating, Reclaiming, edited by Jaqueline Fear-Segal and Rebecca Tillet (Albany: State University of New York Press, 2013), 27.

${ }^{113}$ Pratt, "Restating Indigenous Presence in Eastern Dakota and Ho Chunk (Winnebago) Portraits of the 1830s-1860s," 21.

${ }^{114}$ Harmon, Great days in the Rockies: The Photographs of Byron Harmon, 1906-1934.
} 
In this second appearance, the photograph's caption reads "Young Stoney Indians, photo by Byron Harmon, circa 1920, hand-coloured by Carole Harmon, 1978. Courtesy of the Whyte Museum of the Canadian Rockies." ${ }^{\text {115 }}$ All of the minute details of the young people's clothing and the surrounding plants have been carefully tinted: each tree trunk is a shade of greyish brown; the leaves a variation of moss greens with some showing a hint of yellow; the small shrub on the bottom left of the foreground has been painted a crisp green to stand out form the grasses and small plants under the subjects feet. All of the plants are shades of yellow and bright green, which makes them appear to be dry and stiff as plants of this kind often are in mountain valleys where the summer heat and sun mixed with small amounts of rain makes these small plants hearty and resilient. The dress of the woman on the left alternates light green and white with crisp white apron overtop. Her sweater is a teal blue with a black stripe down both sides; her boots are dark grey with worn, faded toes; and her hat is the colour of light grey felt. The hair barrettes of the woman in the centre are red, her scarf a rosy-pink, resting on her forest green and yellow plaid shawl. This figure's dress, a plaid pattern, shows hues of pastel blues and purples. The man's clothing has a more sombre palette; his hat lightly tinted grey, jacket a hint brown, pants have some semblance of blue, and the boots are quite light with a bit of brown. However, his collared shirt is striped with ochre and light blue, which is contrasted against a white undershirt. The hand colouring, as the caption indicates, was done by Harmon's granddaughter, Carole Harmon. In my interview with her I inquired about the choice to add colour to the image:

${ }^{115}$ Whyte, Indians in the Rockies, 111. 
When I was with Altitude ${ }^{116}$ I did quite a bit of hand colouring of black-and-white images for use in books and notecards. I found this image intriguing because of the fan in the woman's hand. As a black-and-white print it is quite gloomy so I decided to add colour. I generally do my hand colouring with Peerless Watercolours, which date from the period but this image was so dark I used Marshall's oils applied with a brush, the only time I have used them. ${ }^{117}$

The reproductions in trade publications discussed above are but two of many forms that this image takes; it exists in a multitude of formats even within the Whyte Museum Archives itself. I have encountered this image in the archives in the form of a series of exhibition prints, one of which I found hanging on the archives wall. The image is also available online through the museum's database and can be found as a reference print in a binder in the reference room of the Archives. Another print can be found in a different binder, which is used in interviews with Ĩyãhé Nakoda elders as part of the Recognizing Relations project. ${ }^{118}$ The research for that project has led to the identification of the three people in the image in question. Following those interventions, the updated caption now reads as follows:

Alma Wildman (sister of Burt Wildman), Elizabeth or Lily (sister of Jimmy Wildman) (future wife of Lazarus Wesley), Paul Poucette (Pa-to-gen) (Pa is head, To is blue, Gen is an endearment)* Information provided by Stoney Elders during the Recognizing Relations project, an archives initiative undertaken in 2014 to identify Stoney people in photographs held in the Whyte Museum Archives. Identification information also provided by 2 correction cards one filed with Jon

\footnotetext{
${ }^{116}$ Altitude Publishing was a company owned by the Harmon family that published books pertaining to the ecology, history, and stories of the Rocky Mountains.

${ }_{117}$ Carole Harmon, interview with author, March 2016.

${ }^{118}$ Recognizing Relations is a long-term community initiative and archival intervention at the Whyte Museum archives started by archives assistant, Dagny Dubois. The project has involved singular and group interviews with Ĩyãhé Nakoda elders. Dubois created binders of the images yet to be identified in multiple fonds and during the interviews from which interviewees review the images. I was an assistant at two of the group meetings held for the project. Since 2014, interviews with elders have identified individuals pictured in the Archives' photographic collections. The three people in the photograph have been named through these consultations with multiple elders and other Ĩyãhé Nakoda community members.
} 
Whyte in the Archives by visiting Stoney Elder Doris Labelle (ca.1985) and the other filed with Mary Andrews in 1992. ${ }^{119}$

While searching for traces of the original negative - number NA-3345

(Fig.3.1 ${ }^{120}$ —on the archives database by looking at digital scans, I not only came across the negative in question but also a digital scan of a variant negative depicting the same three people-NA-3344 (Fig. 3.2). ${ }^{121}$ If I had not been looking for the material traces of the photograph in the archive, I would not have found the second image, which is rarely reproduced. The two images are almost identical. They share the same sitters, framing, and composition. The small differences I found were in how the three subjects have posed their bodies, their facial expressions, and the slight blurring of Alma Wildman's face, possibly caused by her movement as the shutter was released. I also noted that the negatives have suffered different amounts of deterioration. These factors may explain why was one image privileged over the other in publications and marketing.

When consulting the reference binder, I found a print for NA-3345 (Fig. 3.1), not NA-3344 (Fig. 3.2). I also noticed that the caption of this image remains unchanged and does not reflect the identifications of the subjects. The binder was compiled in the 1980s and it was the apparent choice of an archivist to include only one of the two variant

\footnotetext{
${ }^{119}$ V263/NA-3345, Byron Harmon fonds, Archives \& Library, Whyte Museum of the Canadian Rockies.

${ }^{120}$ Byron Harmon,"E-22, Banff Indian Days" [ca.1925], V263/NA-3345. "Stoney First Nation, Alma Wildman (sister of Burt Wildman), Elizabeth or Lily (sister of Jimmy Wildman) (future wife of Lazarus Wesley), Paul Poucette (Pa-to-gen)(Pa is head, To is blue, Gen is an endearment)." Byron Harmon Fonds, Archives \& Library, Whyte Museum of the Canadian Rockies.

${ }^{121}$ Byron Harmon, "Banff Indian Days," [ca.1925]. V263/NA-3344. "Alma Wildman (sister of Burt Wildman), Elizabeth or Lily (sister of Jimmy Wildman) (future wife of Lazarus Wesley), Paul Poucette (Pa-to-gen)(Pa is head, To is blue, Gen is an endearment)." Byron Harmon Fonds, Archives \& Library, Whyte Museum of the Canadian Rockies.
} 
images. The archival narrative has, therefore, been mediated by the subjective choices of past archives staff to include one, but not the other.

I also compared the two negatives' database listings. There, one is titled "E-22 Banff Indian Days," the other "Banff Indian Days" and the identifications of the sitters can be found in the description of the object. In the article "The Colonial Legacy of the Digital Archive: The Arnold Lupson Photographic Collection,” James Opp discusses a database description of one of prairie photographer Lupson's images that has been digitized and how the traces of the origin of the image or the collection is absent from the Glenbow Museum database. ${ }^{122}$ While the same could be said for the two Harmon negatives in terms of the full context of the photograph, there are clear attempts to amend the record. The fact that the original titles remain in juxtaposition to the description identifying the subjects speaks to the layers of colonial legacies present in the archival record.

Upon consulting the physical negatives, I found that the envelopes they are housed in have contributed to the archival narratives of the photographs. On the negative envelope for the second image, NA-3344 (Fig. 3.2), handwriting in pencil indicates the number and location of the negative as well as markings that may indicate printing instructions. Again, the caption has not been updated to reflect the recent changes made in the identifications and reads "Banff Indian Days." On the top right hand corner, an inscription reads, "worst of 2." The envelope of the first image, NA-3345, also specifies the archival location, and here the image caption remains the same as the other negative;

\footnotetext{
122 James Opp, “The Colonial Legacy of the Digital Archive: The Arnold Lupson Photographic Collection." Archivaria 65 (2008): 3-19.
} 
however, another number appears-E-22. I could find no trace of a coinciding numbering system elsewhere and concluded that it may be an original catalogue number attributed by the photographer himself. The writing on the top right hand corner of this envelope says, "best of 2." Perhaps these subjective inscriptions speak to the selection process in making the reference prints I mentioned earlier, further illustrating the complicated nature of archival materials and their organization. Clearly, the archive has imposed narratives onto these photographs and these, in turn, have become part of what Elizabeth Edwards terms their material function. ${ }^{123}$ It could provide insight into why one photograph was privileged over the other in terms of its multiple commercial and published reproductions.

While I see that the material lives of this photograph raise important questions, I also find that the visual aspects of the image revel the "temporal contingencies" or "excessive details" as outlined by Deborah Poole. ${ }^{124}$ This image of the three young peoples was taken at an event that was supposed to present a particular image of Indigineity for a tourist audience — a glimpse into pre-contact life. In actuality, it shows the thoroughly modern expression of their Indigenous reality and within it, the effects of colonization and assimilation contrasted by their active experience of their own modernity. These three young people exist in their contemporary moment, disrupting the visual narrative of Indigenous presence and the so-called 'fixity' of the photographic image.

Material Lives and Movement

${ }^{123}$ Edwards, "Objects of Affect: Photography Beyond the Photographic Image," 290.

${ }^{124}$ Poole, "An Excess of Description: Ethnography, Race, and Visual Technologies," 159-179. 
Three young children, a woman, and a horse pose in front of a camera (Fig. 3.3). ${ }^{125}$ Two of the children are seated on a travois, the wooden frame used by many Indigenous groups in the plains to transport people and materials. The third child sits atop the horse hauling the travois. The woman holds the reigns, standing beside the horse. The travois is decorated with ribbons and flags and the children are wearing shirts and dresses adorned with beading and fringes. The smallest of the children-one of those sitting on the travois - returns a discerning, one could even say, grimacing look back to the camera. A young boy sits next to her, his feet dangling over the edge; he crosses his ankles and hands while turning to look at the photographer, squinting slightly in the bright light. On the saddled horse rides the third child, a girl wearing a dress and headscarf. She has turned her upper body, leaning back onto her arm so that she, too, can gaze in the direction of the camera. The standing woman also wears a dress and headscarf, along with a plaid shawl or blanket wrapped tightly around her waist. The horse has also been dressed for the occasion with a tasseled breast collar, a patterned riding blanket, and an elaborately beaded piece secured and resting on the back of the horse. Dotting the mid-ground and background of the image are tipis with bright, tightly stretched materials covering them. Empty wagons can be seen as well as a sparse grove of pine and spruce trees. Beyond the trees, a faint outline of mountains is visible. The photograph appears to be taken in a wide, flat valley. On the horizon, beyond the trees but before the mountains rise, a coulee or the banks of a riverbed appears. The sky is hazy and diffused with the sun casting short shadows.

${ }^{125}$ Byron Harmon, "Indian Travois" [ca.1920-1930], V263/NA-3140, Byron Harmon Fonds, Archives \& Library, Whyte Museum of the Canadian Rockies. 
While I had seen this photograph before in an exhibition of Harmon's photographs of Indigenous peoples, I found the original negative in the Whyte Museum archives. In the database this image is titled "Indian Travois." The full description reads, "Indian Travois, Byron Harmon (Banff, Alberta), ca.1920-1930." The original negative is cellulose nitrate, which has been digitized and is now accessible through the digital database of the archives. The negative envelope caption reads "Indian Travois, NA-713140." Further markings in pencil indicate possible developing chemical ratios. The emulsion layer shows some small scratches, abrasions and fingerprints. The sheet is warped in multiple places. While looking through the archival box where I found this negative, I identified another photograph of the same subjects, negative number NA3139 (Fig. 3.4) ${ }^{126}$ which shows the same group of people from a different vantage point. While NA-3140 (Fig. 3.3) appears to have been framed strategically for commercial purposes, omitting any other people in the background, NA-3139 (Fig. 3.4), in contrast, looks more casual. People in the background are seen standing around or sitting on horses. The children, too, appear more relaxed or casual. In short, this second image is less typical of the more carefully choreographed photographs that would have been marketed commercially.

The principal image described above appears in the archival collection again as two postcards, V263-pg-bw-536 and V263-pg-bw-536-1 (Fig. 3.5 ${ }^{127}$ and 3.6 ${ }^{128}$ ). Both are faded and damaged; one of them (Fig. 3.5) shows evidence of having been folded down

\footnotetext{
${ }^{126}$ Byron Harmon, "Indian Travois” [ca.1920-1930], V263/NA-3139, Byron Harmon Fonds, Archives \& Library, Whyte Museum of the Canadian Rockies.

${ }^{127}$ Byron Harmon, "Indian Travois," V263/PG-bw-536, Byron Harmon Fonds, Archives \& Library, Whyte Museum of the Canadian Rockies.

${ }^{128}$ Byron Harmon, "Indian Travois," V263/PG-bw-536-1, Byron Harmon Fonds, Archives \& Library, Whyte Museum of the Canadian Rockies.
} 
the middle. The emulsion is peeling away from the crack caused by the fold and residue of dirt and fingerprints cover the front of the postcard. The crease is evident on the back of the card, which also shows significant wear. An archival item number has been written on the top left hand corner and "284B" scrawled in grease pencil across the area of the verso usually reserved for a written message. The second postcard is in relatively better condition but a large portion of the top right hand corner has been removed or lost; this missing piece has nearly excised the woman from the image. The item number has been recorded at top on the back of the card in pencil in the same manner as the first. On the back of both postcards black text is printed with "Post Card, Made in Canada, Along the line of the Canadian Pacific Railway, Photographed and Copyrighted by Byron Harmon, Banff, Canada." Like "Indian Travois V263/Na-3140," both of these postcards have been digitized and can be found through the archives database. From a purely visual point of view, they are the same image; however, they are not the same object. One (Fig 3.5) appears to have more signs of deterioration because of the discolouration seen on the emulsion layer. The other has been severely damaged through what appears to be deliberate cutting or mishandling of the delicate print.

In research into the archival fonds of other Banff residents known to collect Harmon images, I located yet another example of the travois image. Again, the three children and woman appear with the horse, tipis, wagons, and mountains, but the image now takes the form of a hand-coloured lanternslide (Fig. 3.7). ${ }^{129}$ This slide has a square orientation, cropping out the edges of scene. The beadwork on the clothing and adornments on the horse are coloured in bright blues and oranges. The grass is tinted a

\footnotetext{
${ }^{129}$ Moore Family Fonds, [Unidentified woman and children with travois], 1899 - 1927, V439-ps321, Moore Family Fonds, Archives \& Library, Whyte Museum of the Canadian Rockies
} 
light yellowish green and the sky two shades of intense aquamarine blue. Lanternslides were often tinted with transparent colour dyes or paint to give an illusion of full colour photography. ${ }^{130}$ This lanternslide is held in the Moore Family fonds. Philip and Pearl (nee Brewster) Moore resided in Banff, Alberta and in the Yoho Valley, British Columbia. They were prominent and active members of the community in business and social affairs. ${ }^{131}$ It is possible that Philip Moore had the slide made by Harmon's studio, had it made by a publisher in the Eastern United States, or received it from Mary Schäffer Warren who was known to make slides from Harmon's images. The slide was likely used for private viewing and to illustrate lectures Moore gave. During the 1920s and early 1930s, he lectured extensively. The lanternslide has no markings to indicate a title or any other information relative to the object or the image. It appears to have been homemade with the cover plates taped together with black tape. The frame inside the front cover tape is black paper with a silver design. A red adhesive sticker has been placed on the bottom of the slide. Indicating importance or for inclusion with a certain lecture, perhaps. Lanternslides were commonly produced either by publishing companies or by individuals who had use of the proper materials. Commercially available glass plates were sold for making the necessary transparency ${ }^{132}$ and once the transparency was created, the plate was secured against another clear glass plate for protection. A dark paper frame was often placed on one side of the transparency to aid in the projection process. The plates were

\footnotetext{
${ }^{130}$ George Eastman House "Lantern Slide" http://notesonphotographs.org/index.php?title=Lantern_Slide

${ }^{131}$ M307 / V439, Moore (Family) Fonds. Archives \& Library, Whyte Museum of the Canadian Rockies

132 Thomas Craddock Hepworth, The Book of Lantern (New York: Arno Press, 1978), 115.
} 
then sealed together using an adhesive tape. ${ }^{133}$ Slides made by publishers often carried the name of the company on one side of the slide.

This 'travois' image is included in a subset of Harmon's collection that depict Indigenous subjects. In addition, along with fifteen other photographs from Harmon's hand tinted images of Indigenous peoples, this image is sold as a special edition print on the "Byron Harmon Photos" website (Fig. 3.8) ${ }^{134}$ The website advertising states: "25 prints from each of the original hand-coloured photographs, rephotographed, retouched and printed by Carole Harmon numbered and signed by Carole Harmon;” and, "Reproduced from 16 vintage hand coloured photographs. Rephotographed, retouched and reproduced as exhibition archival quality prints at the size of the originals by Carole Harmon.."135 Like the tinted lanternslide in the Moore collection, this photograph has been hand-coloured. Compared to the palate of blues and oranges of the slide, the hand tinting in this image features dark green trees, a hazy grey, yellow and blue sky, and the grass is a mix of greens and browns. The skins or fabric of the tipis and the seat of the travois are a light beige. The clothing worn by the children is coloured with vibrant turquoise, moss green, and white. In contrast, the woman's garb is subdued but delicately painted. The top of the image has been cropped, cutting off the top of the tipi behind the subjects and erasing any reference to the mountain ranges in the distance.

${ }^{133}$ John Barnes, "Classification of Magic Lantern Slides for Cataloguing and Documentation," Magic Images: The Art of Hand-Painted and Photographic Lantern Slides, eds. Dennis Crompton, David Henry, and Stephen Hebert (London: Magic Lantern Society of London, 1990) 84.

${ }^{134}$ Byron Harmon, S06 Stoney Family and Trava (travois), Stoney Limited Edition Portfolio, http://www.byronharmonphotos.com/editions/stoneyLTD/index.html, last modified 2013, used with permission by Carole Harmon.

${ }^{135}$ Carole Harmon, "Stoney First Nation Portraits," http://www.byronharmonphotos.com/editions/stoneyLTD/index.html, last modified 2013. 
While on vacation in August 2015 in the Columbia Valley, in British Columbia, I encountered the image once again, on page six of a local newspaper, the Columbia Valley Pioneer. An accompanying caption states, "In this image, dated 1922, a woman stands with her children at Four Point, in Invermere. Two of the children sit in a travois and the other is riding a horse. ${ }^{\prime 136}$ The composition appears to be the same as the postcard image with the slight cropping of the top of the photograph; however, the postcard catalogue number is not present, suggesting that perhaps this reproduction came from a commercial print rather than a postcard. Since there appeared no other differences between this image and the postcards in the Whyte Museum, this was a notable discrepancy. The caption states that the photograph was taken in Invermere, British Columbia, where Harmon owned a home and a campground in Windermere, a neighboring community in the Columbia Valley. ${ }^{137}$ If true, this identification complicates the archival and historical narrative attached to the image. If it had indeed been shot in Windermere or Invermere and not in the Bow Valley, who are the sitters? Why was this scene or camp set up in the Columbia valley? How does this information change the existing narrative of his photographs?

Lastly, I found the same image in Hugh Dempsey's 1998 popular history Indians of the Mountain Parks. Dempsey's caption reads, "These Stoney Indians travelled for several days by wagon in 1922 to attend a fair in the Windermere Valley with their one time enemies, the Kootenays. The horse travois, easily assembled for a parade, was later

\footnotetext{
136 "Historical Lens," The Columbia Valley Pioneer, August 28, 2015, 6.

${ }^{137}$ Harmon had a home Windermere and Wilmer British Columbia. He also owned a campground in Windermere. Interview with Carole Harmon, March 21, 2016.
} 
taken apart and the poles used for their tepee." ${ }^{\prime 138}$ The negative for the image was not sourced from the Whyte Museum, but from the archives of the Glenbow Museum. ${ }^{139}$ If Dempsey is correct in his claim that this image was made at a fair in Windermere and the subjects are Ĩyãłé Nakoda, this changes my original view of the photographs as being taken at Banff Indian Days. It may also amend the archival and historical narratives attached to the image in that this disrupts the assumption that all of Harmon's photographs of Indigenous people were taken at only one event.

Once again, the multiple photographic forms of this single image each have their own social function. Each photographic object I encountered in the archives or on the database performs a different material and social function that affects their reception and reading. The negative served as the original document from which almost unlimited copies could be made. Postcards are the commodified objects designed for distribution to any number of places. The lanternslide is the photograph that is shown publicly and made for projection while mediated by whomever is sharing it. A hand-coloured reproduction emulates a product made by the original photographer and is made available for a contemporary audience. An image in the newspaper becomes a colloquial object that is seen by most in passing and likely thrown away. In the ethnographic text, the photograph appears as an illustration for the author's purposes.

The embodied engagement with photographs as objects in their many material forms, including the multivalent example I have just described, can provide important contextual and historical readings. As Edwards states, "photographs, as objects defined in

${ }^{138}$ Hugh Dempsey, Indians of the Rocky Mountain Parks (Calgary: Fifth House Publishing, 1998), 35 .

${ }^{139}$ Glenbow Museum accession number NA-1135-17. 
part by their repurposing, are objects with active biographies in a constant state of flux." ${ }^{\prime 10}$ These photographs, in their respective material incarnations demonstrated the multitude of materials and therefore the possibility of multiple meanings and receptions based on the social material functions of each individual photograph. One negative spurred this complex chain of photographs. And, in turn, each resulting print, reproduction or slide has its own material properties that impact reception. A negative to a postcard, a negative to a print to a newspaper article, a negative to a print to a hand coloured lanternslide, a negative to a hand-coloured print to a digital image: these interrelated material lives of the photographic objects comprise part the cultural biography of the Harmon photographs.

\section{Text/Image/Material Relationships}

A tipi stands in a grassy valley. (Fig. 3.9) ${ }^{141}$ The tipi is painted with geometric patterns: a line encircles the smoke hole with small circles above; a sun symbol is painted near the top of the tipi; three parallel bars wrap around the whole bottom section with four triangles lined up to the left of the entrance above the bars, their points echoing the mountain peaks in the background; circle shapes rise up in a line above the triangles; and two parallel lines frame the tipi entrance. In front of the tipi stand two people: a man and a woman. The man appears directly in front of the structure, looking straight ahead at the camera with arms hanging by his sides. His hair is in braids with a small bead or shell

${ }^{140}$ Edwards, "Objects of Affect: Photography Beyond the Photographic Image," 225.

141 Byron Harmon, "506.Stoney Indian and Squaw” [ca.1915-1925], V263/NA-3258, Identified as Mr. and Mrs. Job Stevens and Job has been identified as Wi-wa-kun through the Recognizing Relations Project. Byron Harmon Fonds, Archives \& Library, Whyte Museum of the Canadian Rockies. 
above his left ear. He wears multiple necklaces along with a fur collar that hang from his neck and shoulders down past his waist. The fur appears to be light brown and the collar is adorned with nine circular mirrors, each about the size of the palm of a hand. On his extremities, he wears beaded armbands, beaded and tasseled gloves, and beaded leggings; all of the beadwork is comprised of geometric patterns. I try to imagine what colours they might be: perhaps bright white with red and blue. The woman stands to his left, facing the camera with a slight smile and tilt of her head. Her hair is long and braided, adorned with round, bright shells and ribbon or some kind of fabric or hide. Around her neck hang beaded and woven necklaces, while across her chest the fabric of her long-sleeved dress is decorated with darts and buttons, visible beneath the necklaces. Her beaded gloves have long tassels with vegetal and geometric beaded patterns. A plaid blanket drapes across her left arm. Behind the two people and the tipi, a grove of bushes and deciduous trees frame the left foreground and mid-ground of the image and extend to the background in a diagonal vanishing point. The end of the grove reveals some rail cars moving in the distance. Rising high above the scene is Cascade Mountain, ${ }^{142}$ the treecovered lower slopes ascending to meet the jagged, rocky peaks. On the left edge of the picture frame there appear to be some smaller poles erected for another structure, while in the foreground, wooden poles lay in the shallow grass, obscured by writing in white pencil.

Handwriting, scrolled across the negative itself, marks the bottom edge of the image and textually frames the whole scene. It reads-“506. Stoney Indian and Squaw.”

${ }^{142}$ This mountain is commonly seen in the background of photographs from Indian Days as the camping area for the Ĩyãfé Nakoda and others was made on the flats near the base of the mountain, at the edge of town. 
(fig.3.9) ${ }^{143}$ This was the caption given by the photographer, most likely for the purposes of making postcards. The number indicates the catalogue or order number of the image. ${ }^{144}$ Similarly, the negative envelope bears the inscription "Stoney Indian \& Squaw 506, V263/NA-71-3258" written in pencil, as well as other markings indicating development or other chemical ratios. The negative inside the envelope is cellulose nitrate in $5 \times 7$ format a standard size for this photographic process. ${ }^{145}$ The negative is dry, fragile and warped in multiple places. The emulsion layer shows several marks from abrasions. The subjects have been identified through the Recognizing Relations project as Mr. and Mrs. Job Stephens or Stevens and Job has also been identified as Wi-wa-kun. ${ }^{146}$

To understand the impact of text on the image layer of the photograph, I turn to Roland Barthes' essay “The Rhetoric of the Image.” In this early statement on photography, Barthes states, “...various techniques are developed intended to fix the floating chain of signifiers in such a way as to counter the terror of uncertain signs; the linguistic message is one of these techniques." ${ }^{147}$ Barthes goes on to state that text can serve either as an "anchor," tethering an image to a meaning, or "relay," providing linkages in a sequential narrative. Through the inclusion of language on the surface of the image, the maker is signaling what the viewer needs to know about the image. In this

${ }^{143}$ Byron Harmon, "506.Stoney Indian and Squaw” [ca.1915-1925], V263/NA-3258. Identified as Mr. and Mrs. Job Stevens. Job has also been identified as Wi-wa-kun, Byron Harmon Fomds, Archives \& Library, Whyte Museum of the Canadian Rockies

${ }^{144}$ Catalogue for commercial ordering or the photographer's own organization system, not in the Whyte collection.

${ }^{145}$ Valverde Valdés, Photographic Negatives: Nature and Evolution of Processes, 20.

${ }^{146}$ Dagny Dubois, email message to author, April 20, 2016. The identification process is constantly evolving which results in variations or changes in some identifications. This is true in the case of Wi-wa-kun (Job Stephens/Stevens). The sources for the spellings and verifications of identifications can sometimes have discrepancies between them. I will refer to Stephens/Stevens as Wi-wa-kun from this point on. The identifications are not fixed and spelling often varies as with Stevens and Stephens.

${ }^{147}$ Roland Barthes, "Rhetoric of the Image," Image, Music, Text (New York: Hill and Wang, 1977), 39. 
case, the brief caption "Stoney Indian and Squaw" others the subjects of the image; they are not identified as individuals but instead stand for all "Stoneys" while underscoring their difference from a privileged whiteness. They are categorized and homogenized by language and meanings of the words in settler society. Both words, "Indian" and "Squaw" indicate a generational distance and use language to debase. In short, they nonetheless place the couple in the photograph into essentialized categories while disregarding their individual identities.

Within the Whyte Museum, the context of this image, like the others I have discussed in this thesis, has been framed by digitization and new research efforts that mediate the issue of outdated language and the lack of identifications. The database describes the photograph as "Mr. \& Mrs. Joe Stevens at Banff Indian Days Stoney First Nation." The caption has been updated to reflect the identification of the couple. However, the original title provided by the Harmon family or Museum staff -"506.Stoney Indian \& Squaw" [ca.1915-1925]—remains visible, acknowledging the historic layers of meaning and settler colonial oppression.

The image also exists as a postcard. The location of the postcard in the archives is V263-pg-bw-506. (Fig.3.10). ${ }^{148}$ It is a silver gelatin postcard print and on the back of the card is Harmon's postcard stamp reading "Post Card, Made in Canada, Along the line of the Canadian Pacific Railway, Photographed and Copyrighted by Byron Harmon, Banff, Canada." The postcard, like the negative from which it was produced, has the original title written across the front of the card. I cannot ignore the material difference between a

${ }^{148}$ Byron Harmon, "Stoney Indian and Squaw," V263/PG-bw-506, Identified as Mr. and Mrs. Joe Stevens, Job has also been identified as Wi-wa-kun through the Recognizing Relations Project. Byron Harmon Fonds, Archives \& Library, Whyte Museum of the Canadian Rockies. 
negative and a postcard: the postcard has the same image as the negative but a different material purpose and, therefore, a different message. Returning to Barthes, as he explains in the essay "The Photographic Message," "whatever the origin and the destination of the message, the photograph is not simply a product or a channel but an object also endowed with a structural autonomy." ${ }^{, 149}$ While Barthes is referring here to a press photograph, I would argue a tourist postcard functions similarly. He continues to say that the photograph is at the same time "constructed, chosen, composed," and "this same photograph is not only perceived, received, it is read, connected more or less consciously by the public that consumes it to a traditional stock of signs." ${ }^{\prime 150}$ The stock signs that this image is connected to are those of "Indianness," which I think made this photograph purposefully marketable as a postcard. The 'success' of such a photograph relies on the premise that photographs communicate "denotative" or indexical but in reality, are always "connotated" 151 This factor is compounded by the addition of the text, which in turn reinforces the notion that the subjects are not individuals but mere 'types.' In addition to the image and text, the postcard as an object is bound by its function as a commodity meant to be bought, sent, and consumed.

\section{Portrait as Encounter}

Harmon also photographed Wi-wa-kun, one of the subjects of the photographs discussed above, in his Banff studio (Fig. 3.11). ${ }^{152}$ This studio portrait shows Wi-wa-kun seated in front of a neutral, white backdrop in a manner familiar to ethnographic images.

\footnotetext{
${ }^{149}$ Roland Barthes, “The Photographic Message,” Image, Music, Text (New York: Hill and Wang, 1977), 15.

${ }^{150}$ Barthes, “The Photographic Message," 19.

${ }^{151}$ Ibid, 15-31

${ }^{152}$ Byron Harmon, “505. Bearskin Indian,” V263/NA-3119, Byron Harmon Fonds, Archives \& Library, Whyte Museum of the Canadian Rockies. Identified as Wi-wa-kun and Job Stevens/Stephens.
} 
I can see the shadows cast on the blanket from where it has been pulled taut near the bottom of the frame. His eyes are focused beyond the frame and his expression appears relaxed. Wi-wa-kun wears his hair in braids that rest on his chest, adorned with beads and with one round white shell near his left temple. Around his neck hang two beaded necklaces, and the same fur collar he wore in the previous image extends down his chest to rest on his lap, decorated with circular mirrors or glass pieces. Armbands are clasped around each of his biceps, beaded with light coloured beads in a dark square motif. He rests his hands in his lap, sheathed in gloves delicately beaded with geometric patterns and featuring tassels on the outside edges. He also appears to be wearing a fabric sort of loincloth. In the previous image, he was wearing a long sleeved shirt and pants with leggings; in this image, he is not. Bare skin shows beneath the armbands, gloves, and fur collar. Who is to say why in this image he is dressed differently from the way he appears in the scene outdoors? Perhaps he wears it over his other clothing when it is not being worn in its ceremonial or social context?

Obscuring his right leg and calling attention to the bottom of the photographs is the caption, "Bearskin Indian.505." Again, this caption anchors meaning, drawing attention to Stephens' clothing and imbuing his figure with a sense of the exotic, even encouraging an ethnographic reading. This caption remains as the title in the museum database description today. The image is dated ca.1915-1925. As with the photograph with his wife, the original title was made by Harmon or a member of the Harmon family. Iyãhé Nakoda Elders made the new identification during the Recognizing Relations project, which identified him as Wi-wa-kun and Job Stevens/Stephens. It is curious to me that despite the multiple photographs taken by Harmon in two locations, he has still 
neglected to use Wi-wa-kun's real name and instead describes him impersonally and degradingly as "Indian".

This photograph is similar in composition and execution to Harmon's other glass plate studio portraits. It may have been a copy negative made from the glass negative that no longer survives. The original glass negative would likely have been a gelatin dry plate negative, a process used from approximately 1878 to 1925 . Such glass plates were purchased from a manufacturer ready-to-use with no need to prepare the glass plate ahead of time. ${ }^{153}$ The negative envelope reads: "Bearskin Indian 505, V263/ NA-71-3119," along with other markings in pencil like $5 \times 7$ cellulose nitrate negative, and "Can't find orig." Looking at the negative and negative envelope piques my suspicion that the original image was made with a glass negative. According to the envelope, the original glass negative is missing. There are indications that the image seen in the cellulose nitrate negative is a copy of a glass negative. I could see the thickness of the glass edge on the left side of the negative and there are two small breaks in the original glass negative. On the right side, a small piece of the emulsion of the glass negative appears to have flaked off, the indication of which does not show on the emulsion of the sheet and therefore was a part of the deterioration of the glass negatives silver gelatin emulsion. The caption that is written on the image appears on the glass negative and not the nitrate negative. It appears that part of the glass plate's emulsion was originally damaged by adhesive tape on the right side of the image.

I find this photograph of Wi-wa-kun significant for the material traces found within the image itself, but also because it is the only studio portrait I look at in this thesis.

${ }^{153}$ Valdés, Photographic Negatives: Nature and Evolution of Processes, 14. 
While the other photographs I have discussed contain obvious compositional constructions and were composed with a commercial audience in mind, the studio portrait brings with it a different set of rules. Sitting for a portrait seems like a benign activity, however, in the context of photographs of Indigenous peoples, the studio image is, as Stephanie Pratt reminds us, "saturated with pre-given (Western) expectations of its function and purpose" ${ }^{, 154}$ In this case, the probable intent for this image was a commercial print or postcard. While the visual and textual traces of the photograph's original social function may remain, I believe this portrait has been given a new capacity for communicating multiple layers of meaning. In conjunction with the new archival description, this photograph presents both the historical resonance of a photographic encounter and new discourses re-contextualizing images of Indigenous peoples. The recognition of the complexity of this type of colonial relationship comprises an important aspect of the cultural biography of the Harmon photographs.

\section{Conclusion}

Singular photographs or images are not all that they seem, I feel that there is always a possibility of multiple material traces - even in cases of unique objects such as daguerreotypes or tintypes. The nature of photography allows for the reproduction of the likeness of even another photographic object. In reality they are likely one of many variants in existence. Photographs are ubiquitous in twenty-first century society; however, due to digital technologies, earlier material based formats are easily ignored. I have

\footnotetext{
${ }^{154}$ Pratt, "Restating Indigenous Presence in Eastern Dakota and Ho Chunk (Winnebago) Portraits of the 1830s-1860s," 19.
} 
endeavored to show how one image can have many material forms and visual variances and the examination of both aspects, allows for multi-layered readings and understandings. In the context of photographs of Indigenous peoples this process is necessary for uncovering the complex histories of their making, their distribution, their archival context, etc. Ultimately, I argue that it is integral to the writing of a nuanced, comprehensive cultural biography of the Harmon photographs. 


\section{Conclusion}

This thesis creates a space in which to explore the complex nature of photographic histories, and also proposes new ways of engaging with settler photographic representations of Indigenous peoples. Within this engendered space I have argued that historical settler photographs of Indigenous peoples require a method of analysis that privileges the use of interdisciplinary methodologies comprising a cultural biography of the photographs. In short, I have demonstrated how the employment of multiple modes of inquiry is required for deep, nuanced readings of photographs. This approach entails performing a cultural biography of the photographic object and, through it, uncovering layers of meaning through multivalent analysis. In all, I have emphasized the importance and usefulness of these methodologies — but what meaning do they provide?

Photographic meaning is always complex and fluid. Throughout this study, I have argued that there are multiple possible readings of a single photograph. I have also shown that photographs embody histories through their visual, material, and textual properties. Close readings of photographs expose these multiple histories and decentre master narratives or truth-claims. The readings I have provided here challenge conventional notions that photographs of Indigenous subjects only have the capacity for objectification; instead, I have tried to resist a belief in photographic fixity by showing multiple readings and suggesting that they can also depict Indigenous presence. In sum, they also contest the historical settler narrative of the Canadian West as an uncivilized wild place in need of settlement and colonial intervention. 
Just as the subjects of the photographs resist static positions, the photographic objects themselves are also capable of embodying a multiplicity of material forms and meanings. The full reading of a photographic object necessitates the examination of its material properties, which, as demonstrated in this thesis, can reveal the importance of affect, reception, and interaction. The close readings of an object in this way expose layers of interaction that contribute to the creation of photographic meaning. Every scratched negative, each creased postcard, every caption etched out of the emulsion, and every reproduction, reveals the human interaction with the objects and tells a narrative of how a photographic object has been used and perceived and what importance it has been given. This is doubly true within a collection, such as the Harmon fonds, where comparisons between photographic objects can reveal unspoken narratives. When understanding these meta narratives told by the objects themselves, we can bring a range of perspectives in which to view the photographs in order to understand what they have represented through time.

Perhaps the most significant result of adopting this mode of analysis - the cultural biography of the object - is creating a space for the sitters in the photographs to 'speak.' They speak to the imperial colonial efforts of the settler state but they also present Indigenous resilience and cultural continuity. This is an important realization to come to and to communicate to viewers - the photographs can depict difficult histories, survivance, and all other stories in between.

I want to reiterate that the approach I have demonstrated in this thesis is intended to be an open-ended engagement with the photographs and one that does not privilege any singular reading or monolithic research outcome. This type of engagement traces 
back to my self-reflexive negotiation with the photographic objects. By including my voice and leading the reader through the cultural biography process, I am enacting a form of ethical settler engagement. The transparency of my interactions with the photographs and my readings has allowed for the photographs to speak beyond and conclusions I have made about any specific details.

The goal of this thesis is to explore how a first impression of an image can change dramatically once there is closer investigation. To perform analyses that could provide some understanding of the contexts of the making and the nature of the complicated relationship between the initial photographic encounter and the multiplicity of subsequent reception. When I first saw Harmon's photographs of Ĩyãhé Nakoda peoples, I saw them from only one perspective - as negative representations. I focused on their production by a commercial photographer who profited from freezing his subjects in an ahistorical past - a notion that was accepted and expected of his settler tourist audience. They may have begun with that intention, but even from the moment of the photographic encounter, Harmon's images were and are far from static. I also did not realize the capacity of a photograph to speak to difficult social and political issues. For example, the analyses of these images acknowledges and draws attention to the historic fact of Indigenous subjugation through settler economy, government, and settlement. These photographs speak to this as well. Photographs can be a way to bear witness to these difficult histories most importantly for Indigenous communities but also for settlers who are unaware of this history and continuing legacy of colonialism in Canada.

An important addition to the historic and methodological research at the core of this study would be an examination of the rampant cultural biases on the Internet, and 
particularly in social media. In my research I found my self-scouring webpage after webpage. I found countless websites or pages of digital traces of many historical photographs of Indigenous subjects. I found many Harmon photographs, some I had never seen before, in digitization of private photographic collections as well as on websites where people had made on-line assemblages of photographs of certain subject matter or photographic type. With pages such as Pinterest or self-published blogs focused on this subject, the Internet has become an accessible space for anyone wishing to 'collect.' ${ }^{155}$ No longer do collectors need to find physical objects through auctions, books, or any other form accumulating objects. I think of this practice as virtual collecting - these practices of collecting are at once enticing and disconcerting. The Internet and the digital technologies that support it are a new frontier of collecting and modes of display. It is also a new frontier of photographic objectification where tenuous operations of distribution, narrative formation, and perpetuations of stereotypes and misconceptions are free to run unchecked. Narratives of the 'vanishing race,' cultural homogenization, essentializing language and visual categorization are rampant on these sites. These digital collections have no checks and balances system to mediate the narratives created in these virtual spaces. I feel that extending the methodological approach of this thesis could lead to important discussions of the social, material, and representational function of digital photographs or the digital traces of photographic objects.

${ }^{155}$ Pinterest is a social networking site in which user create virtual collections of images, objects, videos, ideas etc. These collections of 'pins' are shared with other users of the platform. The sources of the collections are other user collections or content from other websites. 
In addition to the Internet and social media, the digitization of photographic collections is also an important point of examination. The close examinations of the material properties of photographs becomes complicated by the digitization process of scanning photographs. In "Photographic Materiality in the Age of Digital Reproduction," Joanna Sassoon describes a scan of an image as a "digital shadow ... [that] obscures the carefully documented balance of power between materiality and context that is critical to the determination of photographic meaning." ${ }^{, 156}$ The scans are not only an indexical link to the negatives from which they are derived, they are consulted through the database and sorted by an image titled that does little to further the understanding of the photograph. The mobility and traces of the photographs change dramatically once they become digitized. These traces are important to the social work and material functions of the photographs - part of the cultural biography that was beyond the scope of my thesis project but certainly an extension of this work through the methodological approach I have taken.

I see my investigation or intervention into the Harmon fonds as the first step in a series of other projects engaging with collections of historical photographs representing Indigenous peoples. The self-reflexive methodology employed here opens a door for more collaborative explorations. The inclusion of oral histories into the reading of the photographs is an important step to provide access to the photographs for Indigenous communities through the process of the interviews and on going interaction. The Recognizing Relations project at the Whyte Museum has already started undertaking this

156 Joanna Sassoon, "Photographic Materiality in the Age of Digital Reproduction," in Photographs Object Histories, edited by Elizabeth Edwards and Janice Hart (New York: Rutledge, 2004), 201 . 
work with Ĩyãhé Nakoda communities. With the incorporation of oral history or community engagement the multiple histories and fluid meanings of the photographs could be further revealed. My hope is that I can expand this study to engage with the Recognizing Relations project. The inclusion of Ĩyã hé Nakoda voices into the cultural biography of the Harmon photographs is an important next step.

By interrogating historical objects or representations there is much to be learned about the past, but I feel that it is important also to imagine how these issues translate to a contemporary engagement. After all, historical analysis always tells of the past through the present. Analyzing photographs of Indigenous peoples to expose multiple layers simultaneously points to cultural inequities today and challenges our relationship to the present. When we attempt to write histories in ways that are non-linear and multi-facetted, we may then begin to reconcile the distances that obscure our readings and understandings of the past with contemporary society. 


\section{Illustrations}

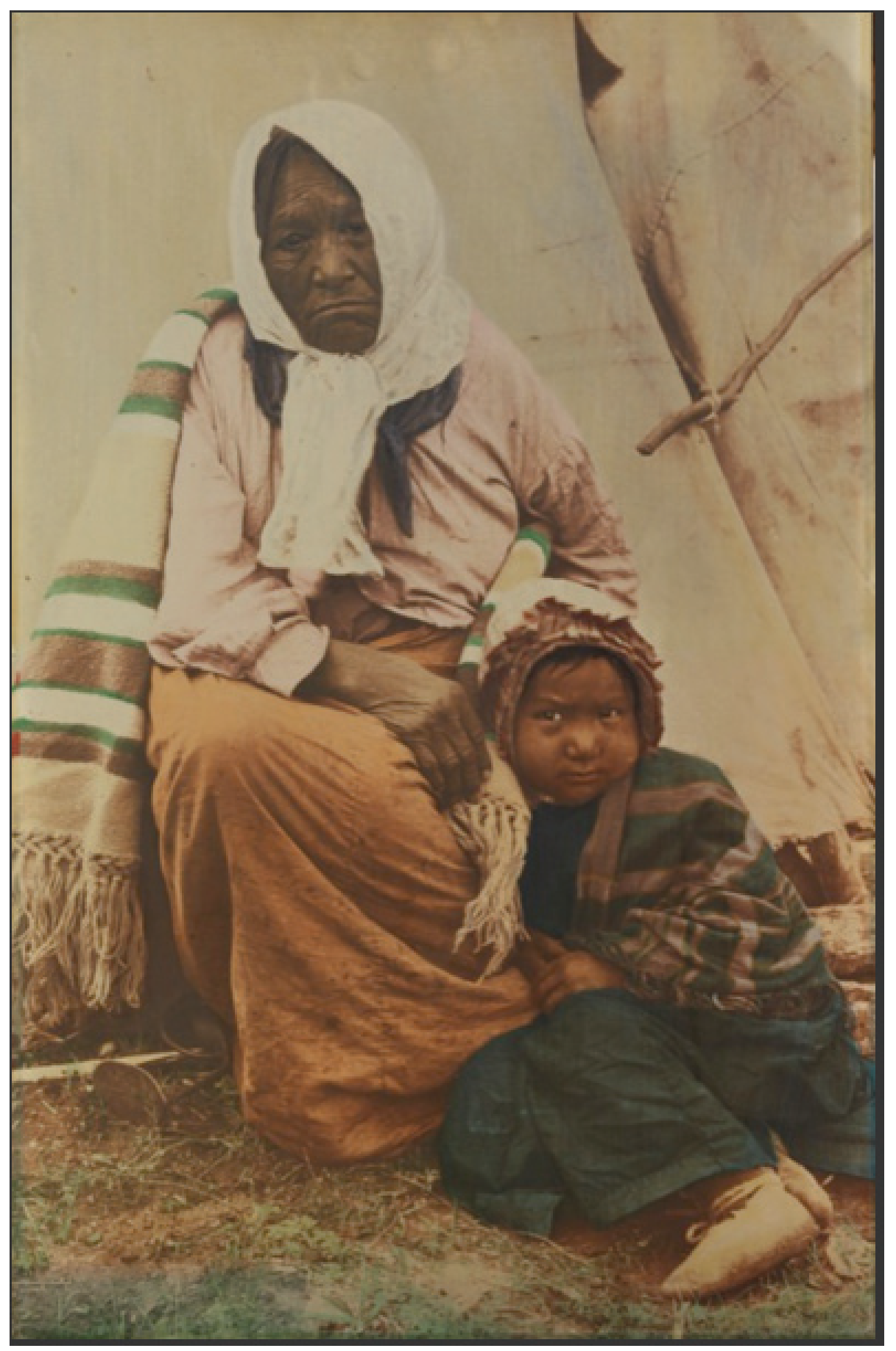

Figure INTRO.1 Byron Harmon, "S08 Grandmother and Child," Stoney Limited Edition Portfolio. http://www.byronharmonphotos.com/editions/stoneyLTD/index.html. Last modified 2013. Used with permission by Carole Harmon. 


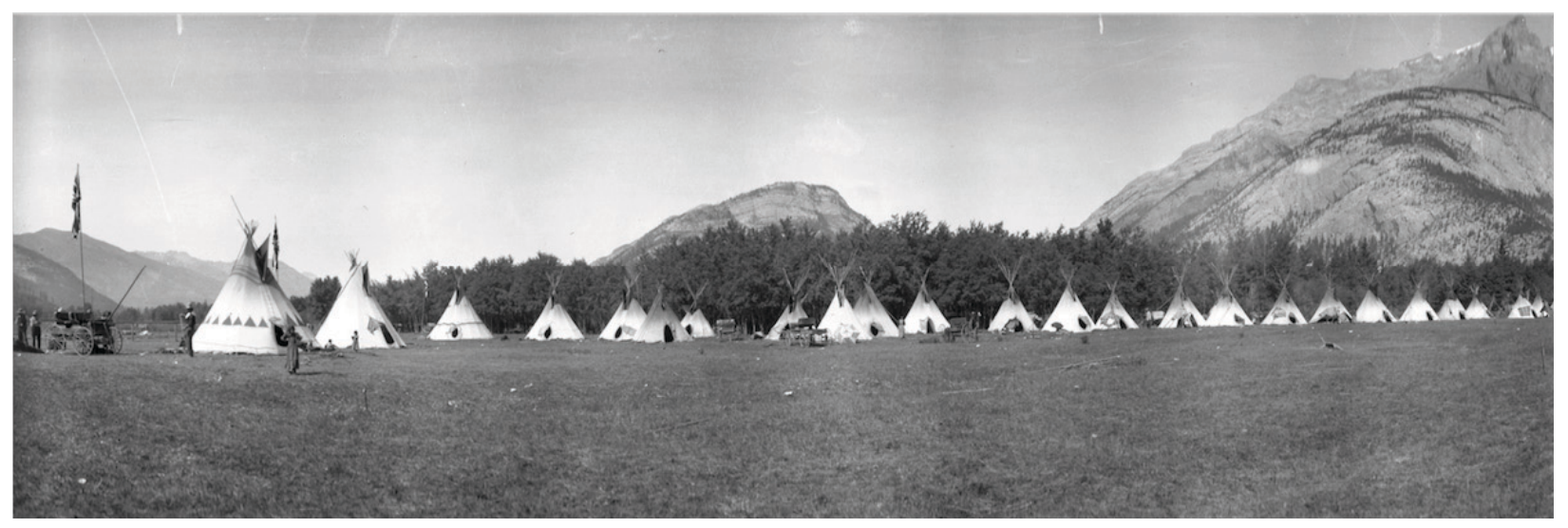

Figure 1.1 Byron Harmon, "Untitled: [teepees]" [1910], Described as "Site of Banff Springs Hotel golf course," V263/NA-6379, Byron Harmon Fonds, Archives \& Library, Whyte Museum of the Canadian Rockies.

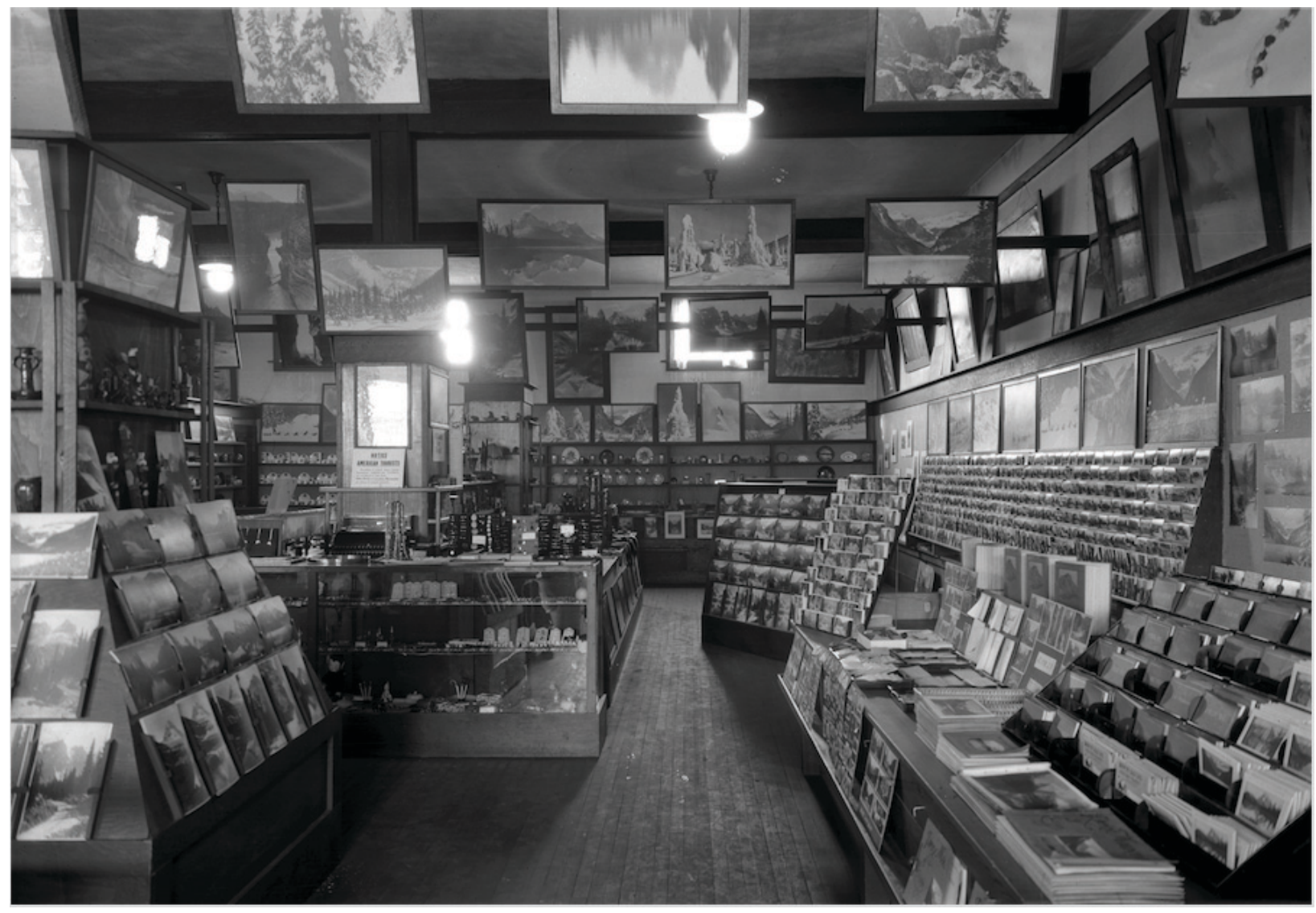

Figure 1.2 Byron Harmon, "Harmon Store," [between 1903 and 1942], V263/NA-4221, Byron Harmon Fonds, Archives \& Library, Whyte Museum of the Canadian Rockies. 


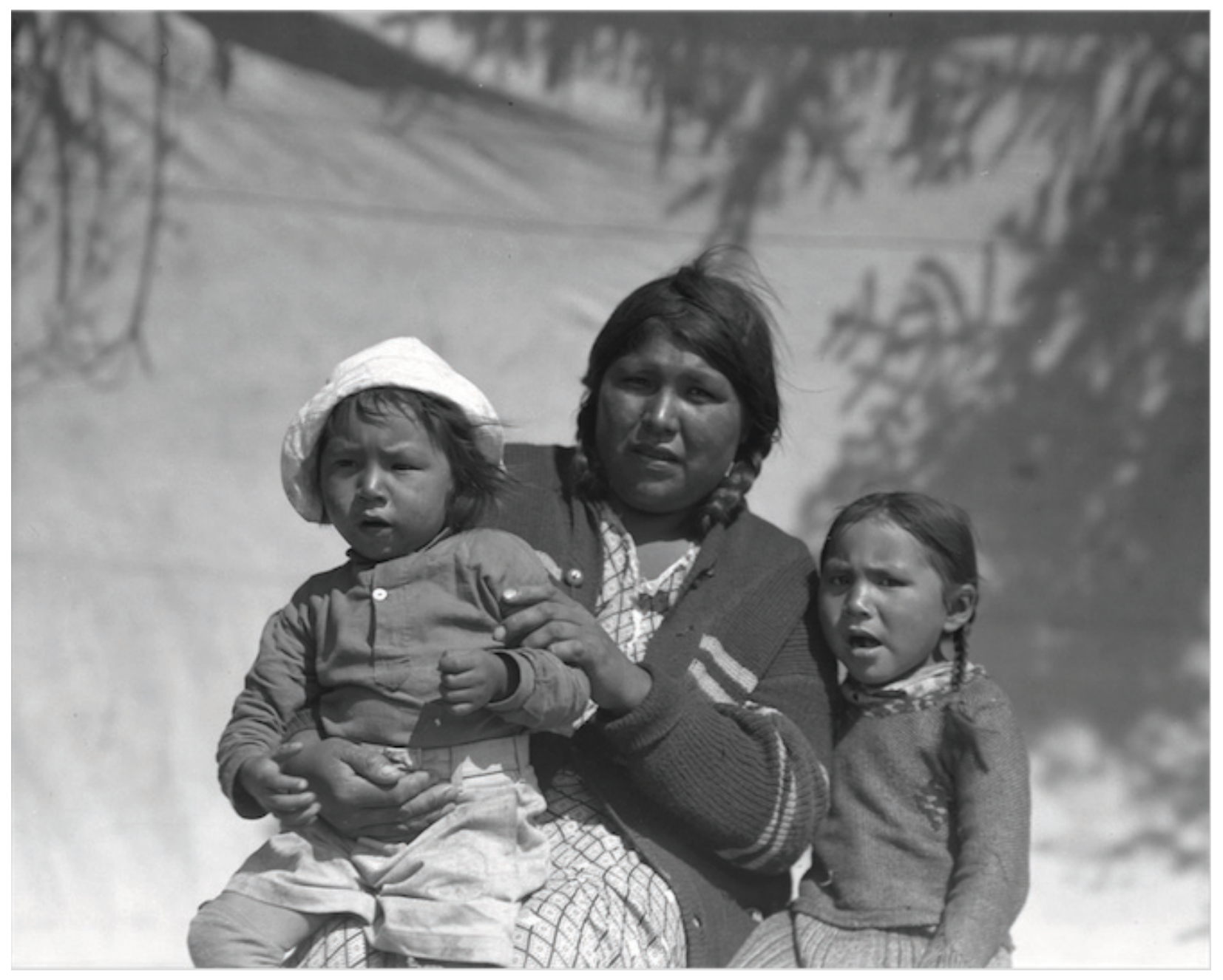

Figure 2.1 Byron Harmon, "Lucy Ear," [ca.1920-1930], V263/NA-3218, Byron Harmon Fonds, Archives \& Library, Whyte Museum of the Canadian Rockies. 


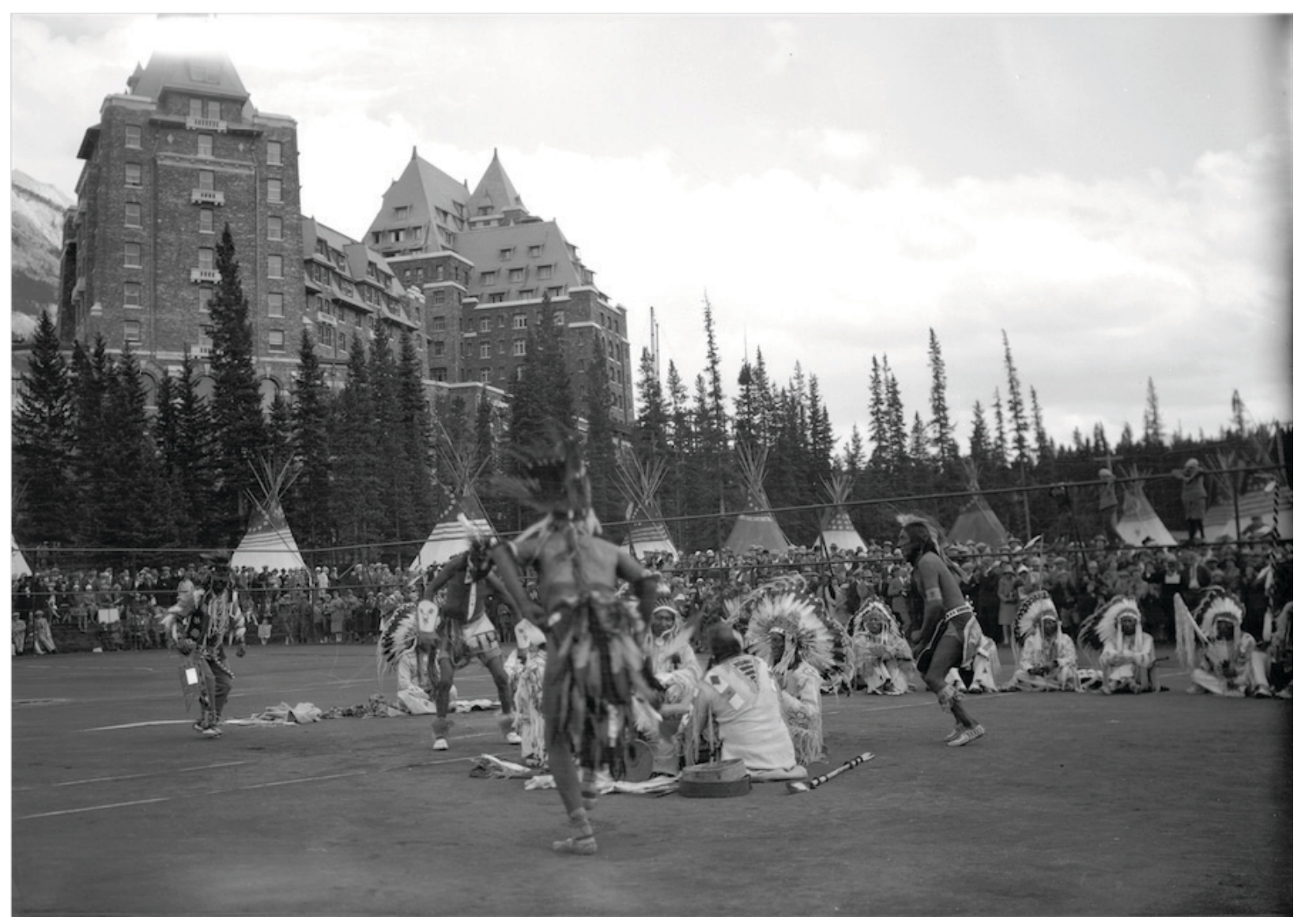

Figure 2.2 Byron Harmon, "Indian Days, at Banff Springs Hotel," [ca.1930], V263/NA3353, Byron Harmon Fonds, Archives \& Library, Whyte Museum of the Canadian Rockies. 


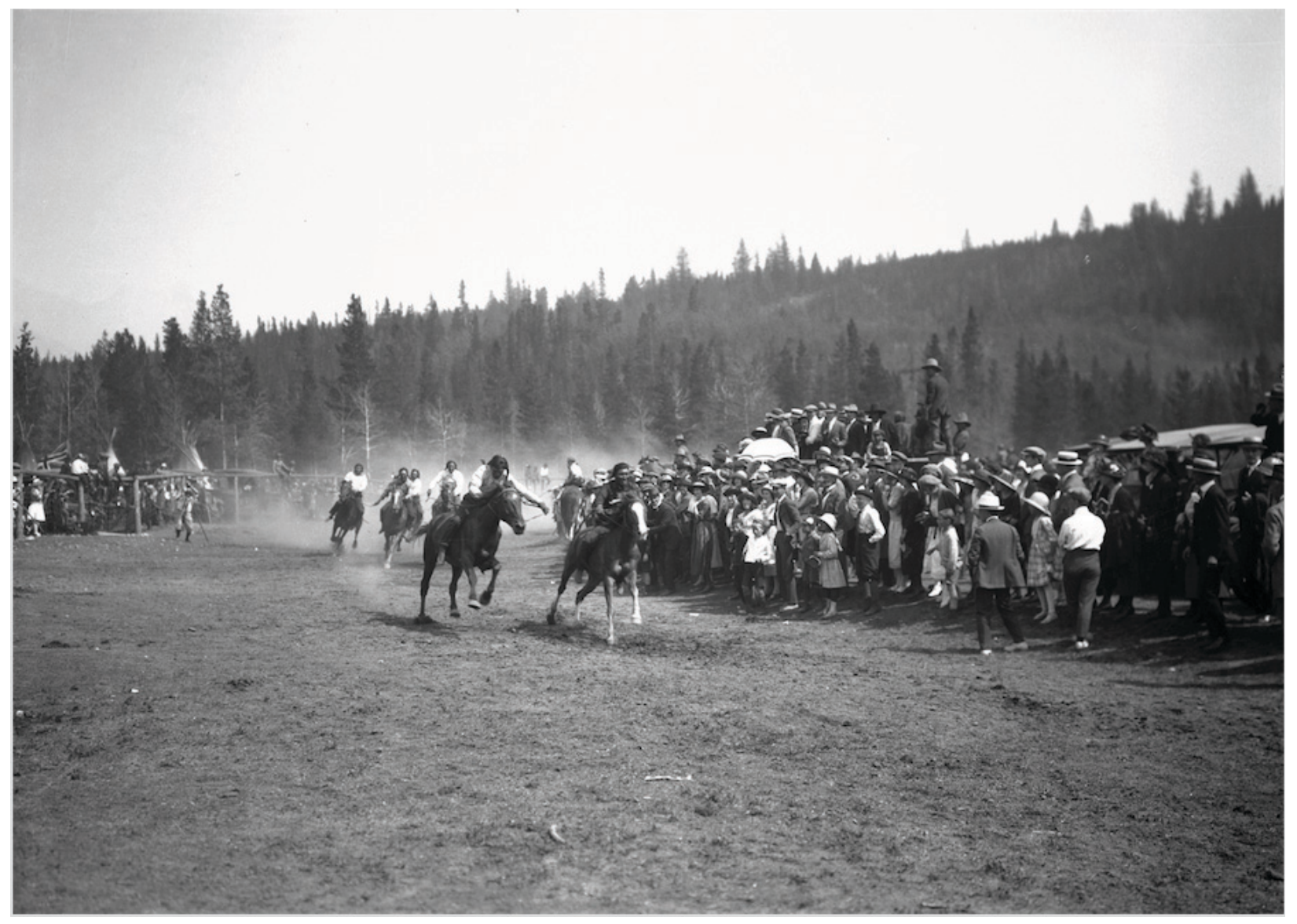

Figure 2.3 Byron Harmon, "Banff Indian Days race,” [ca.1925], V263/NA-3324, Byron Harmon Fonds, Archives \& Library, Whyte Museum of the Canadian Rockies. 


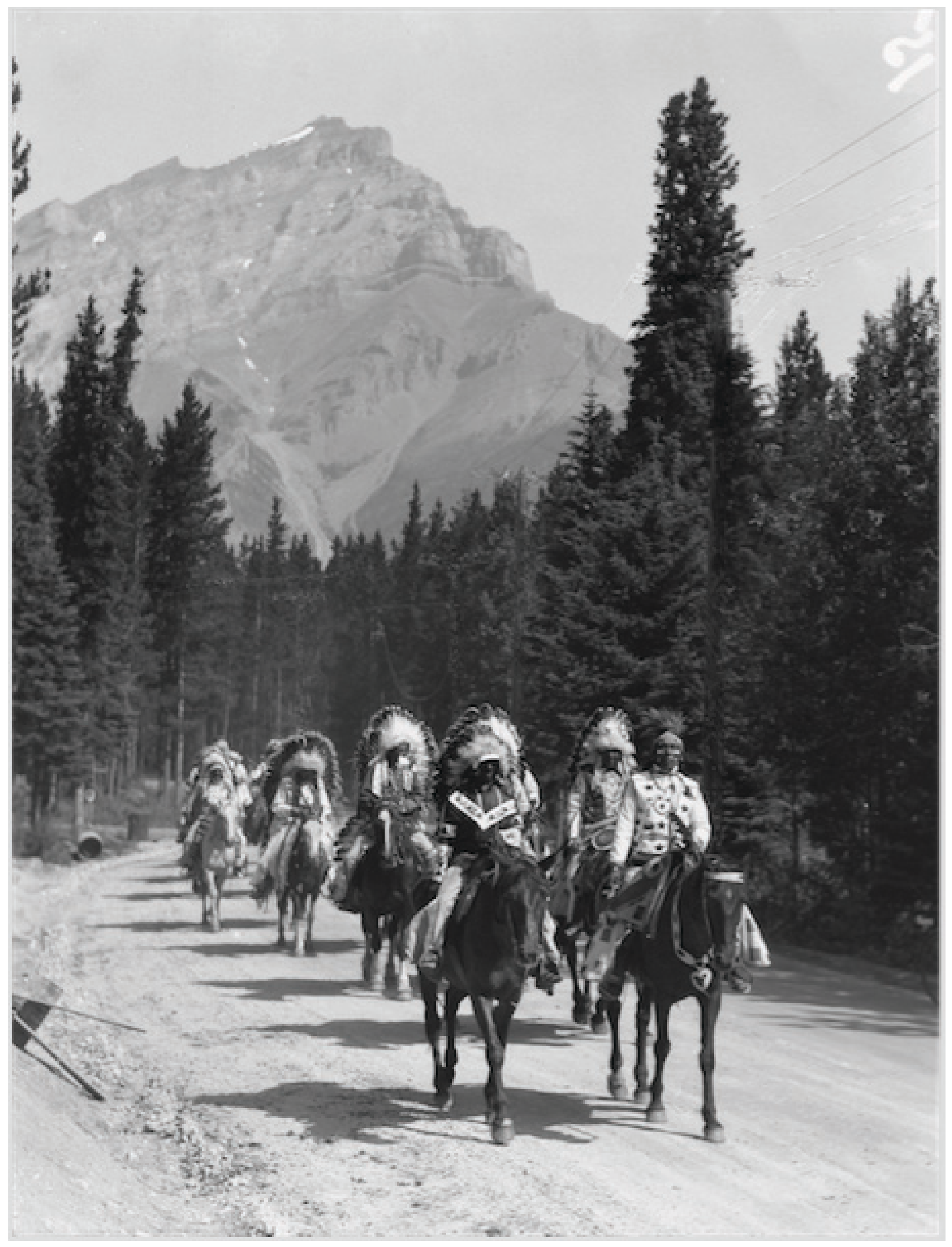

Figure 2.4 Byron Harmon, "Banff Indian Days parade,” [ca.1910], V263/NA-3362, Byron Harmon Fonds, Archives \& Library, Whyte Museum of the Canadian Rockies. 


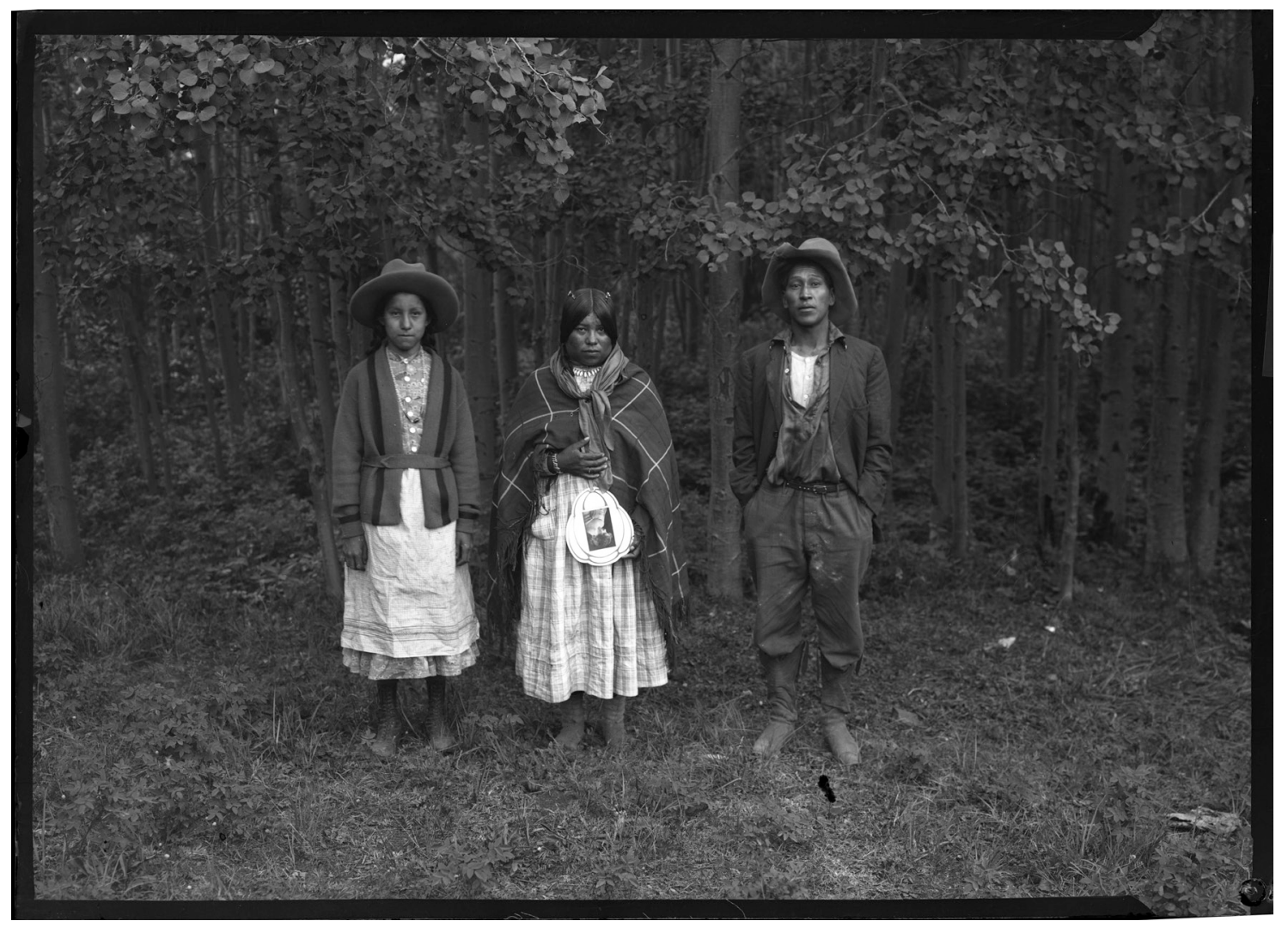

Figure 3.1 Byron Harmon, "E-22, Banff Indian Days" [ca.1925], V263/NA-3345. "Stoney First Nation, Alma Wildman (sister of Burt Wildman), Elizabeth or Lily (sister of Jimmy Wildman) (future wife of Lazarus Wesley), Paul Poucette (Pa-to-gen)(Pa is head, To is blue, Gen is an endearment)," Byron Harmon Fonds, Archives \& Library, Whyte Museum of the Canadian Rockies. 


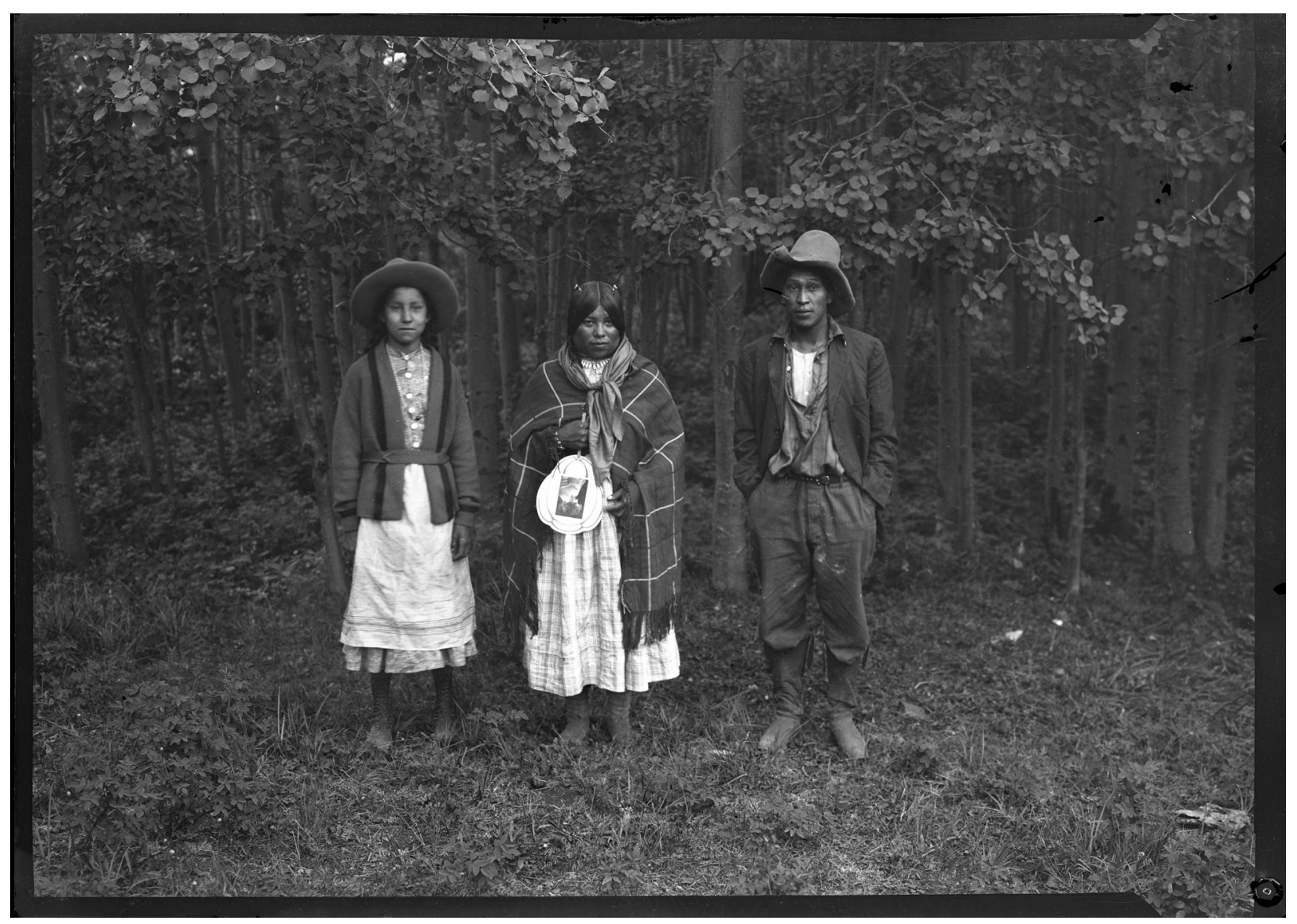

Figure 3.2 Byron Harmon, "Banff Indian Days," [ca.1925]. V263/NA-3344. "Alma Wildman (sister of Burt Wildman), Elizabeth or Lily (sister of Jimmy Wildman) (future wife of Lazarus Wesley), Paul Poucette (Pa-to-gen)(Pa is head, To is blue, Gen is an endearment)." Byron Harmon Fonds, Archives \& Library, Whyte Museum of the Canadian Rockies. 


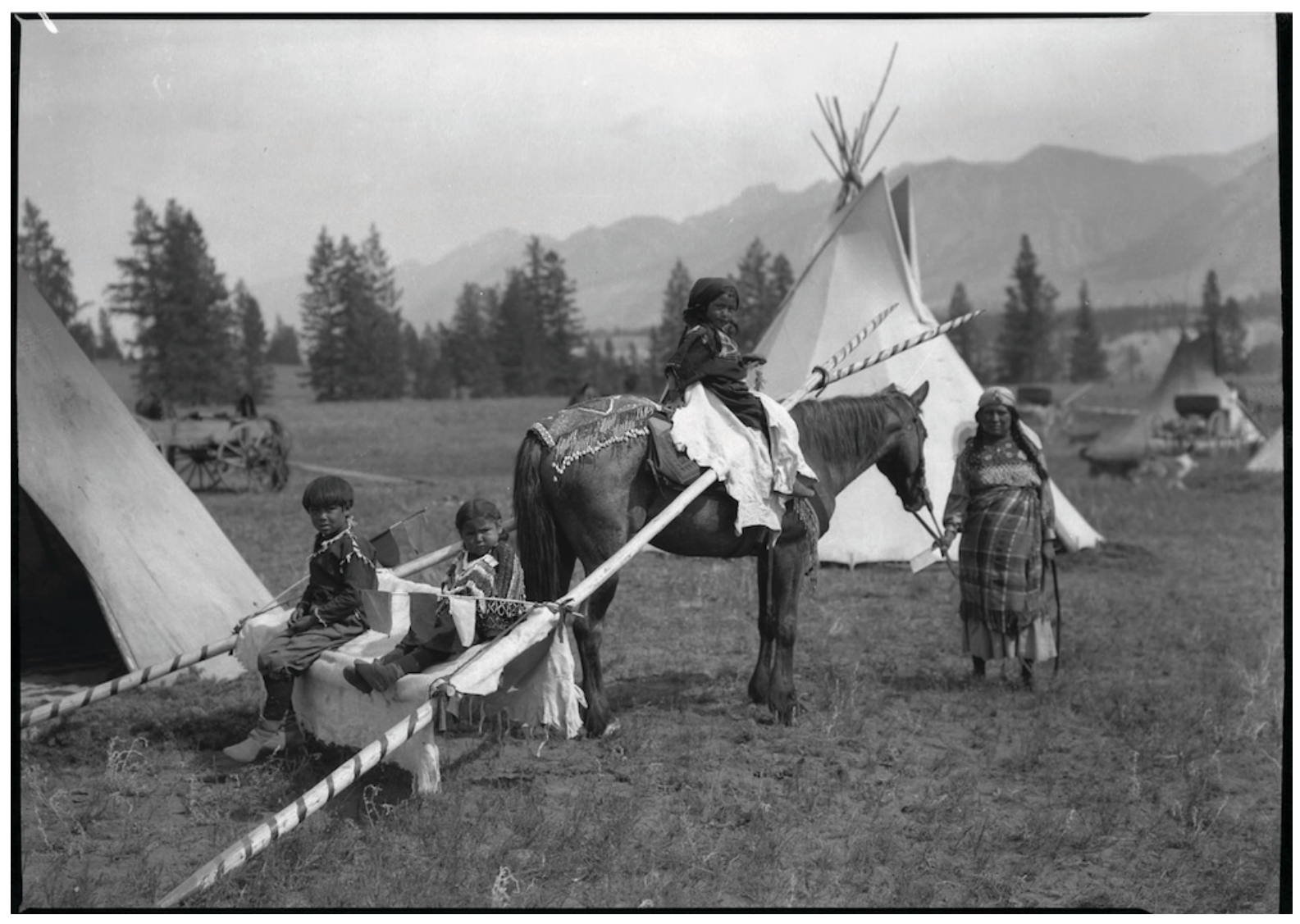

Figure 3.3 "Indian Travois" [ca.1920-1930], V263/NA-3140, Byron Harmon Fonds, Archives \& Library, Whyte Museum of the Canadian Rockies. 


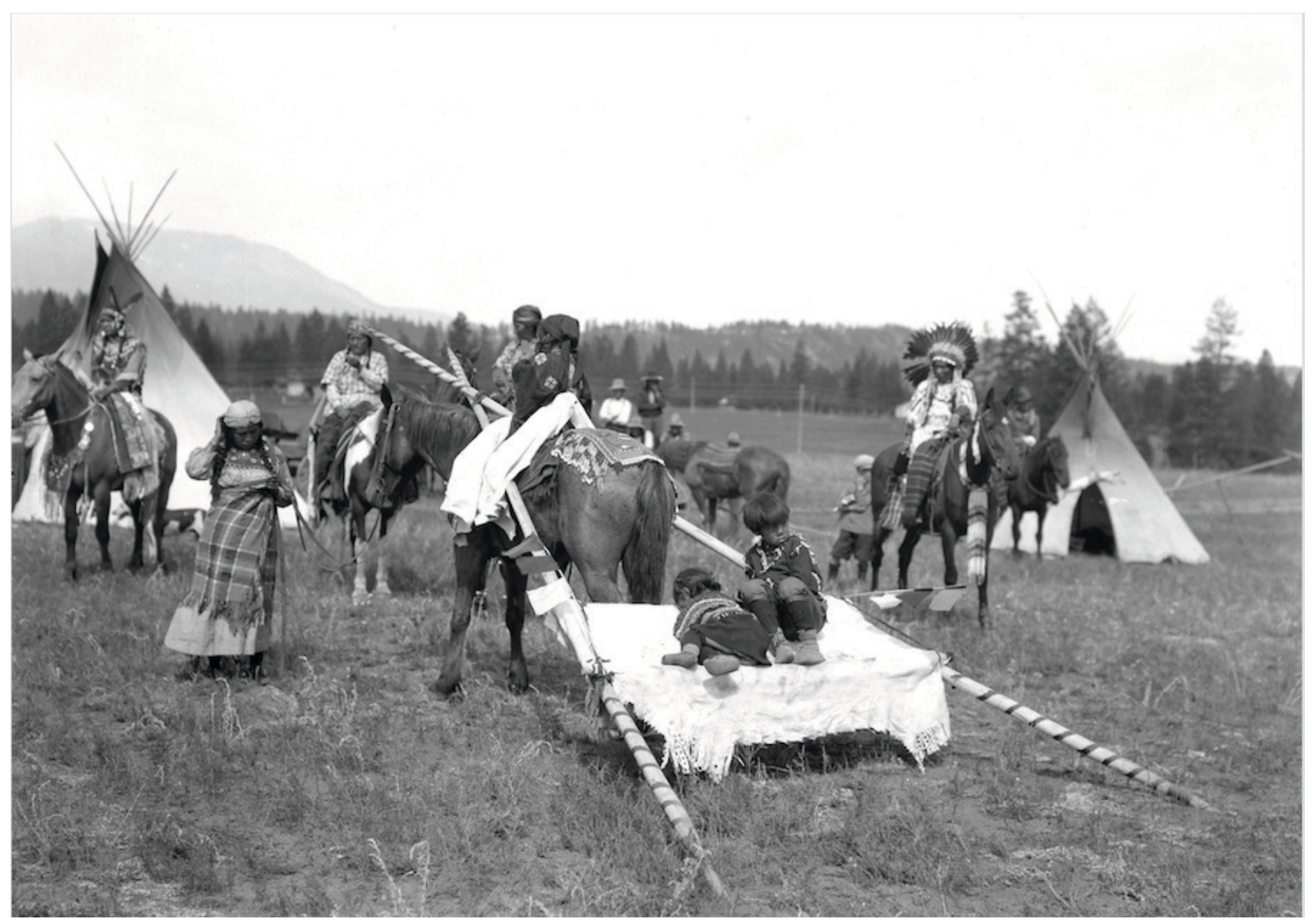

Figure 3.4 "Indian Travois" [ca.1920-1930], V263/NA-3139, Byron Harmon Fonds, Archives \& Library, Whyte Museum of the Canadian Rockies. 


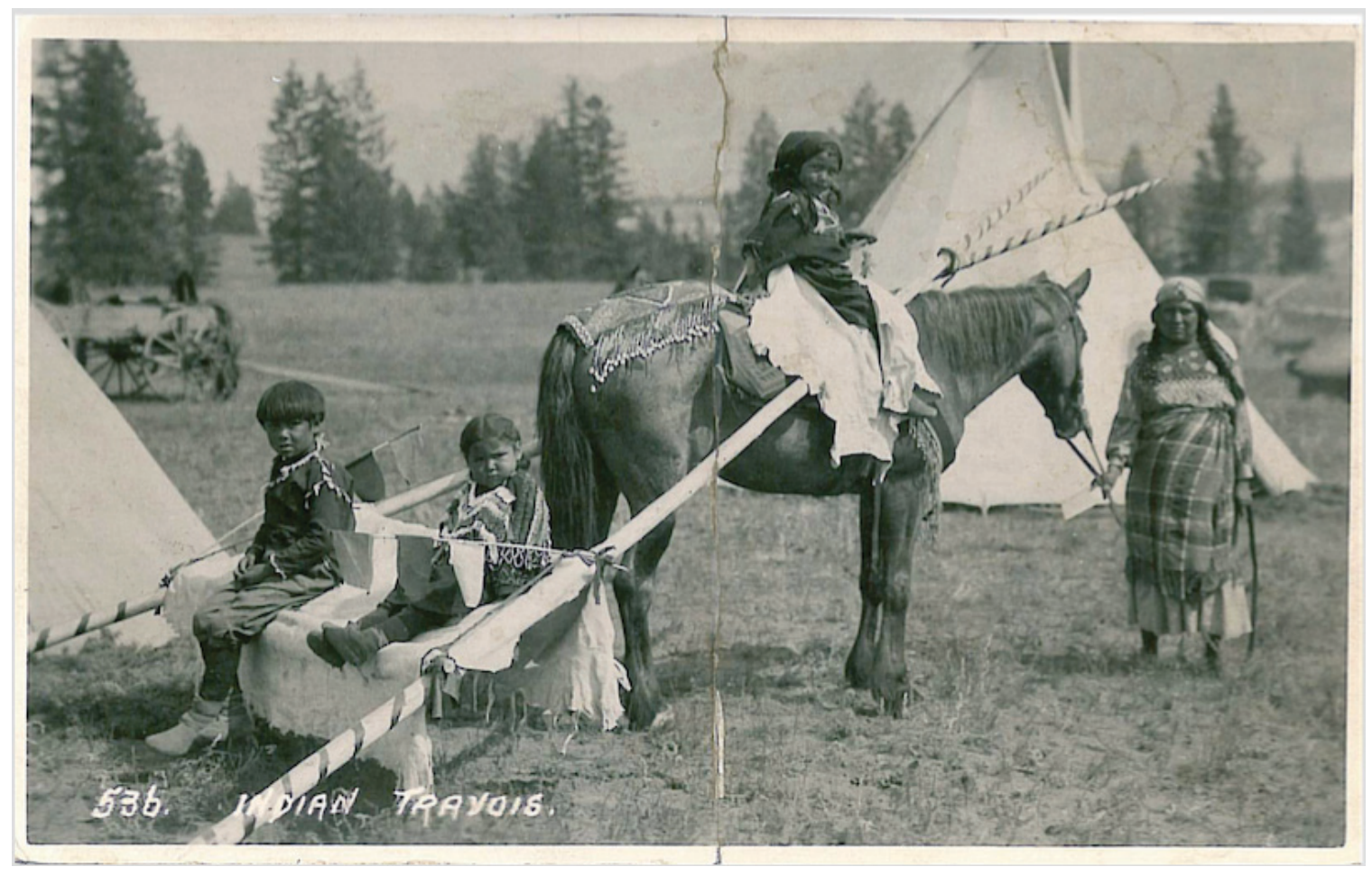

Figure 3.5 Byron Harmon, "Indian Travois," V263/PG-bw-536, Byron Harmon Fonds, Archives \& Library, Whyte Museum of the Canadian Rockies.

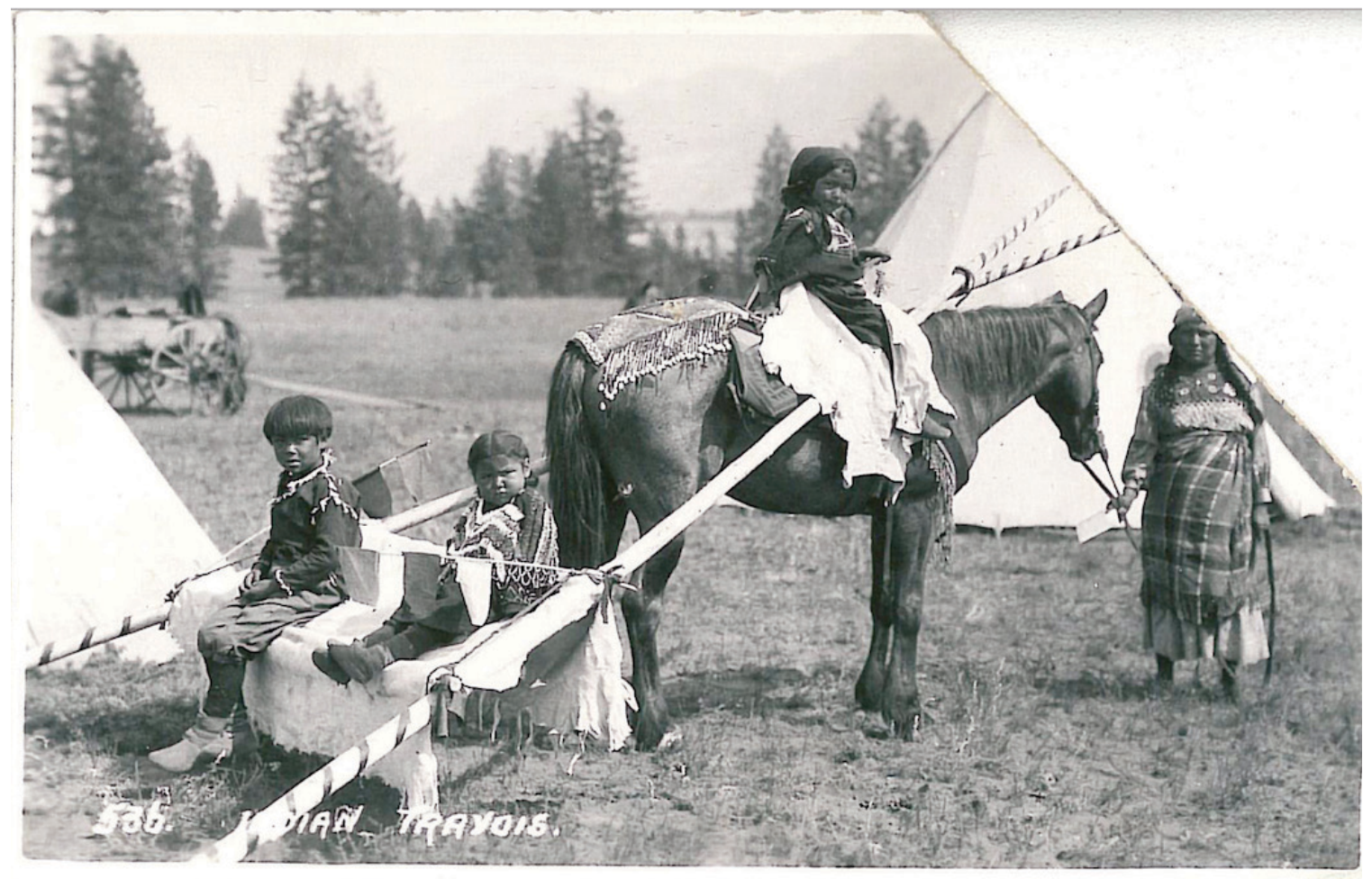

Figure 3.6 Byron Harmon, "Indian Travois," V263/PG-bw-536-1, Byron Harmon Fonds, Archives \& Library, Whyte Museum of the Canadian Rockies. 


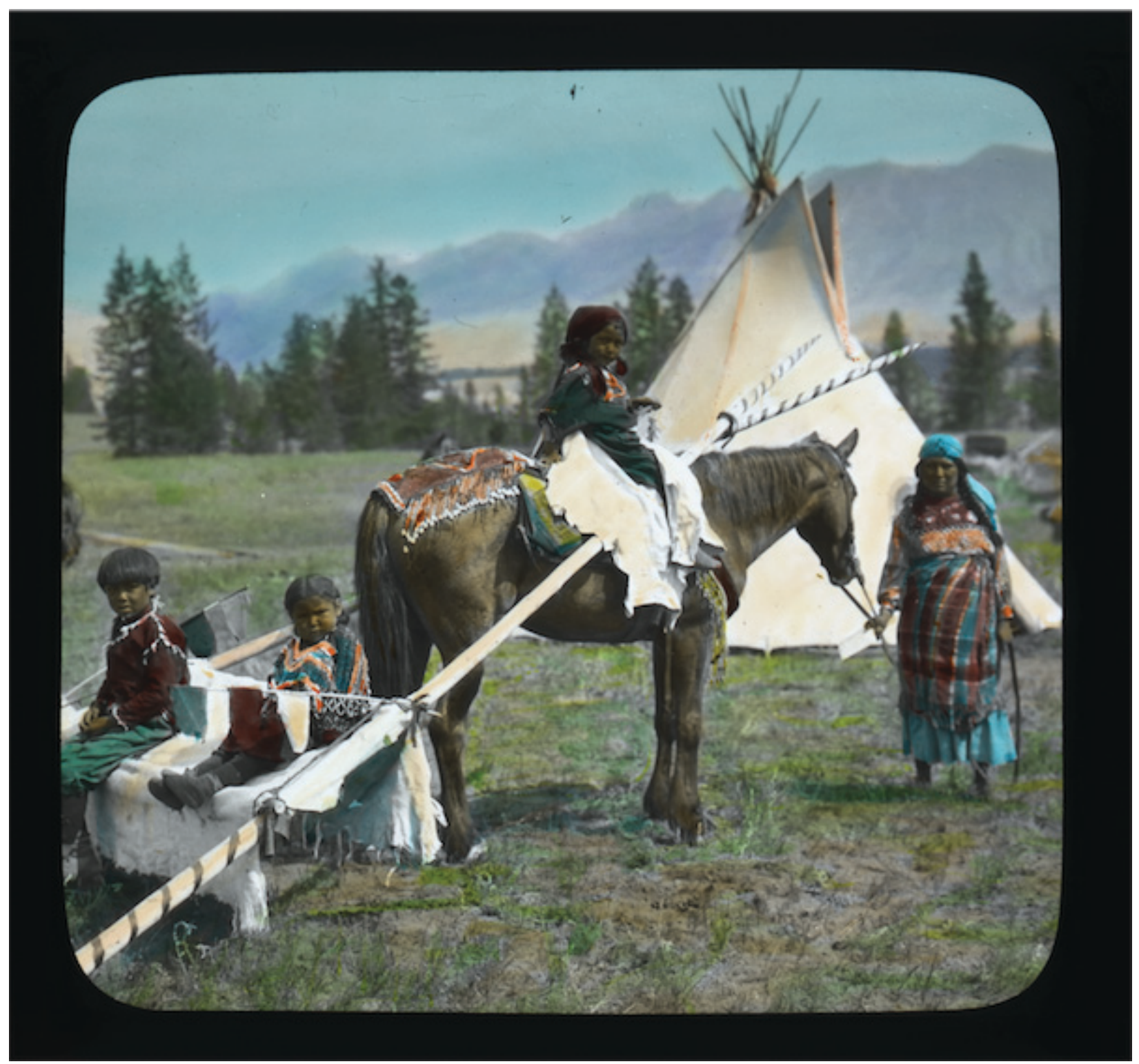

Figure 3.7 Moore Family Fonds, [Unidentified woman and children with travois], 1899 1927, V439-ps-321 Moore Family Fonds, Archives \& Library, Whyte Museum of the Canadian Rockies. 


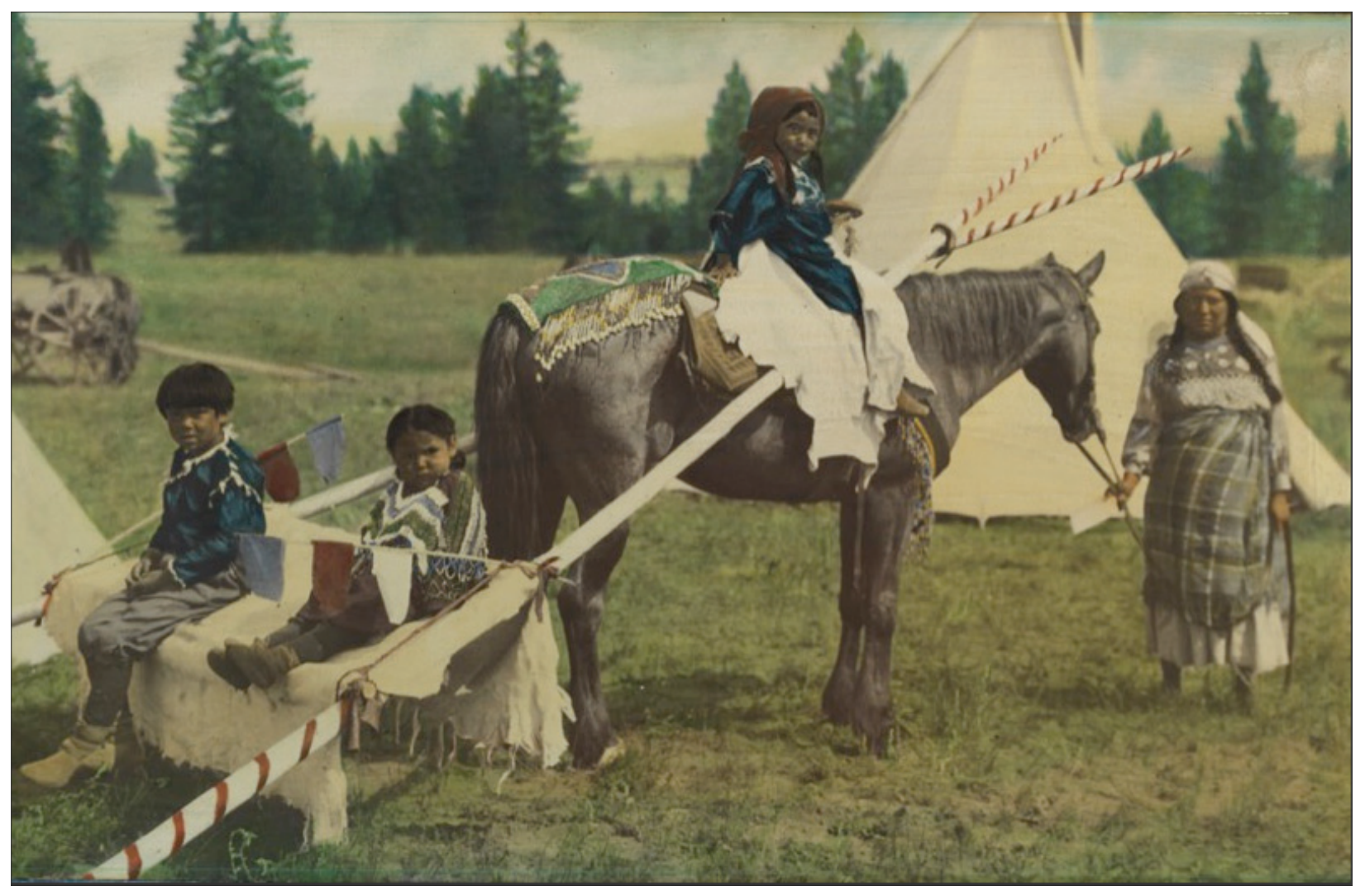

Figure 3.8 Byron Harmon, S06 Stoney Family and Trava (travois) Stoney Limited Edition Portfolio. http://www.byronharmonphotos.com/editions/stoneyLTD/index.html. Last modified 2013. Used with permission by Carole Harmon. 


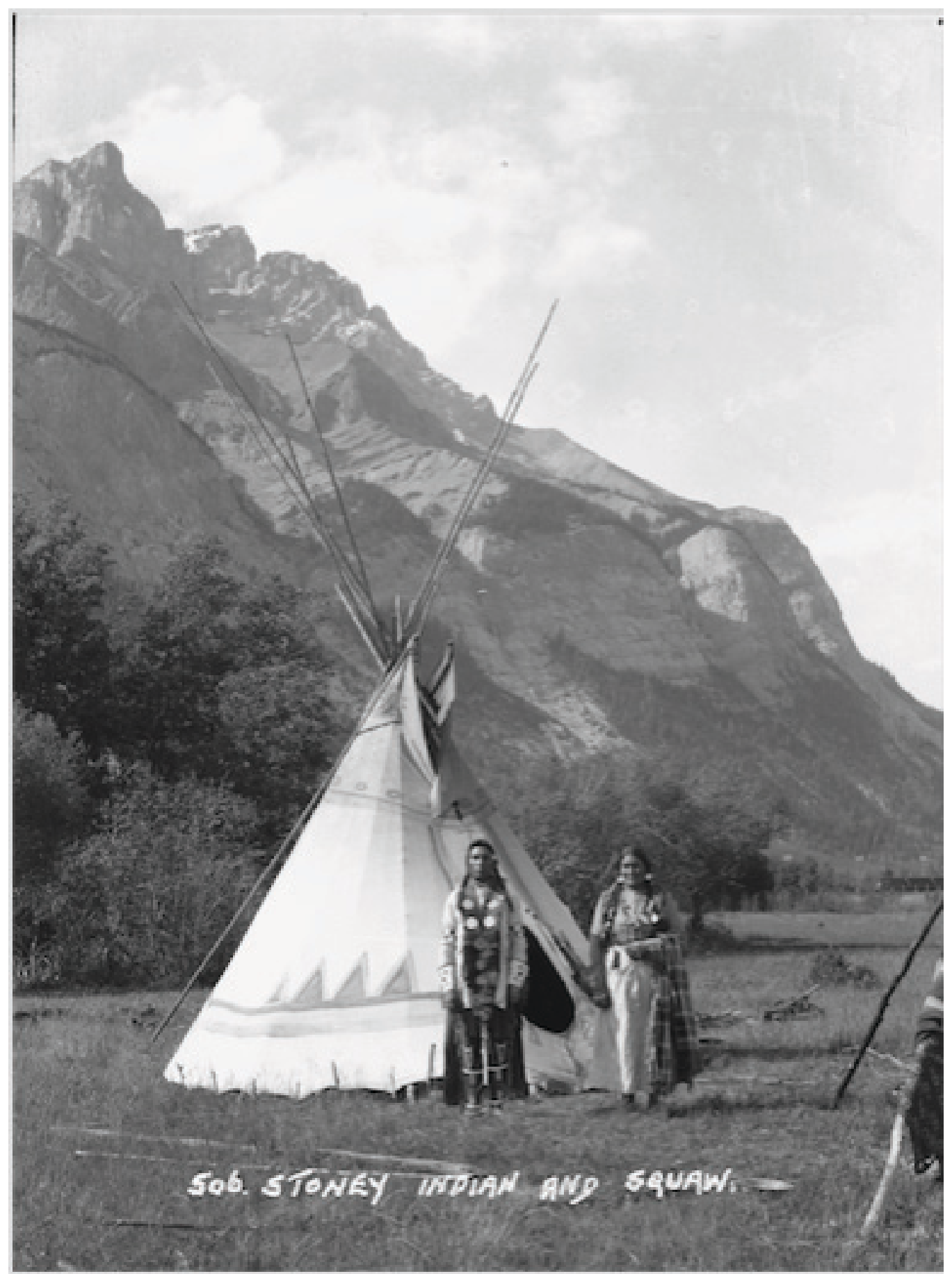

Figure 3.9 Byron Harmon, "506.Stoney Indian and Squaw” [ca.1915-1925], V263/NA3258, Identified as Mr. and Mrs. Job Stephens through the Recognizing Relations Project. Byron Harmon Fonds, Archives \& Library, Whyte Museum of the Canadian Rockies. 


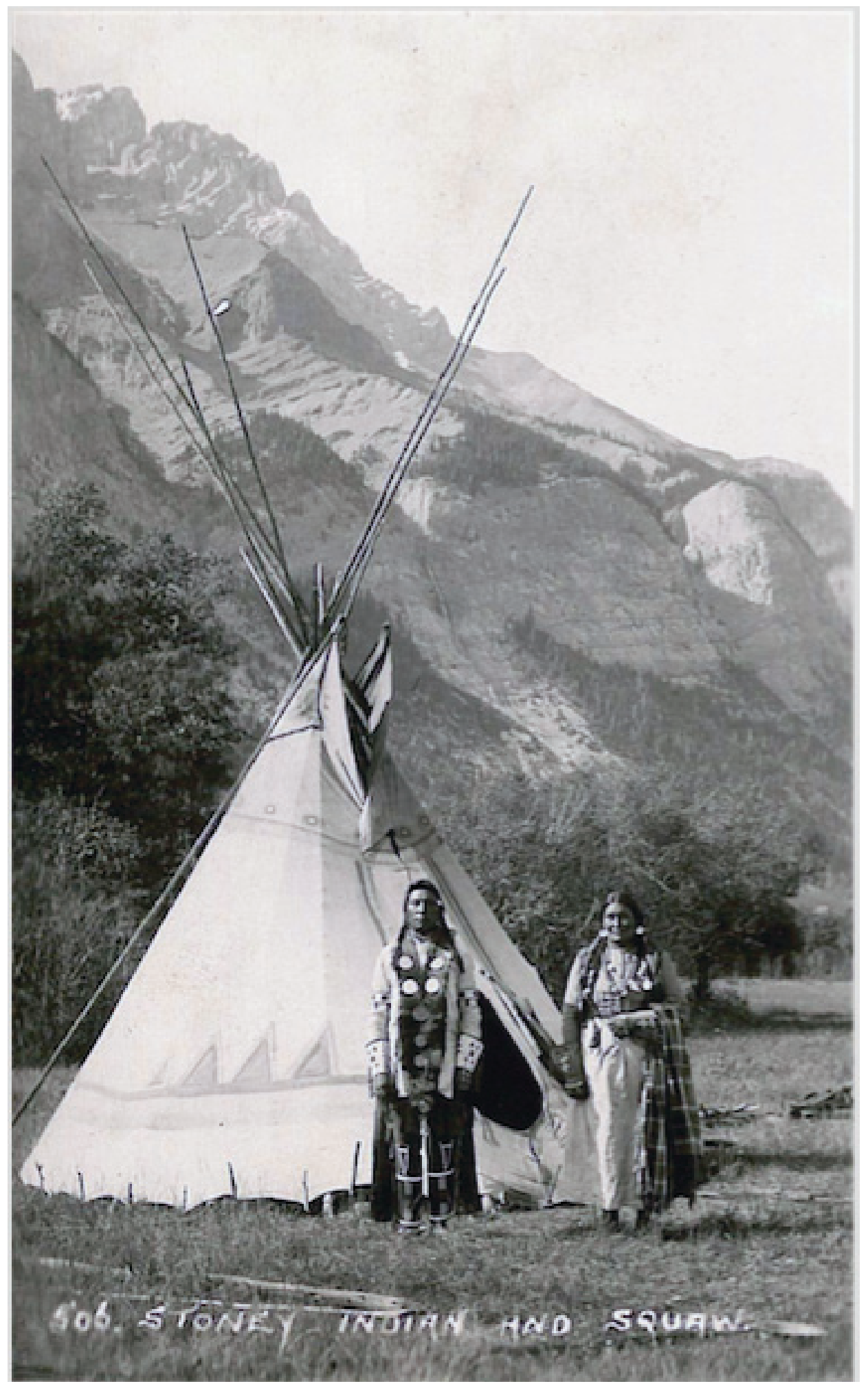

Figure 3.10 Byron Harmon, "Stoney Indian and Squaw," V263/PG-bw-506, Byron Harmon Fonds, Archives \& Library, Whyte Museum of the Canadian Rockies. 


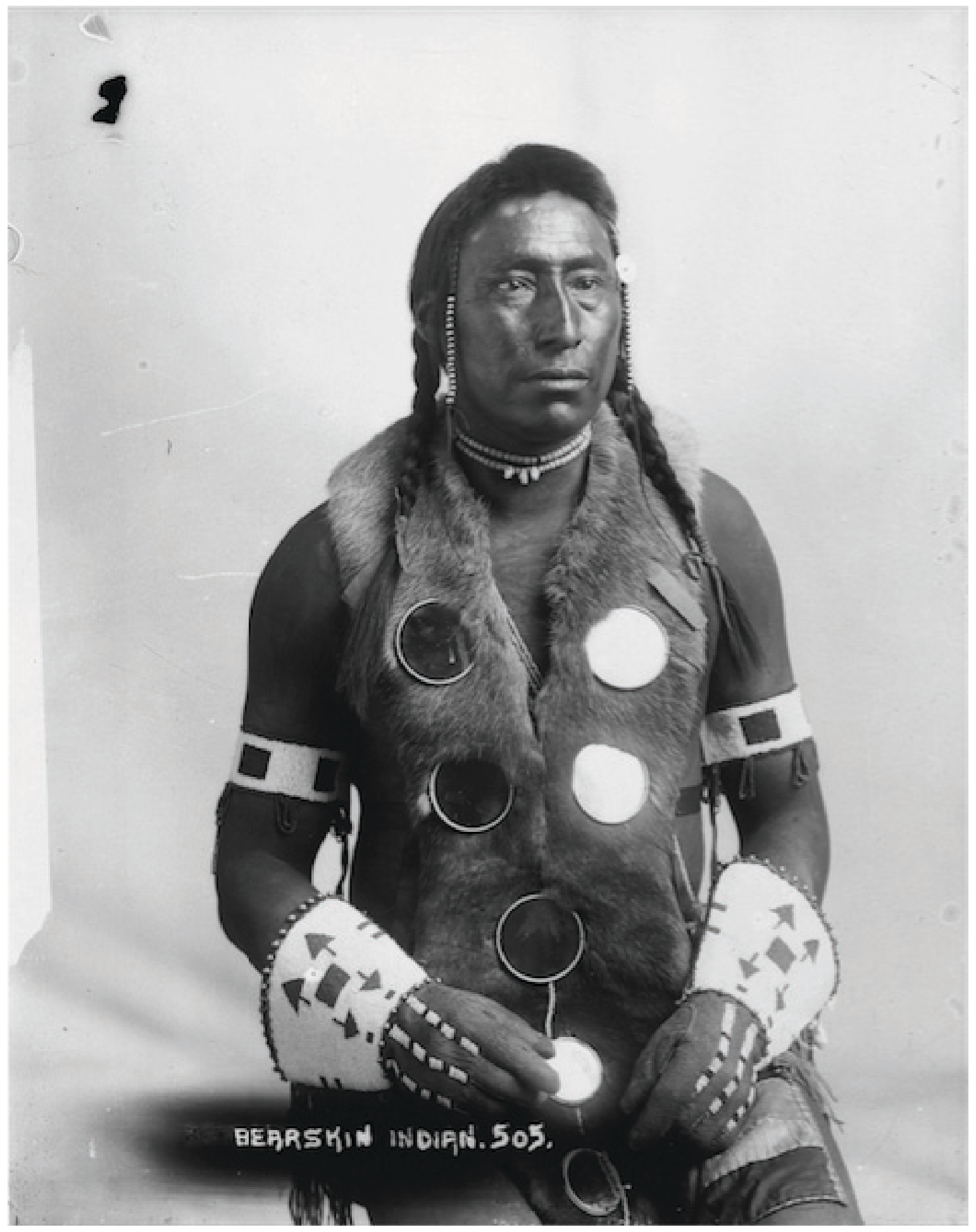

Figure 3.11 Byron Harmon, “505. Bearskin Indian,” Identified as Joe Stevens, V263/NA3119, Byron Harmon Fonds, Archives \& Library, Whyte Museum of the Canadian Rockies. 


\section{Bibliography}

\section{Primary Sources}

Byron Harmon Fonds, V263, Archives \& Library, Whyte Museum of the Canadian Rockies.

Carole Harmon. Interview with author. March 2016.

Dagny Dubois. Email message to author. April 20, 2016.

Elliot Barnes Fonds, V48, Archives \& Library, Whyte Museum of the Canadian Rockies.

Mary Schäffer Fonds M79/V527, Archives \& Library, Whyte Museum of the Canadian Rockies.

Noble Family Fonds V360, Archives \& Library, Whyte Museum of the Canadian Rockies.

\section{Secondary Sources}

Applegate Krouse, Susan. "Photographing the Vanishing Race," Visual Anthropology 3 (1990): 213-233.

Barnes, John. "Classification of Magic Lantern Slides for Cataloguing and Documentation." Magic Images: The Art of Hand-Painted and Photographic Lantern Slides. Edited by Dennis Crompton, David Henry, and Stephen Hebert. London: Magic Lantern Society of London, 1990.

Barthes, Roland. Image, Music, Text. New York: Hill and Wang, 1977.

Benson, Richard. The Printed Picture. New York: Museum of Modern Art, 2008.

Binnema, Theodore (Ted), and Melanie Niemi. 2006. "'Let the Line Be Drawn Now': Wilderness, Conservation, and the Exclusion of Aboriginal People from Banff National Park in Canada". Environmental History 11 (4). Forest History Society, Forest History Society and The American Society for Environmental History, American Society for Environmental History, Oxford University Press: 724-50. http://www.jstor.org.proxy.library.carleton.ca/stable/3985800. Accessed October $25,2015$.

Birrell, A.J. Into the Silent Land: Survey Photography in the Canadian West, 1858-1900 A Public Archives of Canada Travelling Exhibition. Ottawa: Information Canada, 1975.

Blackadar, R. G. On the Frontier: Photographs by the Geological Survey of Canada. Ottawa: Geological Survey Canada, 1982.

Bradford, Tolly. “A Useful Instituion: William Twin, 'Indianness' and Banff National Park, c. 1860-1940.” Native Studies Review 16 (2005): 77-98. 
Brown, Alison K. and Laura L. Peers. Pictures Bring us Messages = Sinaakssiiksi Aohtsimaahpihkookiyaawa: Photographs and Histories from the Kainai Nation. Toronto: University of Toronto Press, 2006.

Byron Harmon Photos "Stoney Limited Edition Portfolio," (http://www.byronharmonphotos.com/editions/stoneyLTD/index.html). Last Modified 2013.

Carter, Sarah. Capturing Women: The Manipulation of Cultural Imagery in Canada's Prairie West. Montreal: McGill-Queen's University Press, 1997.

Clapperton, Jonathan. "Naturalizing Race Relations: Conservation, Colonialism, and Spectacle at the Banff Indian Days." The Canadian Historical Review, 94 (2013): 349-379.

Cavell, Edward. Journey To The Far West. Toronto: James Lorimer \& Company, 1979.

Daschuk, James. Clearing the Plains: Disease, Politics of Starvation, and Loss of Aboriginal Life. Regina, Saskatchewan: University of Regina Press, 2013.

Decter, Leah and Carla Taunton, "Addressing the Settler Problem: Strategies of Settler Responsibility and Decolonization,” Fuse Magazine 36 (2013): 32-39.

Dempsey, Hugh A. Indians of the Mountain Parks. Calgary: Fifth House Ltd. 1998.

Devereaux, Cecily. "Finding Indian Maidens on eBay: Tales of the Alternative Archive (and More Tales of White Commodity Culture)." In Basements and Attics, Closets and Cyberspace: Explorations in Canadian Women's Archives, edited by Linda M. Morra and Jessica Schagerl, 29-45. Waterloo: Wilfred Laurier University Press, 2012.

Edwards, Elizabeth. "Photographs and The Sound of History," Visual Anthropology Review 21 (2006): 27-46.

_ "Material Beings: Objecthood and Ethnographic Photographs." Visual Studies 17 (2002): 67-75.

— . "Objects of Affect: Photography Beyond the Photographic Image," Review of Anthropology 41 (2012): 221-234.

—. "Photography and the Material Performances of the Past." History and Theory 48 (2009): 130-150.

- "Photographs, Mounts, and the Tactile Archive." Interdisciplinary Studies in the Long Nineteenth Century 19 (2014): 1-9. 
- The Resonance of Anthropology. In Native Nations: Journeys in American Photography. Edited by Jane Alison. London: Barbican Art Gallery, 1998.

Edwards, Elizabeth and Janice Hart. "Mixed Box: The Cultural Biography of a box of 'ethnographic' photographs." In Photographs Object Histories, edited by Elizabeth Edwards and Janice Hart, 48-64. New York: Rutledge, 2004.

Farrell Racette, Sherry. "Returning Fire, pointing the Canon: Aboriginal Photography as Resistance." In The Cultural Work of Photography in Canada. Edited by Andrea Kunard and Carol Payne, 70-90. Montreal \& Kingston: Queens University Press, 2011.

Francis, Margot. Creative Subversions: Whiteness, Indigeneity, and the National Imaginary. Vancouver: UBC Press, 2011.

Friedman, Susan Stanford. "Periodizing Modernism: Postcolonial Modernities and the Space/Time Borders of Modernist Studies." Modernism/modernity 12 (2006): 425-443.

Gidley, Mick ed. Edward S. Curtis and the North American Indian Project in the Field. Lincoln: University of Nebraska Press, 2003.

- Edward S. Curtis and the North American Indian Project in the Field. Lincoln: University of Nebraska Press, 2003.

Glass, Aaron "A Cannibal in the Archive: Performance, Materiality, and (In)Visibility in Unpublished Edward Curtis Photographs of the Kwakwaka'wakw Hamat'sa," Visual Anthropology Review 25 (2009): 128-149.

Greenhill, Ralph. Early Photography in Canada. Toronto: Oxford University Press, 1965.

Hall, E. Early Canada: A Collection of Historical Photographs by Officers of the Geographical Survey of Canada. Ottawa: Canada Department of Energy, Mines and Resources, 1967.

Harmon, Byron. Great days in the Rockies: The Photographs of Byron Harmon, 19061934. Edited by Carole Harmon and the Peter and Catherine Whyte Foundation. Toronto: Oxford University Press, 1978.

Harmon, Byron. Byron Harmon, Mountain Photographer. Edited by Carole Harmon. Banff: Altitude Publishing, 1992.

Harmon, Carole. "Stoney Limited Edition Portfolio," http://www.byronharmonphotos.com/editions/stoneyLTD/index.html. Last Modified 2013. 
Hart, Avril, and Emma Taylor. Fans. London: V\&A Publications, 1998.

Hart, E.J. The Selling of Canada: The CPR and the Beginnings of Canadian Tourism. Banff: Altitude Publishing, 1983.

Hepworth, Thomas Craddock. The Book of Lantern. New York: Arno Press, 1978.

Hildebrandt, Walter, Dorothy First Rider, and Sarah Carter. The True Spirit and Original Intent of Treaty 7. Montreal: McGill-Queen's University Press, 1996.

"Historical Lens.” The Columbia Valley Pioneer, August 28, 2015.

Hoelscher, Steven D. Picturing Indians: Photographic Encounters and Tourist Fantasies in H.H. Bennett's Wisconsin Dells. Madison, Wisconsin: University of Wisconsin Press, 2008.

Hugh Dempsey, Indians of the Rocky Mountain Parks, (Calgary: Fifth House Publishers, 1998).

Hungry Wolf, Adolf and Beverly. Indian Tribes of the Northern Rockies. Skookumchuck: Good Medicine Books, 1989.

Huyda, Richard J. Camera in the Interior: 1858. Toronto: The Couch House Press, 1988.

Indigenous and Northern Affairs Canada. The Numbered Treaties (1871-1920).

Indigenous Affairs and Northern Affairs Canada http://www.aadncaandc.gc.ca/eng/1360948213124/1360948312708

Ketchum, Shanna. "Native Cosmopolitan Modernism(s): A Re-articulation of Presences through Time and Space." Third Text 19 (2005): 357-364.

Kunard, Andrea. "Relationships of Photography and Text in the Colonization of the Canadian West: The 1858 Assiniboine and Saskatchewan Exploring Expedition." International Journal of Canadian Studies 26 (2002): 77-100.

Kopytoff, Igor. "The Cultural Biography of Things: Commoditization As Process," in The Social Life of Things: Commodities in Cultural Process, ed. Arjun Appadurai (Cambridge: Cambridge University Press, 1976), 67.

Lippard, Lucy R. "Introduction." In Partial Recall, 11-45. New York: New Press, 1992.

Lonetree, Amy. "Visual Native Survivance: Encounters with My Ho-Chunk Ancestors in the Family Photographs of Charles Van Schaick." In People of the Big Voice: Photographs of Ho-Chunk Families by Charles Van Schaick, 1879-1942. Edited by Tom Jones, Michael Schmudlach, Matthew Daniel Mason, Amy Lonetree, \& George A. Greendeer. Madison, Wisconsin: Wisconsin Historical Society Press, 2011. 
Lux, M. K. Medicine that walks: Disease, medicine, and Canadian plains Native people, 1880-1940. Toronto: University of Toronto Press, 2001.

Luxton, Eleanor G. Banff: Canada's First National Park. Banff: Summerthought, 2008.

Lyman. Christopher M. The Vanishing Race and Other Illusions: Photographs of Indians by Edward S. Curtis. New York: Pantheon in Association with the Smithsonian Institution, 1982.

Lydon, Joan. "Return: The Photographic Archive and Technologies of Indigenous Memory." Photographies 3 (2010): 173-187.

MacEachern, Alan. "M.B. Williams and the Early Years of Parks Canada." In A Century of Parks Canada 1911-2011. Edited by Claire Campbell, 21-52. Calgary: University of Calgary Press, 2011.

Mason, Courtney Wade. Spirits of the Rockies: Reasserting an Indigenous Presence in Banff National Park. Toronto: University of Toronto Press, 2014.

—. "The Construction of Banff as a 'Natural' Environment: Sporting Festivals, Tourism, and Representations of Aboriginal Peoples." Indigenous Sport, 35, (2008): 221-239.

Maxwell, Anne. "Shifting Focus: Photographic Representations of Native Americans and African-Americans." In Colonial Photography and Exhibitions. London and New York: Leicester University Press: 1999.

"Members of Stoney Nakoda." Windspeaker, October 9 2012. Accessed April 162015. https://proxy.library.carleton.ca/login?url=http://go.galegroup.com.proxy.library.c arleton.ca/ps/i.do?id=GALE\%7CA307527038\&sid=summon $\& v=2.1 \& u=$ ocul_car leton\&it $=\mathrm{r} \& \mathrm{p}=\mathrm{AONE} \& \mathrm{sw}=\mathrm{w} \& \mathrm{asid}=9431 \mathrm{dd} 3 \mathrm{c} 41 \mathrm{e} 5382 \mathrm{eec} 46215 \mathrm{e} 87687 \mathrm{c} 24$

Mercer, Kobena. "Introduction.” In Cosmopolitan Modernisms. Edited by Kobena Mercer, 7-23. Cambridge MA.: MIT Press, 2005.

Milloy, John Sheridan. Indian Act Colonialism: A Century of Dishonour, 1869-1969.

West Vancouver, B.C.: National Centre for First Nations Governance, 2008.

Opp, James. "The Colonial Legacy of the Digital Archive: The Arnold Lupson Photographic Collection." Archivaria, 65 (2008): 3-19.

“Origin,” http://www.rockymountainnakoda.com/, last modified 2015.

Payne, Carol. "Through a Canadian Lens: Discourses of Nationalism and Aboriginal Representation in Governmental Photography." In Canadian Cultural Poesis: An Anthology, Edited by Sheila Petty, Annie Gérin, and Garry Sherbert. 421-442. Waterloo: Wilfrid Laurier University Press, 2006). 
Payne, Carol and Andrea Kunard "Writing Photography in Canada." In The Cultural Work of Photography in Canada, edited by Andrea Kunard and Carol Payne. Montreal \& Kingston: Queens University Press, 2011.

Philips, Ruth B. "Making Sense Out/Of the Visual: Aboriginal Representations in Nineteenth-Century Canada." Art History 27 (2004): 593-615.

Pinney, Christopher. Photography and Anthropology. London: Reaktion Books, 2011.

Perry, Adele. On the Edge of Empire: Gender, Race, and the Making of British Columbia, 1849-1871. Toronto: University of Toronto Press, 2001.

Poole, Deborah. "An Excess of Description: Ethnography, Race, and Visual Technologies," Review of Anthropology, 34 (2005), 159-179.

Pratt, Mary Louise. Imperial Eyes: Travel Writing and Transculturation. London: Routledge, 1992.

Pratt, Stephanie. "Restating Indigenous Presence in Eastern Dakota and Ho Chunk (Winnebago) Portraits of the 1830s-1860s." In Indigenous Bodies: Reviewing, Relocating, Reclaiming, edited by Jaqueline Fear-Segal and Rebecca Tillet, 17-28. Albany: State University of New York Press, 2013.

Robinson, Bart. "A Biographical Portrait of Byron Harmon.” In Great days in the Rockies: The Photographs of Byron Harmon, 1906-1934, edited by Carole Harmon and the Peter Whyte Foundation, 7-20. Toronto: Oxford University Press, 1978.

Regan, Paulette. Unsettling the Settler Within. Vancouver: UBC Press, 2010.

Rutkair, Jennifer. "Forward," in A Hunter of Peace, second edition, Mary T.S. Schaffer, (Banff: Whyte Museum of the Canadian Rockies, 2014).

Ryan, Maureen. "Picturing Canada's Native Landscape: Colonial Expansion, National Identity, and the Image of a Dying Race." RACAR 17 (1990).

Sassoon, Joanna. "Photographic Materiality in the Age of Digital Reproduction." In Photographs Object Histories, edited by Elizabeth Edwards and Janice Hart, 196213. New York: Rutledge, 2004.

Schwartz, Joan M. "Coming to Terms with Photographs: Descriptive Standards, Linguistic 'Othering,' and the Margins of Archivy." Archivaria 54 (2002): 142171.

Schwartz, Joan M. and Terry Cook. "Archives, Records, and Power: The Making of Modern Memory.” Archival Science 2 (2002): 1-19.

Silversides, Brock V., Face Pullers: Photographing Native Canadians 1871-1939, (Saskatoon, SK.: Fifth House, 1994). 
Skidmore, Colleen ed. This Wild Spirit: Women in the Rocky Mountains of Canada. Edmonton: University of Alberta Press, 2006.

Smith, Linda Tuhiwai. Decolonizing Methodologies. New York: Zed Books, 1999.

Snow, John. These Mountains Are Our Sacred Places: The Story of the Stoney People. Calgary: Fifth House, 2005.

Sontag, Susan. “In Plato’s Cave.” In On Photography, 3-24. New York: Farrar, Straus and Giroux, 1977.

Stoler, Ann Laura. "Colonial Archives and the Arts of Governance," Archival Science 2 (2002): 87.

Taylor, Colin F. and Hugh Dempsey. With Eagle Tail: Arnold Lupson and 30 Years Among the Sarcee, Blackfoot, and Stoney Indians on the North American Plains. Toronto: Keyporter Books, 1999.

Thomas, Jeff. "Emergence from the Shadow: First Peoples' Photographic Perspectives." In The Cultural Work of Photography in Canada. Edited by Andrea Kunard and Carol Payne, 212-228. Montreal \& Kingston: Queens University Press, 2011.

Tippecanoe County Historical Association, "Advertising Fans," http://web.ics.purdue.edu/ salvo/@SEA/exhibit/advertising.asp, last modified 2008.

Touchie, Rodger D. Edward S. Curtis Above the Medicine Line: Portraits od Aboriginal Life in the Canadian West. Vancouver, Victoria, Calgary: Heritage House, 2010.

Tsinhnajinnie, Hulleah J. "When Is a Photograph Worth a Thousand Words?" In Photography's Other Histories, edited by Christopher Pinney, 40-52. Durham: Duke University Press, 2003.

Valverde Valdés, María Fernanda. Photographic Negatives: Nature and Evolution of Processes. Rochester. NY: Advanced Residency Program in Photograph Conservation, 2005.

Vizenor, Gerald. Manifest Manners: Narratives on Postindian Survivance. Lincoln and London: University of Nebraska Press, 1994.

Whyte, Jon. Indians in the Rockies. Banff: Altitude Publishing, 1985.

Williams, Carol. Framing the West: Race, Gender, and the Photographic Frontier in the Pacific Northwest. New York: Oxford University Press, 2003. 